\title{
Supermarket contracts and household welfare in the small farm sector: Panel data evidence from Kenya
}

\author{
Dissertation \\ to obtain the Ph.D. degree \\ in the International Ph.D. Program for Agricultural Sciences in Göttingen \\ (IPAG) \\ at the Faculty of Agricultural Sciences, \\ Georg-August University of Goettingen, Germany

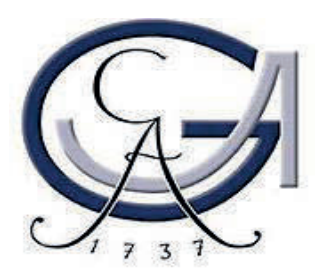 \\ presented by \\ Dennis Otieno Ochieng \\ born in Migori, Kenya
}

Göttingen, March 2017 
D7

1. Name of supervisor: Prof. Dr. Matin Qaim

2. Name of co-supervisor: Prof. Dr. Bernhard Brümmer

3. Member of Examination Committee: Prof. Dr. Ludwig Theuvsen Date of dissertation: 16 March, 2017 


\section{Summary}

In many developing countries, the food retail sector is rapidly modernizing. With rising urban middle classes, supermarkets are increasingly replacing wet markets and other traditional retail outlets as the preferred place of food purchases. These shifts in the food retail sector also have implications for agricultural supply chains. While in smaller towns supermarkets primarily focus on the sales of processed foods, in larger cities they offer their customers a variety of fresh fruits and vegetables. In order to manage regular supply of fresh and highquality produce, supermarkets often do not rely on wholesale markets alone but also contract farmers directly. In many countries, such supermarket contracts also involve smallholder farmers.

The existing literature shows that the rapid expansion of supermarkets in developing countries can provide interesting new marketing opportunities for smallholder farmers. Smallholder farmers, who make up the majority of the rural poor, can benefit from supplying supermarkets through higher and more stable prices, as well as better access to information and technology. Hence, the expansion of supermarkets may potentially contribute to poverty reduction and rural development. However, available impact studies show mixed results. While a few studies confirm positive effects of supermarket contracting on farm productivity and household incomes in the small farm sector, others find that marginalized farms are unable to participate in supermarket channels due to technical, financial, or other types of constraints. Smallholder farmers who manage to overcome these constraints often benefit significantly. However, their participation in supermarket contracts is dynamic, with high drop-out rates observed over time.

Against this background, this dissertation entails two essays that cover two key questions (i) what types of supermarket contracts do smallholder farmers prefer? And (ii) what are the effects of smallholder participation in supermarket channels on household income and diets? For the first question, inclusion and successful participation of smallholders seem to depend on contractual design. This is difficult to analyze based on observational data alone, because variations in contractual design rarely occur in the same setting. In the second chapter of this dissertation, we address this research and knowledge gap using a choice experiment that we carried out with smallholder farmers in Kenya in 2015. For the second question, one shortcoming of the existing research is that most studies used cross-sectional data, making the 
identification of causal effects difficult. A few studies used panel data, but only looked at purely economic effects. We contribute to the literature by using two rounds of panel data to examine the effects of smallholder participation in supermarket channel on household income and diets as elucidated in the third chapter of this dissertation.

Addressing the two knowledge gaps would be beneficial in understanding the types of contracts that facilitate smallholder participation in such high value channels as supermarkets, and in unravelling the welfare effects of supermarket contracting on farm households in terms of income and diets. Recent statistics show that 800 million people suffer from hunger and another 2 billion suffer from micronutrient malnutrition. The prevalence of undernourishment and micronutrient malnutrition is high among the rural populations that are also largely smallholder farmers. Hence, our study is relevant in the context of assessing the welfare effects of supermarket contracting on smallholder farmers. We focus on supermarket contracts with smallholders in Kenya as one of the countries with the fastest growth of supermarkets in Sub-Saharan Africa. Currently, supermarkets accounts for $10 \%$ of national grocery sales in Kenya and the share is projected to grow with increased urbanization.

The first essay in chapter two entails a discussion of the choice experiment results on vegetable farmers' preferences for supermarket contracts. We used D-optimal design to design the choice cards where we varied design attributes of contracts with supermarkets and other traders to examine farmers' contractual preferences and how they vary with socioeconomic characteristics. The five attributes included were; output price for the vegetables sold, place of sale, form of sale, timing of sale, and payment mode. We then specified and estimated mixed logit models to account for preference heterogeneity and finally calculated farmers' willingness to accept (WTA) output price changes for certain contract attributes.

The results show that farmers generally prefer supplying traditional marketing channels without a contract. Farmers that currently supply traditional channels are more contract-averse than either the current or previous supermarket suppliers. Farmers that recently entered the supermarket channel have significantly more positive attitudes towards contracting. The results further underscore the importance of contract transparency, and trust between farmers and buyers. Supermarkets contracts usually involve delayed payments but this has evolved over time from payment based on quantities delivered to payments based on actual sales to consumers, without a proper monitoring mechanism. This involves different types of risk. The 
results indicate that farmers would accept significantly lower prices if they were either paid based on quantities delivered or if they had an option to verify actual customer sales. Farmers' contractual preferences are also influenced by socioeconomic variables such as age and level of education of household head, and income levels.

The second essay in chapter 3 discusses the effects of supermarket contracting on household income and diets. We focus on household dietary diversity, consumption of calories, zinc, iron, and vitamin A as dietary indicators. Data on household food consumption were collected using 7-day recalls and conversion made using food conversion tables for Kenya. We estimated fixed effects and random effects models for panel data analysis. The results show that supplying supermarkets has increased farm household income by $66 \%$. Supermarket contracts also contribute to higher levels of dietary diversity, calorie consumption and zinc consumption. We do not find significant effects on vitamin A and iron consumption. Using the estimated dietary effects for simple simulations suggests that wider participation of farmers in supermarket channels could help to reduce the prevalence of undernourishment by $8 \%$ and zinc deficiency by $12 \%$.

The final chapter of this dissertation concludes by presenting a summary of the key findings and the policy implications, limitations of the study and suggestions for future research. We conclude that designing contracts with; lower transaction costs, more transparent quality grading system, sales verification mechanisms, and fairer risk-sharing arrangements could enhance smallholder participation in supermarket channels and other emerging high-value markets. Group marketing by farmers could be an interesting option to reduce individual risks and transaction costs. Infrastructural and institutional improvements could also facilitate smallholder access to high-value markets. Further, supplying supermarket channels increases household incomes and improves diets. In summary, smallholder participation in high value chains such as supermarkets is worthwhile and efforts towards facilitating their engagement would not only contribute to poverty reduction, but also to more economic and social sustainability of high value chains in an environment where smallholders dominate agricultural production. 


\section{Acknowledgements}

Thanks to the Almighty God for His grace, provisions and wisdom endures forever. Doctoral study is like taking a journey to the unknown, trying to provide new insights on topics most researched and from which numerous conclusions continue to trickle by the day, and to answer the dreaded question - what is the novelty of your work? I must therefore thank some individuals who have contributed to lessening the burden of this question.

I sincerely thank Prof. Dr. Matin Qaim, my supervisor and mentor throughout the study program. I am grateful for his contribution to shaping my scholarly outlook through the intense thought-provoking meetings we had to convert the penned ideas into novel research objectives. May his scholarly cup overflow in the academic endeavors. Special thanks to Dr. Prakashan Veettil who took his time from a busy schedule to assist in designing the choice experiment. I also acknowledge the contribution of my thesis committee members, Prof. Dr. Bernhard Brümmer and Prof. Dr. Ludwig Theuvsen.

This work would not have been carried out more calmly without the support of my loving wife Emma Vivian, my children, mother Margaret Ochieng, and sisters who encouraged me throughout the process. These people endured long periods of my physical absence in their lives but I found their unconditional love and gratuitous patience worthy.

To the GlobalFood fraternity and chair of International Food Economics and Rural Development group members, I am grateful for your unwavering support throughout the years. Special thanks to Kathrin Demmler who made my years in Goettingen enjoyable, and from whom my nutrition knowledge accumulated immensely. To Eva-Marie Meemken and Esther Gehrke, thanks for the insightful office discussions. I must also acknowledge Justus, Sylvester, Priscilla, Ken, Haruna and Rosina, colleagues and friends whose critiques I considered gracefully in the scholarly "bashing" sessions. I sincerely treasured those meetings that broadened my intellectual horizon. Special thanks to my predecessors, Dr. James Rao and Dr. Christine Chege for conducting previous survey rounds.

Scholarship offers are very competitive and therefore I duly acknowledge the significant financial support from the African Economic Research Consortium (AERC) and the German Research Foundation (DFG) through the GlobalFood Program (RTG 1666) that made my study possible. The study program also involved coursework and therefore I thank all the 
course instructors for their insightful contributions especially the soft skills courses, for it is tragic to be a scholar without soft skills.

I am indebted to Lutz Depenbusch, the extension officers, community leaders, farmer group leaders, enumerators, and field supervisors for their support during reconnaissance and farm surveys. I gratefully acknowledge the farmers for their time during the lengthy interviews, efforts in overcoming challenges of smallholder farming, and resolve to participate in high value markets. These efforts are worthy of our attention as researchers and may we remain true to that calling. I also thank the anonymous reviewers of our manuscript for their insightful reviews that enriched the quality of our article published in journal "Food Policy".

Finally, the views in this dissertation are my own and penned to the best of my knowledge as a contribution to the knowledge gap on the contract farming literature. Hence, they neither reflect positions of the aforementioned financiers nor Georg-August University of Goettingen with which I am affiliated as a research associate. 


\section{Table of Contents}

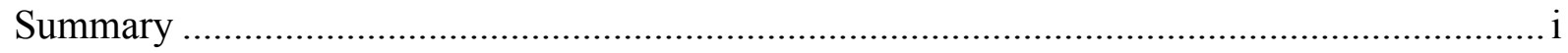

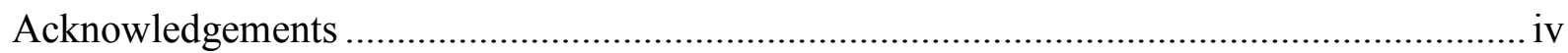

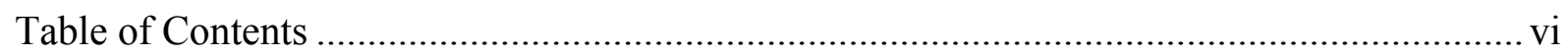

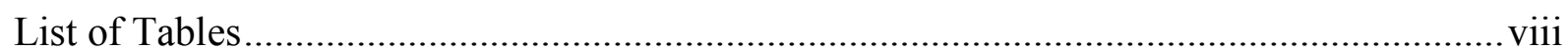

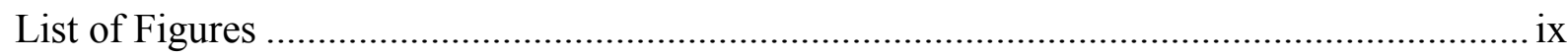

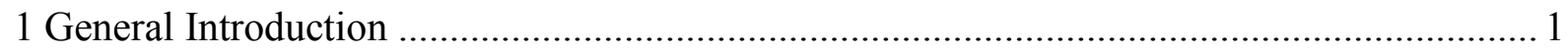

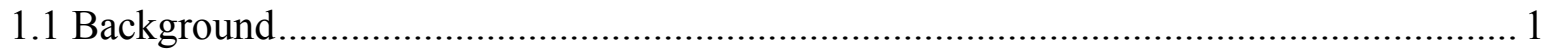

1.2 Research Problem and Objectives ……………………........................................ 3

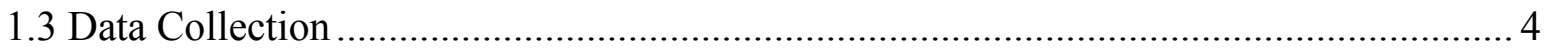

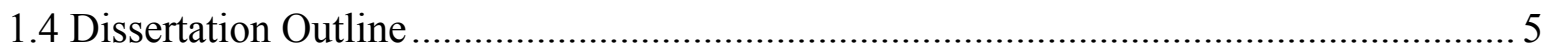

2 Farmers' Preferences for Supermarket Contracts in Kenya ................................................. 6

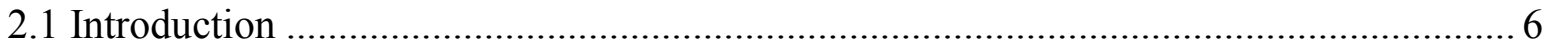

2.2 Supermarket Contracts in Kenya ................................................................................

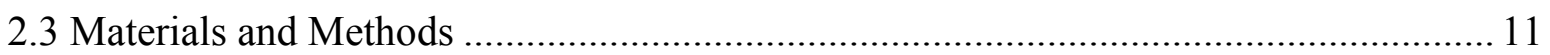

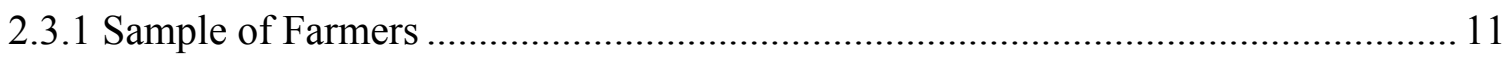

2.3.2 Choice Experimental Approach ........................................................................ 13

2.3.3 Contract Design Attributes .................................................................................. 14

2.3.4 Estimation Procedure ......................................................................................... 17

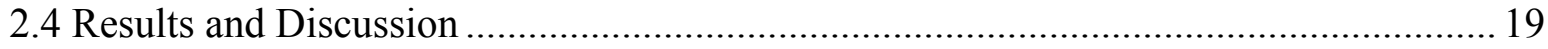

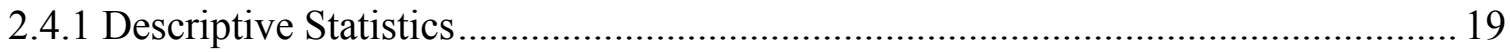

2.4.2 Farmers' Preferences for Contracts and Contract Attributes .................................. 20

2.4.3 The Role of Socioeconomic Characteristics ............................................................. 22

2.4.4 Farmers' Willingness to Accept........................................................................... 28

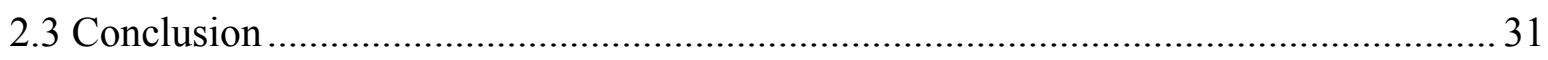

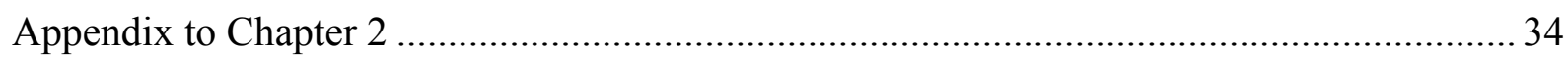


3 Supermarket Contracts, Income, and Changing Diets of Farm Households: Panel Data

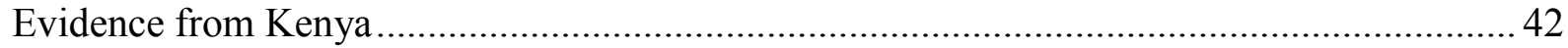

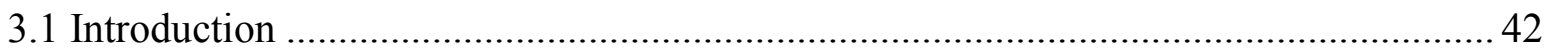

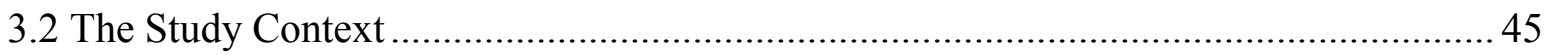

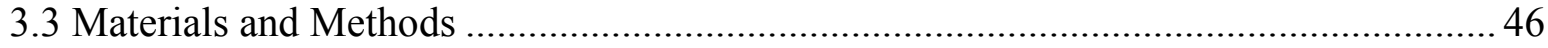

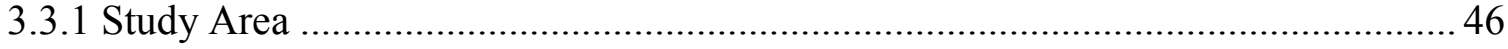

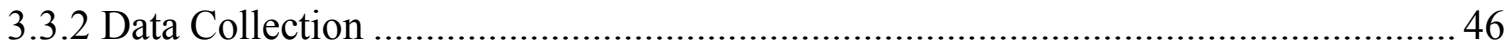

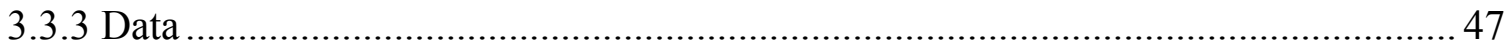

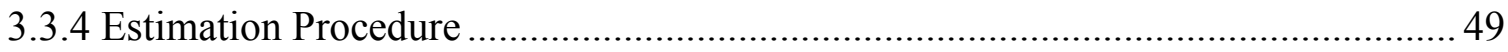

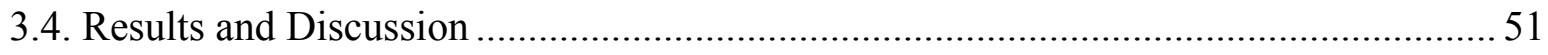

3.4.1 Farm and Household Characteristics ................................................................ 51

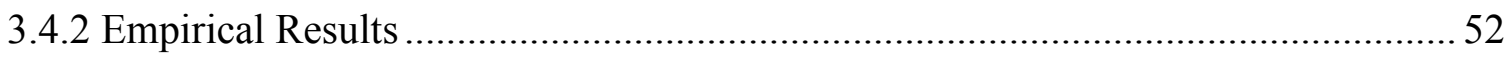

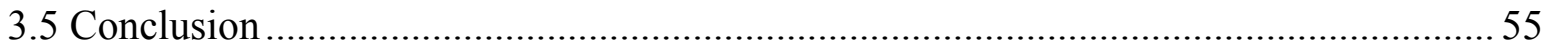

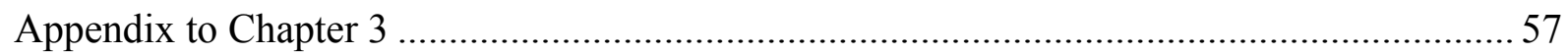

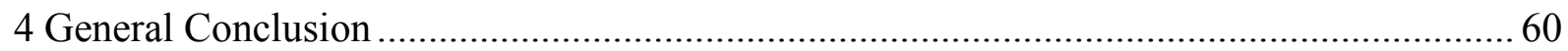

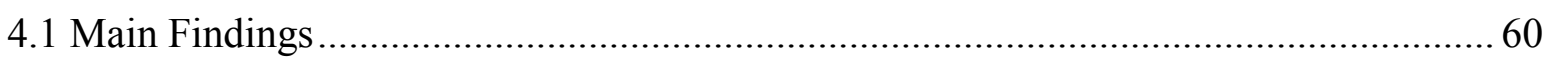

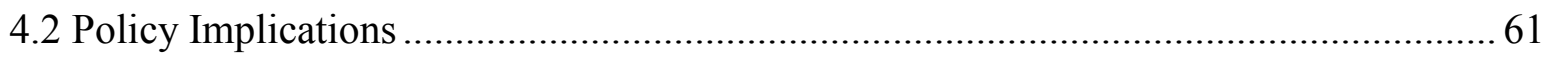

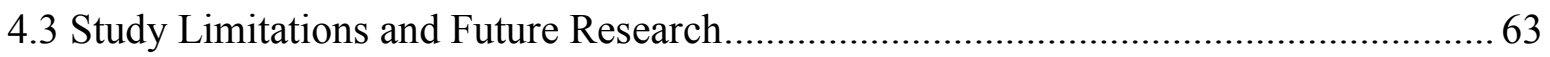

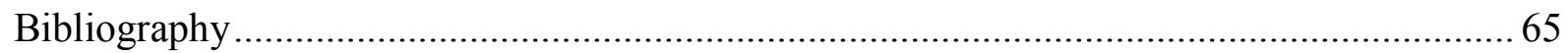

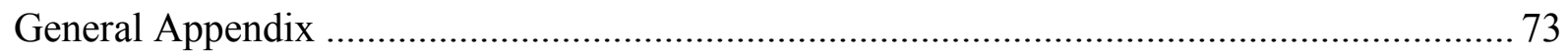

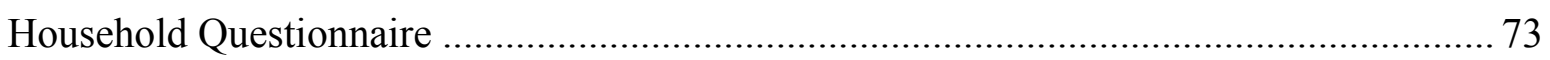

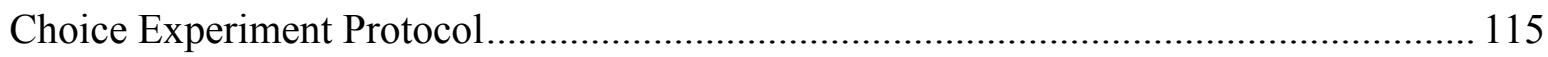

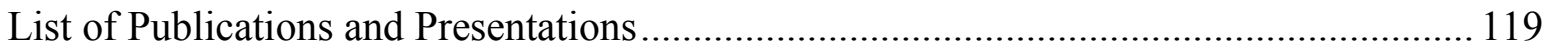

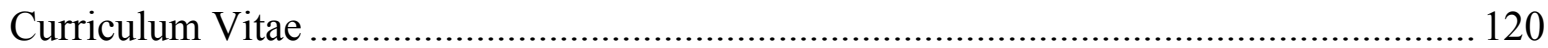




\section{List of Tables}

Table 2. 1 Contract attributes and attribute levels.

Table 2. 2 Summary statistics of selected socioeconomic variables (2015) ........................... 20

Table 2. 3 Mixed logit model estimates of farmers' general preferences for contracts .

Table 2. 4 Estimates of the influence of contracting history and socioeconomic characteristics on farmers' preferences for contracts 24

Table 2. 5 Mixed logit models with interactions between contract attributes and socioeconomic characteristics 27

Table 2. 6 Mean willingness to accept (WTA) different contract attribute levels .................. 28

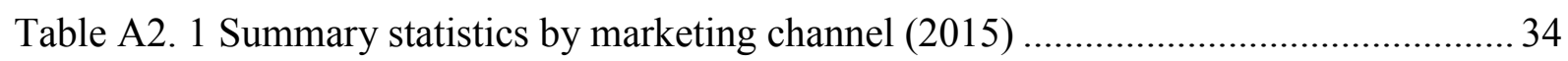

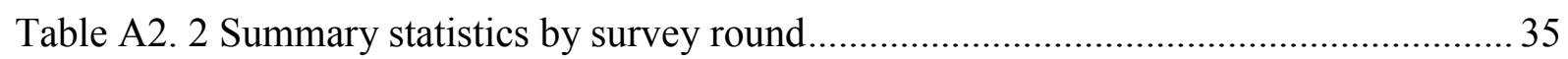

Table A2. 3 Summary statistics for farmers with different contracting history (2015) .......... 36

Table A2. 4 Mixed logit models with interactions between payment mode attributes and farmers' contracting history .

Table A2. 5 Mixed logit models with interactions between contract attributes and socioeconomic characteristics for SM farmers

Table A2. 6 Mixed logit models with interactions between contract attributes and

socioeconomic characteristics for TC farmers 40

Table 3. 1 Number of farm households interviewed in three survey rounds in Kenya .47

Table 3. 2 Characteristics of the farmers (pooled sample). 51

Table 3. 3 Nutrition indicators by marketing channels 52

Table 3. 4 Supermarket contracting and household income .53

Table 3. 5 Supermarket contracting and household diets. 54

Table A3. 1 Supermarket contracting and HDDS 2 -Robustness check .57

Table A3. 2 Supermarket contracting and dietary outcomes .58

Table A3. 3 Fixed effects models for dietary outcomes. 59 


\section{List of Figures}

Figure 2. 1. Number of farmers supplying supermarkets and traditional channels (2008-2015) 12

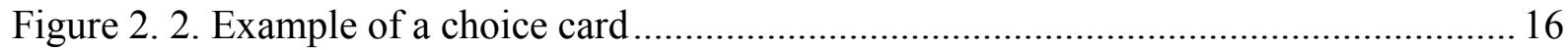




\section{General Introduction}

\subsection{Background}

Globalization has expanded trade in fresh and processed foods across countries, courtesy of trade liberalization policies by various countries in the past few decades (Swinnen et al., 2011). Increased trade has also resulted in food safety and quality concerns particularly in developed countries (Unnevehr, 2000; Codron et al., 2005; Swinnen et al., 2015). Consequently, numerous public and private food safety and quality standards have emerged to govern food trade, with far-reaching implications in the food marketing systems worldwide (Jaffee and Masakure, 2005; Okello and Swinnton, 2007; Asfaw et al., 2009). Another striking consequence is the globalization of agri-food systems, the increased integration of food value chains, and the remarkable spread of supermarkets in many developing countries in Central America, Asia, and Africa (Berdegué and Balsevich, 2005; Traill, 2006; Reardon et al., 2012).

In some developing countries, supermarkets are gradually replacing traditional markets as preferred shopping points particularly for fresh fruit and vegetables (FFVs). This is occasioned by rapid urbanization, rising incomes and middle classes, and changes in taste and preferences of consumers that also value convenience (Reardon et al., 2003; Richie et al., 2015; Tschirley et al., 2015; Qaim, 2017). Population that is more affluent also view fresh foods sold in supermarkets as better in terms of safety and quality. The welfare impacts of the supermarket growth in developing countries have been analyzed in two broad perspectives. One strand of literature focuses on supermarkets' contribution to the nutrition transition in developing countries through consumer purchases of diverse and relatively cheaper foods (Asfaw, 2008; Popkin et al., 2012; Popkin, 2014; Kimenju et al., 2015; Umberger et al., 2015).

Another strand of literature concentrates on how supermarket growth has contributed to economic welfare of smallholder farmers that are contracted by supermarkets for the supply of fresh produce. Our study contributes to the latter strand of literature. Existing studies have analyzed the drivers of smallholder participation in high-value channels including supermarkets (Reardon et al., 2003; Codron et al., 2004; Traill, 2006). Findings show that resource constrained smallholder farmers may be excluded from high-value channels due to stringent consistency, quality, timeliness, and volumetric requirements exerted by 
supermarkets as an example (Berdegué et al., 2005; Hernández et al., 2007; Andersson et al., 2015).

Supplying supermarket channels require substantial on-farm investment in modern technologies (e.g. seeds, crop chemicals, and irrigation) and post-harvest handling equipment to fulfil contractual obligations. For smallholders, access to these inputs and technologies also hinges on access to credit which is limited in many developing countries (Narayanana and Gulati, 2002; Giné and Yang, 2009). Hence, smallholder access to markets is impeded by institutional failures and market imperfections that lead to high transportation and transaction costs, aspects that are evident in high-value chains (Alene et al., 2008; Escobal et al., 2012).

The types of contracts offered to farmers may also influence participation in contractual arrangements. Contracts usually involve delayed payments, which may be a problem to cashstrapped households that require cash proceeds for income and consumption smoothing (Rosenzweig and Wolpin, 1993). Depending on the context, contracts could also unfavorably shift substantial marketing risks to farmers thereby impeding participation in high value channels (Abebe et al., 2013; Ochieng et al., 2017).

Smallholder farmers that overcome the hurdles benefit significantly from supplying high value chains. Studies have shown various positive welfare effects of contracting with supermarkets on crop productivity and smallholder investment in modern farm technologies (Berdegué et al., 2005; Neven et al., 2009; Rao et al., 2012). This leads to greater production capacities to consistently supply high-value channels. Supplying supermarkets has also generated on-farm and off-farm labor employment (Neven et al., 2009; Rao and Qaim, 2013). In the case of labor intensive crops, labor-constrained households often hire extra labor to supplement family labor. Such employment opportunities provide incomes that stimulate growth of the rural economy, given that the bulk of expenditures of rural folks are on food and basic non-luxuries largely produced locally (Hazel et al., 2010; Wiggins et al., 2010).

Supplying supermarkets also increases farm profits and overall household income (Balsevich et al., 2003; Rao and Qaim, 2011; Chege et al., 2015). This stems from higher and more stable prices together with market assurance, aspects that can all contribute to further increase farm investment (Eaton and Shepherd, 2001). For rural farm households, a high proportion of their income is spent on food (Alston et al., 1995). Studies show that higher household incomes facilitate improved household dietary diversity (quality) through access to diverse nutritious 
foods as well as micronutrients intake (von Braun., 1994; Chege et al., 2015). This is more pronounced in cases of well-functioning food markets (Jones et al., 2014).

Nutrition effects of supermarket contracting should be interpreted with caution because it is context specific and depends on the type of contracted crop, which may result in changes in gender roles in the marketing of the crops and use of sales proceeds. Studies show that in some cases, as crops that were considered "women's crops" increasingly get commercialized, men take over control of revenues (von Braun, 1994; Fischer and Qaim, 2012), much to the detriment of household nutrition (Chege et al., 2015). Against this background, this dissertation presents findings from our study that covers two broad objectives highlighted below.

\subsection{Research Problem and Objectives}

In spite of the extant literature on the positive welfare effects of supermarket contracting on smallholder farm households, smallholder participation in supermarket channel remains limited and dynamic with high drop-out rates observed. This could be partly attributed to the contract design. However, little is known about farmers' preferences for supermarket contracts and design attributes. Also, many studies that analyze the welfare effects of smallholder participation in supermarket channels use cross-section data (Berdegué et al., 2005; Miyata et al., 2009; Neven et al., 2009; Rao and Qaim, 2011; Chege et al., 2015) that is plagued with endogeneity issues, making it difficult to draw causal inferences. A few panel data studies (that reduce problems with unobserved heterogeneity) largely focus on economic welfare alone (Michelson, 2013; Andersson et al., 2015). Except for Chege et al (2015), hardly any study has analyzed the effect of supplying supermarkets on farm household nutrition or diets, and the work by Chege et al (2015) is based on cross-section data only.

This dissertation, which comprises two substantive essays, addresses the knowledge gaps about contractual design, farmers' preferences for contracts, and broader welfare effects of supermarkets in the small farm sector. In the first essay, we use choice experimental data collected from a sample of vegetable farmers in Central Kenya to assess farmers' preferences for contracts and contract design attributes. These important aspects illuminate the reasons for dynamic participation in high-value channels involving marketing contracts. In the second essay, we use panel data models (fixed effects and random effects) to examine the association 
between supplying supermarkets and farm household income and diets. This is also important, given the high prevalence of undernourishment and micronutrients malnutrition in developing countries that largely affect poor farm households.

Considering the participation dynamics in the supermarket channel as observed over the years, it is important to understand the underlying problems with the existing contractual arrangements, and the households' welfare implications of supplying supermarkets over time. The broad objectives of the study are to analyze smallholder farmers' preference for supermarket contracts in Kenya and to examine the effects of contracting on farmers' incomes and household diets. The dietary indicators used are; household dietary diversity and quantities of calories and micronutrients (zinc, iron and vitamin A) consumed per adult equivalent and day. The specific objectives are as follows:

1 To analyze farmers' preferences for supermarket contracts in general,

2 To analyze farmers' preferences for contract design attributes,

3 To analyze the effects of supermarket contracting on household income, and

4 To analyze the effects of supermarket contracting on household diets.

\subsection{Data Collection}

The aforementioned objectives are analyzed using panel data collected over several years. Multi-stage sampling procedure was used in 2008 to sample 402 vegetable farmers from 4 main vegetable producing divisions of the former Kiambu District (Rao and Qaim, 2011). From the 4 divisions, 31 locations were purposely selected using information on vegetable production from the former Kiambu District agricultural office. Farmers were then selected from each of the locations using simple random sampling procedure. A follow-up survey was conducted in 2012 with few replacements. In total, 384 farmers were surveyed in 2012 (Chege et al., 2015). Another follow-up survey was conducted with few replacements in 2015, whereby 409 farmers were sampled (Ochieng et al., 2015).

Regarding my role in the data collection process, I conducted the third round of survey in 2015, where in addition to the 2012 questionnaire, I designed and implemented a choice experiment to analyze the first two objectives on farmers' preferences for supermarket contracts. The extended questionnaire and choice experiment protocol are in the general appendix of this dissertation. The 2008 data are combined with those of subsequent survey 
rounds to analyze the effects of supermarket participation on household income in a panel regression framework (objective 3). It should be noted that dietary related data were only collected in 2012 and 2015 survey rounds. Hence, objective 4 is analyzed using only 2012 and 2015 data.

\subsection{Dissertation Outline}

The rest of the dissertation is as follows. Chapter 2 presents an essay on farmers' preferences for supermarket contracts where the results for the choice experiment are discussed (the first two objectives). This is followed by chapter 3 that discusses the effects of supermarket contracting on household income and diets (the last two objectives). Chapter 4 presents the general conclusion by summarizing the main findings, policy implications, limitations of the study, and suggestions for future research. 


\title{
2 Farmers' Preferences for Supermarket Contracts in Kenya ${ }^{1}$
}

\begin{abstract}
With the modernization of global agri-food systems, the role of contract farming increases. This also involves smallholder farmers in developing countries. While previous studies have looked at economic impacts of contract schemes on smallholder farmers, little is known about farmers' preferences for contracting in general, and for specific contract design attributes in particular. Better understanding farmers' preferences and constraints is important to make smallholder contract schemes more viable and beneficial. This article builds on a choice experiment to analyze farmers' preferences and preference heterogeneity for contracts in Kenya. In the study region, supermarkets use contracts to source fresh vegetables directly from preferred suppliers. However, farmer dropout rates are high. Mixed logit models are estimated to examine farmers' attitudes towards critical contract design attributes. Having to deliver their harvest to urban supermarkets is costly; hence farmers require a significant output price premium. Farmers also dislike delayed payments that are commonplace in contract schemes. The most problematic contract attribute is related to unpredictable product rejection rates, substantially adding to farmers' risk. Designing contracts with lower transaction costs, more transparent quality grading, and fairer risk-sharing arrangements could enhance smallholder participation in supermarket procurement channels.
\end{abstract}

\subsection{Introduction}

With the modernization of global agri-food systems, the role of contract farming increases (Wang et al., 2014; Otsuka et al., 2016). This also involves farmers in developing countries. Export or processing companies often source agricultural products through outgrower schemes, in order to ensure consistent and high-quality supply (Barrett et al., 2012; Dedehouanou et al., 2013; Rosch and Ortega, 2014; Bellemare and Novak, 2016). Also in domestic supply chains in developing countries, the role of contracting increases. Rising urban middle classes have higher preferences for food quality and convenience. As a result,

\footnotetext{
${ }^{1}$ This chapter was published as: Ochieng, D.O., Veettil, P.C., Qaim, M., 2017. Farmers' preferences for supermarket contracts in Kenya. Food Policy 68, 100-111.
} 
modern supermarkets are gaining market shares in retailing (Reardon and Timmer, 2014; Rischke et al., 2015). Especially for fresh and perishable products, supermarkets often do not rely on traditional wholesale markets but procure directly from farmers through contracts (Rao et al., 2011; Michelson et al., 2012; Trebbin, 2014).

Contract farming arrangements in general, and supermarket contracts in particular, can provide new marketing opportunities for smallholder farmers in developing countries. Contracted smallholders may benefit from higher and more stable prices, as well as better access to inputs, technology, and information (Berdegué et al., 2005; Sartorius and Kirsten, 2007; Blandon et al., 2009a; Barrett et al., 2012; Reardon and Timmer, 2014). Indeed, recent studies showed that supermarket contracts have contributed to higher farm productivity and household welfare in some smallholder situations (Minten et al., 2009; Rao and Qaim, 2011; Rao et al., 2012; Michelson, 2013; Chege et al., 2015). However, studies also showed that smallholders are sometimes unable to participate in supermarket channels (Hernández et al., 2007; Neven et al., 2009), or they drop out of contracts for reasons that are not always entirely clear (Andersson et al., 2015). To some extent, the inability to participate can be explained by lack of human and financial capital. But unfavorable contract design may also play an important role (Schipmann and Qaim, 2011; Otsuka et al., 2016). Better adjusting contract design to the particular needs and constraints could help to make contract farming more viable for smallholders.

Relatively little is known about how variations in contract design affect smallholder participation and socioeconomic impacts. This is difficult to analyze with purely observational data, because variations in contract design rarely occur in the same setting. A few recent studies used randomized field experiments to analyze effects of changing contract design in existing schemes (Saenger et al., 2013; Saenger et al., 2014). Field experiments are costly, so implementing a larger number of experimental treatments - which would be required to evaluate changes in multiple contract design attributes - is hardly possible.

Choice experiments are less costly to implement than field experiments and have been used in recent studies to analyze smallholder preferences for contracts and particular contract terms and provisions. These studies evaluated preferences for hypothetical contract attributes related to output price and quality levels, the need for upfront investments, and the provision of training, credit, and inputs through the contracting company, among others (Blandon et al., 2009b; Schipmann and Qaim, 2011; Bellemare, 2012; Abebe et al., 2013). None of these 
studies looked at supermarket contracts, which often differ from those of export or processing companies. For instance, due to higher food quality and food safety standards in export markets, contracts in the export sector often involve strict regulations on the type of production technology to use (Okello and Swinton, 2007; Asfaw et al., 2010; Maertens et al., 2012).

As part of the contracts, export and processing companies sometimes also provide credit, inputs, and extension services to farmers. In those cases, farmers are usually not allowed to side-sell their harvest to other buyers (Rosch and Ortega, 2014). Contracts with domestic supermarkets are often less stringent on production technology. Inputs and credit are rarely provided, so that side-selling is usually not prohibited (Hernandez et al., 2007; Minten et al., 2009; Rao and Qaim, 2011). These differences may affect farmers' willingness and ability to participate in contract schemes.

We add to the literature by analyzing farmers' preferences for supermarket contracts in Kenya, using data from a choice experiment. We specifically look at a sample of smallholder vegetable producers that was surveyed over many years. Some of these farmers supply vegetables to supermarkets under contract while others sell their vegetables in traditional spot markets. Some farmers in the sample also had a supermarket contract in the past, but decided to switch back to supplying traditional markets. We hypothesize that the low rates of contract participation may be related to certain contract terms and provisions that are difficult to meet or simply disliked by farmers. This is tested by examining farmers' marketing choices with hypothetical variations in contract design.

We also analyze the relative importance of different contract attributes by computing farmers' willingness to accept for each attribute level. Mixed logit models are estimated to account for preference heterogeneity. Choice experiments, like other approaches used to elicit stated preferences, are often associated with hypothetical bias (Hensher et al., 2005). Building on a sample of farmers with actual contract experience and using variations from existing contracts increases the level of realism in our experiment and may therefore help to reduce such bias. 


\subsection{Supermarket Contracts in Kenya}

Kenya ranks second after South Africa in terms of growth and expansion of supermarkets in Sub-Saharan Africa (Planet Retail, 2016). Supermarkets account for about 10\% of total food retailing in Kenya with a growing trend. In Nairobi and other big cities, the supermarket share is already much higher (Chege et al., 2015). As in other developing countries (Reardon and Timmer, 2014), modern supermarkets in Kenya started their business in major cities but more recently opened stores in smaller towns as well (Rischke et al., 2015). The most widespread supermarket chains in Kenya include Nakumatt, Uchumi, Tuskys, Naivas, and Ukwala, all of which are Kenyan owned. The spread of foreign-owned supermarket chains in Kenya has been limited up till now (Planet Retail, 2016).

Supermarket stores in smaller towns so far primarily sell processed foodstuffs. Many of the stores in bigger cities also have a large fresh food section, where a variety of fruits and vegetables is sold. Urban consumers often associate fruits and vegetables bought in modern supermarkets with higher quality, food safety, and freshness than products bought in traditional markets. On average, fresh products are also more expensive in supermarkets than in traditional markets. Supermarkets tend to place much emphasis on consistent supply and good outward appearance of fresh fruits and vegetables. As traditional wholesale markets are not sufficiently reliable in this respect, many of the fresh products are procured directly from farmers through contractual arrangements (Neven et al., 2009). Typically, farmers have to deliver their harvest directly to the supermarket stores. The produce has to be cleaned by farmers before delivery; leafy vegetables also have to be sorted and bundled ready for supermarket shelves (Rao and Qaim, 2013). Supermarket procurement officers occasionally visit contracted farmers to inspect production and post-harvest handling activities.

This study focuses on farmers in Kiambu County, Central Kenya, not far from the capital city of Nairobi. These farmers have a long tradition of growing vegetables, notably green leafy ones (kale etc.) for the domestic market. Some of the farmers have marketing contracts with supermarkets in Nairobi whereas others sell the same type of vegetables in traditional markets, mostly to traders at the farm gate or in the village. Contracts only refer to the sales of vegetables and do not involve any provision of credit or inputs. Contracts stipulate the quantity of vegetables that a farmer has to deliver to a particular supermarket store on specified dates (Rao and Qaim, 2011). Farmers who are unable to deliver as scheduled are subsequently struck off the list of preferred suppliers and lose their contract. 
Beyond the quantities agreed, contracted farmers can sell their vegetables in traditional markets. However, as farmers in Kiambu are small-scale producers, they rarely have significant excess quantities. In other words, contracted farmers sell most of their vegetables to supermarkets (Chege et al., 2015). Sometimes, they even collect vegetables from neighboring farms in order to meet the agreed quantities. The average quantity of vegetables sold per transaction is relatively small and does not differ much between supermarket and traditional marketing channels. However, in supermarket channels the frequency of transactions tends to be higher and deliveries have to be made on specified dates. Payments for vegetables delivered to supermarkets are delayed by one or two weeks. In traditional markets, farmers can sell whenever they want, and buyers pay immediately.

The prices for vegetables sold to supermarkets are higher and more stable than those typically obtained in traditional markets, which is why supermarket contracts are attractive for farmers (Rao and Qaim, 2011). In principle, any farmer can get a contract when he/she is able to supply certain quantities on a regular basis and deliver to the supermarket stores in Nairobi. Meeting these conditions is easier for farmers with advanced irrigation equipment and good access to public or private transportation (Rao et al., 2012). Most of the contracts are made between supermarkets and individual farmers, but in some cases farmer groups are also contracted. Collective action can help farmers to coordinate their supplies and reduce transportation and transaction costs.

As mentioned, farmers lose their contract when they are unable to deliver the agreed quantities to supermarkets according to schedule. Contracted farmers, on the other hand, sometimes complain about longer-than-expected payment delays or quantities rejected by supermarkets due to issues with product freshness or cleanliness (Andersson et al., 2015). In the contracts, specifications about product quality remain relatively vague.

The contracts do not differ systematically between different supermarket chains. However, contractual details have evolved over time. We have observed contractual arrangements between supermarkets and farmers in Kiambu since 2008. In the beginning, contracted farmers had fixed delivery dates. In subsequent years, supermarkets have gradually shifted away from a fixed schedule towards placing orders with contracted farmers through phone calls a few days prior to required delivery. Furthermore, the payment mode has changed. 
Initially farmers were paid for the actual quantities of vegetables delivered to supermarkets. Quantities not meeting the quality requirements were rejected, but this was a relatively predictable process. Rejected quantities could then be sold in traditional markets. More recently, farmers are no longer paid for the quantities delivered, but for the quantity the supermarket was able to sell to its customers. This means that most of the supermarket's marketing risk is transferred to farmers. Quantities not sold by supermarkets can be traced back to individual farmers through small color codes on the vegetable bundles. Farmers can take the unsold quantities back if they wish, but this requires additional tours to the supermarket stores to pick up withered vegetables that can hardly be sold elsewhere.

In spite of these changes, participation in supermarket contracts was shown to remain economically beneficial for farmers in Kiambu (Andersson et al., 2015). Nevertheless, deteriorating contractual terms may be one reason for the high dropout rates observed. As will be shown below, many farmers who had supermarket contracts in the past reverted to the traditional market. Focus group discussions revealed that this was often based on the farmers' own decisions rather than losing contracts unintentionally. Our choice experiment builds on these existing and evolving contracts to better understand farmers' preferences and constraints.

\subsection{Materials and Methods}

\subsubsection{Sample of Farmers}

This study builds on a sample of vegetable farmers from Kiambu County, Central Kenya. The sample was selected in 2008 through a stratified random sampling procedure (Rao and Qaim, 2011; Rao et al., 2012). Supermarket (SM) and traditional channel (TC) farmers were randomly selected from complete lists in 31 administrative locations within the County. A total of 402 farmers were selected in 2008. These farmers were surveyed in 2008, 2012, and 2015. A few farmer replacements were necessary over time due to sample attrition. By 2015, we had 409 farmers in the sample. Sample descriptive statistics are provided below. The sample is representative of vegetable farmers in the main vegetable-producing areas of Kiambu. 
Data were collected through face-to-face interviews using a structured questionnaire. We captured details of vegetable production and marketing, as well as other farm and off-farm economic activities of the households. The interviews were conducted in the local language with the household head or another household member who was responsible for vegetable production and marketing. The 2015 survey also included a choice experiment, details of which are provided below.

Figure 2.1 shows that the number of farmers supplying supermarkets and traditional channels changed remarkably between 2008 and 2015. The number of contracted supermarket suppliers more than halved between 2008 and 2012, and then again increased somewhat by 2015. However, those who dropped out of the supermarket channel by 2012 are mostly not the same as those who joined the supermarket channel after 2012. Out of the 409 farmers in $2015,281(69 \%)$ had never supplied supermarkets. In the following analysis, we refer to these 281 farmers as TC stayers. Only 34 farmers in the sample (8\%) had supplied supermarkets during the entire period 2008-2015 (SM stayers), 56 farmers (14\%) had a supermarket contract in 2008 but dropped out in subsequent years (SM dropouts), while 38 farmers (9\%) had not supplied supermarkets in 2008, but decided to enter the supermarket channel through a contract in subsequent years (SM newcomers).

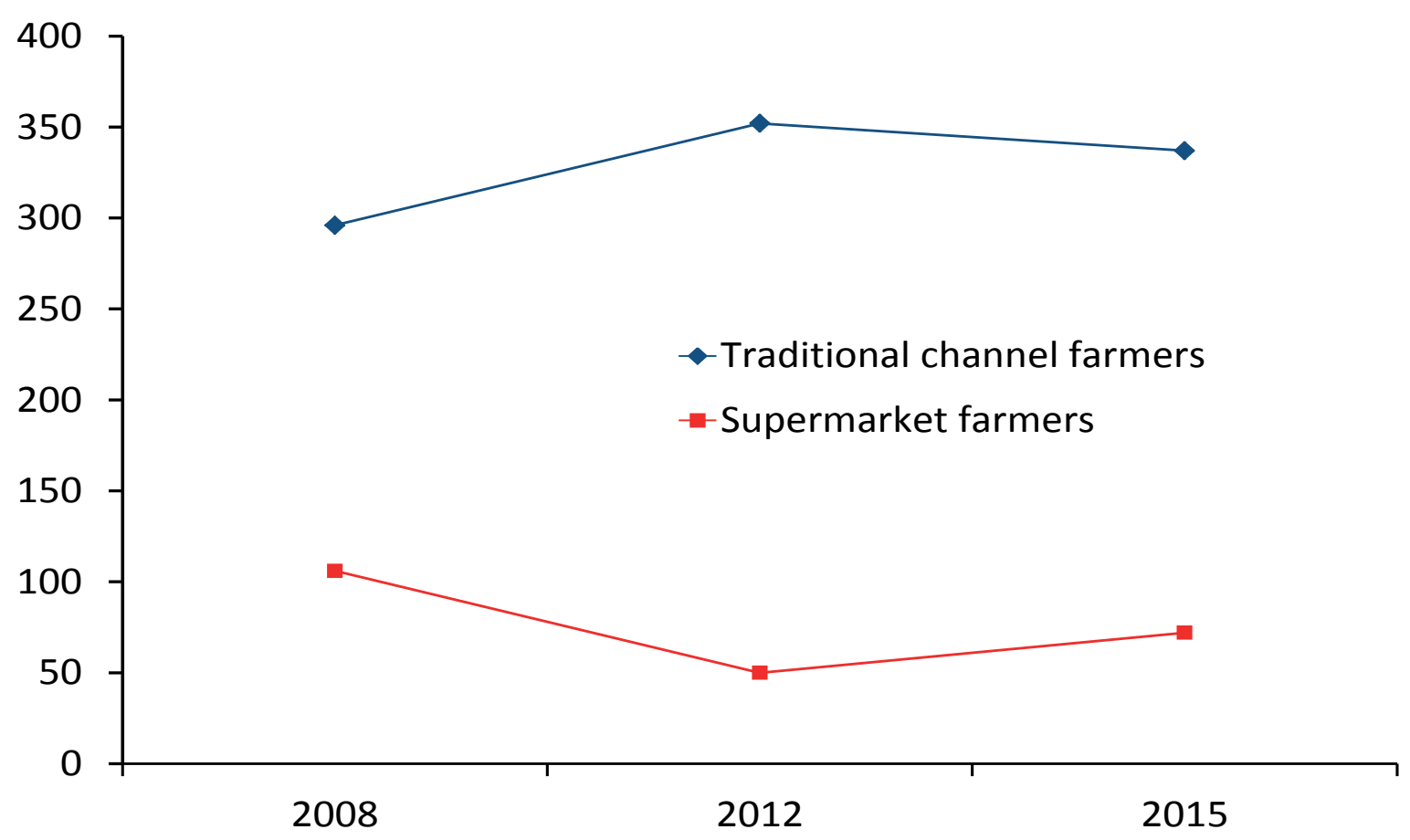

Figure 2. 1. Number of farmers supplying supermarkets and traditional channels (20082015) 


\subsubsection{Choice Experimental Approach}

Choice experiments have become a standard tool to evaluate the preferences of respondents with respect to hypothetical goods or services and are widely used in consumer research and environmental economics (Hensher et al., 2005; Louviere et al., 2010; Veettil et al., 2011). Recently, choice experiments have also gained popularity in an agricultural market context. A few recent studies have used choice experiments to assess marketing preferences of smallholder farmers in developing countries (Blandon et al., 2009b; Schipmann and Qaim, 2011; Bellemare, 2012; Gelaw et al., 2016; Vassalos et al., 2016).

Choice experiments are grounded on the microeconomic theory of consumer behavior and random utility theory (Lancaster, 1966; McFadden and Zarembka, 1974). It is assumed that consumers derive utility from the characteristics (attributes) of a good rather than the good itself. Individuals are assumed to choose alternatives that yield the highest utility among the range of available options. The actual choices observed thus provide useful insights into the underlying utility functions. In the context of this study, the "goods" are supermarket contracts with varying contract design attributes. In the experiment, a farmer can choose between $i$ different contract options. Farmer's utility for a particular contract option is composed of observable and unobservable parts:

$V_{i}^{j}=V\left(\boldsymbol{A}_{i}, \boldsymbol{F}_{i}^{j}\right)+\varepsilon_{i}^{j}$

where the observable component, $V\left(\boldsymbol{A}_{\boldsymbol{i}}, \boldsymbol{F}_{\boldsymbol{i}}^{\boldsymbol{j}}\right)$ is a function of $\boldsymbol{A}_{\boldsymbol{i}}$, a vector of design attributes of the contract, and $\boldsymbol{F}_{\boldsymbol{i}}^{j}$, a vector of socioeconomic characteristics that influence the farmer's choice. $\varepsilon_{i}^{j}$ is an independently and identically distributed error term that captures unobservable factors that may also influence farmer's choice. A farmer chooses alternative $i$, if $V_{i}>V_{k}$, that is, utility derived from $i$ is higher than utility derived from alternative $k$. The choice probabilities are derived with the assumption that the error term follows a logistic distribution (McFadden and Zarembka, 1974). 


\subsubsection{Contract Design Attributes}

The first step in designing a choice experiment is selecting relevant attributes and their corresponding levels (Hensher et al., 2005). The experiment was designed such that the attributes closely resembled those in the actual contracts that supermarkets issue to vegetable farmers in Kiambu (see previous section). The surveys in 2008 and 2012 and the related analyses (Rao and Qaim, 2011; Rao et al., 2012; Rao and Qaim, 2013; Andersson et al., 2015) were useful in designing the choice experiment that was conducted in 2015. In addition, several focus group discussions were carried out in Kiambu in late 2014 to understand farmers' views on different contract attributes in a qualitative way. Based on this information, we selected five attributes used in the choice experiment, as shown in Table 2.1.

The first contract attribute is price, expressed in Kenyan shillings (Ksh) per vegetable bundle. We used six price levels ranging from Ksh 10, the average price in traditional channels, to Ksh 20, the highest price supermarket farmers reported to have received in their contracts during recent years. The second attribute is the place of sale with three attribute levels (Table 2.1). As discussed, contracted farmers have to deliver their vegetables to supermarket stores in Nairobi (buyer's premise). This involves significant transportation and transaction costs (Andersson et al., 2015). The other two levels (farm gate and nearby market) were included to test how constraining these costs really are to farmers.

The third attribute is the form of sale with two attribute levels. "Sold as harvested" without any post-harvest treatment is the common form in traditional channels. However, supermarket farmers have to wash, sort, and bundle the vegetables ready for supermarket shelves. These post-harvest operations can be quite labor-intensive; most of the post-harvest handling is carried out by female household members or female hired workers (Rao and Qaim, 2013).

The fourth contract attribute relates to the timing of sales with three attribute levels. Traditional channel farmers can sell in the spot market whenever they want, while supermarket farmers have to deliver their vegetables according to the time schedule specified in the contract. The latter requires more careful planning and management of the production process. As explained, supermarkets have recently (especially after 2012) also started to procure vegetables by calling contracted farmers via phone whenever quantities are needed. This makes planning and crop management even more complex for farmers. 
Table 2. 1 Contract attributes and attribute levels

\begin{tabular}{|c|c|c|}
\hline Attribute & Levels & Description of attribute levels \\
\hline \multirow{6}{*}{ Price } & \multirow{6}{*}{ Price } & $10 \mathrm{Ksh}_{\text {per bundle }}^{\mathrm{a}}$ \\
\hline & & 12 Ksh per bundle \\
\hline & & 14 Ksh per bundle \\
\hline & & 16 Ksh per bundle \\
\hline & & 18 Ksh per bundle \\
\hline & & 20 Ksh per bundle \\
\hline \multirow{3}{*}{ Place of sale } & Place1 & Farm gate $^{\mathrm{a}}$ \\
\hline & Place2 & Nearby market \\
\hline & Place3 & Buyer's premise \\
\hline \multirow{2}{*}{ Form of sale } & Form1 & Sold as harvested $^{\mathrm{a}}$ \\
\hline & Form2 & Sold in washed and sorted form \\
\hline \multirow{3}{*}{ Timing of sale } & Timing1 & Sales possible at any time ${ }^{a}$ \\
\hline & Timing2 & Sales at times specified in the contract \\
\hline & Timing3 & Sales based on phone orders by buyer \\
\hline \multirow{5}{*}{ Payment mode } & Payment1 & Payment immediate, based on quantity delivered $^{\mathrm{a}}$ \\
\hline & Payment2 & Payment delayed, based on quantity delivered \\
\hline & Payment3 & $\begin{array}{l}\text { Payment delayed, based on quantity buyer sold to customers, } \\
\text { physically verifiable by farmer }\end{array}$ \\
\hline & Payment4 & $\begin{array}{l}\text { Payment delayed, based on quantity buyer sold to customers, } \\
\text { verifiable by farmer through bar coding system }\end{array}$ \\
\hline & Payment5 & $\begin{array}{l}\text { Payment delayed, based on quantity buyer sold to customers, not } \\
\text { verifiable by farmer }\end{array}$ \\
\hline
\end{tabular}

${ }^{\mathrm{a}}$ This attribute level is common in traditional marketing channels.

The fifth attribute relates to the payment mode. Whereas traditional channel farmers receive spot payments, in supermarket contracts payment delays are common. We further consider actual payments to the farmer, either for the quantity delivered, as was common in contracts until 2012, or for the quantity that the supermarket was able to sell to consumers, as has become common recently (see previous section). Finally, for the same attribute we differentiate between three options for the farmer to verify the quantity that the supermarket claims it was unable to sell. Modalities of verification are important especially when levels of trust between transacting partners are limited. The first option in our experiment is physical verification, meaning that the farmer can see and pick up the unsold quantity at the supermarket store. This was the existing arrangement at the time of the survey in 2015. The 
second option is through a barcoding system, where the farmer would get a computergenerated slip with sold and unsold quantities recorded by a barcode scanner. This second option is hypothetical, as such technology is not yet used by Kenyan supermarkets for vegetable sales. The third option is "not verifiable by the farmer" (Table 2.1).

These attributes and corresponding levels lead to 540 possible combinations $(6 \times 3 \times 2 \times 3 \times$ 5 ). We used the software $R$ to develop a D-optimal choice design. Fractional factorial design yielded a subset of the full factorial design choice alternatives while retaining the main and first-order interaction effects (Hensher et al., 2005). The choice design thus developed comprised 30 choice sets, blocked into five. Every respondent in the choice experiment was randomly assigned to one of the five blocks, each having six choice cards. Each choice card had three options, two contract options with varying attribute levels, and a no-contract option, representing the conditions in traditional channels. Respondents were asked to only choose one option in each of the six choice cards.

Prior to starting the choice experiment, detailed explanations on the differences between attributes and attribute levels were provided to farmers (see explanations and instructions used in the general appendix). On the choice cards, pictures were used to further facilitate farmers' understanding of the different options to choose from. An example of a choice card with English labels is shown in Figure 2.2.
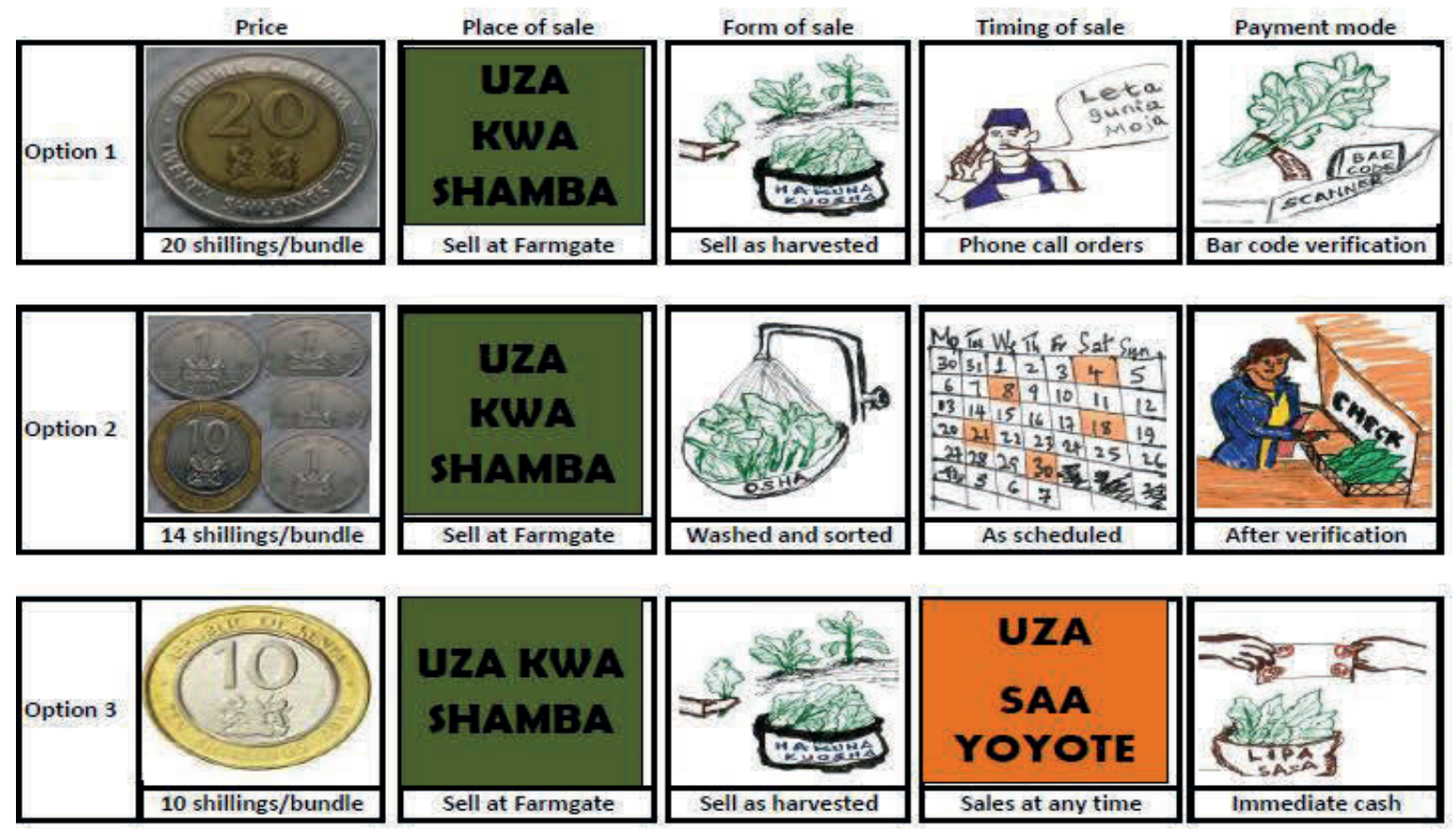

Figure 2. 2. Example of a choice card 


\subsubsection{Estimation Procedure}

In many empirical studies with choice experimental data, multinomial or conditional logit models have been used for data analysis. However, in more recent studies mixed logit models have become more popular (Hole, 2007). Unlike multinomial or conditional logit models, mixed logit models do not impose the restrictive independence of irrelevant alternatives (IIA) assumption. The unobserved factors (captured in the error term) are therefore allowed to be correlated over choice alternatives. Furthermore, mixed logit models take into account preference heterogeneity across respondents so that it is possible to elicit multiple choice sets from the same respondents with unrestricted substitution patterns (Hensher et al., 2005).

We start with a model that only includes the contract attributes as explanatory variables:

$Y_{n j t}=\alpha_{n} A S C+\beta P_{n j t}+\gamma_{n}^{\prime} \boldsymbol{A}_{n j t}+\varepsilon_{n j t}$

where $Y$ equals one if farmer $n$ chooses choice alternative $j$ given choice options $t . P$ is the price attribute, and $\boldsymbol{A}_{\boldsymbol{n} \boldsymbol{t}}$ the vector of other contract attributes, including place of sale, form of sale, timing of sale, and payment mode. Positive values for the estimated $\gamma$ coefficients imply that respondents have a positive preference for the particular attribute level, and vice versa. $\varepsilon$ is the random error term. ASC is the alternative-specific constant, which captures farmers' general preferences for contracts, beyond the contract attributes specified. The base scenario is dummy-coded; it takes a value of one if the no-contract option was chosen, meaning that a positive $\alpha$ coefficient implies negative general attitudes towards contracts, and vice versa.

In further specifications, we extend this model with additional explanatory variables. In particular, we include different sets of interaction terms to learn more about preference heterogeneity among farmers. Some farmers in our sample had real supermarket contracts in 2015 , others had contracts in the past, and yet others had no own experience with supermarket contracts. $^{2}$ To examine the role of farmers' own contract history, we estimate the following model:

$Y_{n j t}=\alpha_{n} A S C+\beta P_{n j t}+\gamma_{n}^{\prime} \boldsymbol{A}_{\boldsymbol{n} \boldsymbol{t}}+\delta^{\prime}{ }_{n}\left(A S C \times \boldsymbol{H}_{\boldsymbol{n}}\right)+\varepsilon_{n j t}$

where $\boldsymbol{H}$ is a vector of dummy variables characterizing SM stayers, SM dropouts, and SM newcomers. TC stayers are used as the reference group. Positive $\delta$ coefficients mean that

\footnotetext{
${ }^{2}$ We also test whether pooling of observations from supermarket and traditional channel farmers in one model is permissible. This is further elaborated in the results section.
} 
farmers in the particular group have stronger negative attitudes towards contracts than farmers in the group of TC stayers, and vice versa.

We also analyze the possible role of other socioeconomic characteristics:

$$
Y_{n j t}=\alpha_{n} A S C+\beta P_{n j t}+\gamma_{n}^{\prime} \boldsymbol{A}_{n j t}+\rho_{n}^{\prime}\left(A S C \times \boldsymbol{S}_{\boldsymbol{n}}\right)+\varepsilon_{n j t}
$$

where $\boldsymbol{S}$ is a vector of socioeconomic variables, including farm characteristics, farmer's age, education, and gender, as well as household income and region dummies.

Socioeconomic factors may not only influence farmers' general contract preferences but also their attitude towards particular contract attributes. This is analyzed with the following model:

$Y_{n j t}=\alpha_{n} A S C+\beta P_{n j t}+\gamma_{n}^{\prime} \boldsymbol{A}_{n j t}+\tau_{n}^{\prime}\left(\boldsymbol{A}_{n j t} \times \boldsymbol{S}_{\boldsymbol{n}}\right)+\varepsilon_{n j t}$

Positive $\tau$ coefficients mean that farmers with higher levels of $\boldsymbol{S}$ have more positive (or less negative) attitudes towards a particular contract attribute level, and vice versa.

Using dummy coding, all models are estimated in preference space, which leads to a better fit in mixed logit models than when estimating in willingness to pay space (Hole and Kolstad, 2012). For the price attribute, we assume a fixed coefficient, while for all other contract attributes we assume preference heterogeneity across respondents with normal distribution. This is a common approach in the choice experimental literature (Hensher et al., 2005). Following Hole (2007), simulated maximum likelihood method was used to estimate the parameters. The estimates were run in Stata version 13.

By rearranging equation (2), we determine price $(P)$ as follows:

$P_{n j t}=\left[Y_{n j t}-\alpha_{n} A S C-\gamma_{n}^{\prime} \boldsymbol{A}_{n j t}-\varepsilon_{n j t}\right] / \beta$

Willingness to accept (WTA) estimates for each attribute level are obtained from partial derivatives of $P$ with respect to $A$ as follows:

$W T A=\partial P / \partial A=-\gamma_{n}^{\prime} / \beta$.

Positive WTA estimates imply that farmers would only accept a particular contract attribute level when being offered a higher price. Like the price attribute, WTA is expressed in Ksh. Comparing WTA estimates between the different attributes and attribute levels can help 
identify contract terms that are seen by farmers as particularly critical. All the mixed logit models estimated are uncorrelated, meaning that we assumed independent and normally distributed coefficient estimates. Likelihood ratio tests for independent groups show that uncorrelated models are preferred over correlated ones.

\subsection{Results and Discussion}

\subsubsection{Descriptive Statistics}

Table 2.2 presents summary statistics of selected socioeconomic variables for the sample of farm households in Kiambu. Most farms are very small, averaging 1.8 acres, with a vegetable area of about 0.5 acres. Farmers in the sample grow leafy vegetables primarily for sale. In addition, they typically grow maize, bananas, and a few other cash crops. Many are also involved in off-farm economic activities. Vegetable production is the main source of income for most sample households. The majority of the farmers $(86 \%)$ are members of a farmer group, although many of the groups are not very active. ${ }^{3}$ Only $8 \%$ of the farmers market their vegetables in a coordinated way through the groups.

Sample mean values of many of the key variables - such as farm size and vegetable area - are similar to those reported in other studies on farmers in Central Kenya producing vegetables for the domestic market (Neven et al., 2009). Production for the export market is hardly observed in Kiambu County. Vegetable farms involved in export markets in other Kenyan counties are somewhat larger, with mean farm sizes of 3-4 acres (Asfaw et al., 2010; Muriithi and Matz, 2015).

A breakdown of our sample from Kiambu by supermarket (SM) and traditional channel (TC) farmers is shown in Table A2.1 of appendix to chapter 2. We find significant differences between the two groups for many of the variables. SM farmers have better educational levels, better access to credit, and higher incomes than TC farmers. In Table A2.2 of appendix to chapter 2, we compare key variables for the two groups of farmers over the three survey rounds. In Table A2.3 of appendix to chapter 2, we show descriptive statistics for 2015, differentiating by farmers with different contracting history.

\footnotetext{
${ }^{3}$ Farmer groups in Kenya are often established with a particular project in mind. Some groups remain active also after the project ended. Other groups continue to exist on paper, yet without much activity. Sometimes, passive groups can be revived when a new project is initiated.
} 
Table 2. 2 Summary statistics of selected socioeconomic variables (2015)

\begin{tabular}{llcc}
\hline Variable & Description of variable & Mean & SE \\
\hline Farm size & Land owned by household (acres) & 1.81 & 0.14 \\
Farm income & Annual farm income (000 Ksh) & 418.63 & 46.42 \\
Off-farm income & Households has off-farm income sources (dummy) & 0.78 & 0.02 \\
Total income & Annual household income (000 Ksh) & 556.57 & 50.36 \\
Irrigation & Access to advanced irrigation technology (dummy) & 0.72 & 0.02 \\
Vegetable area & Land cultivated with vegetables in 2015 (acres) & 0.54 & 0.04 \\
Vegetable share & Contribution of vegetable income to total farm income (\%) & 0.84 & 0.01 \\
Group member & Membership in farmer group (dummy) & 0.86 & 0.02 \\
Group marketing & Vegetables are marketed through farmer group (dummy) & 0.08 & 0.01 \\
Distance & Distance to the nearest supermarket (km) & 9.79 & 0.43 \\
Credit access & Household has access to credit (dummy) & 0.72 & 0.02 \\
Livestock & Ownership of livestock (dummy) & 0.84 & 0.02 \\
Male & Male household head (dummy) & 0.86 & 0.02 \\
Age & Age of household head (years) & 54.31 & 0.70 \\
Education & Years of schooling of household head (years) & 9.67 & 0.18 \\
\hline
\end{tabular}

Notes: Observations $=409$; SE, standard error; 1 US dollar $=103$ Kenya shillings (Ksh).

\subsubsection{Farmers' Preferences for Contracts and Contract Attributes}

We start by testing the appropriateness of model specifications. Estimation results of the first set of mixed logit models are shown in Table 2.3. In the first column, the total sample of SM and TC farmers is pooled. We tested for the IIA assumption using a Hausman test. The null hypothesis that the IIA assumption holds had to be rejected $(p<0.05)$, implying that the mixed logit model is preferred over multinomial or conditional logit models. The superiority of the mixed logit is also underlined by the significant standard deviation estimates, which are shown in the lower part of Table 2.3. The significance of these estimates confirms that heterogeneity in farmers' preferences for the different contract attributes exists.

Given the observed differences between SM and TC farmers in Table A2.1 of appendix to chapter 2, we also tested whether pooling of the two groups in one model is actually appropriate. For this, we estimated separate models for the two subsamples, which are shown in the second and third columns of Table 2.3. Differences in coefficient estimates between the two separate models are tested in the last Table column. Most of the differences are indeed statistically significant, so that relying on the pooled model alone could possibly lead to misinterpretation. In the subsequent analysis, we use the separate models to highlight differences in preferences between SM and TC farmers. Only for some more general statements on preference directions we use the pooled model results, which are more efficient 
due to the larger number of observations included. This is permissible because the coefficient signs are the same across all three models shown in Table 2.3.

Table 2. 3 Mixed logit model estimates of farmers' general preferences for contracts

\begin{tabular}{|c|c|c|c|c|}
\hline & Pooled sample & SM farmers & TC farmers & $\mathrm{H}_{0}: \boldsymbol{\beta}_{\mathrm{SM}}=\boldsymbol{\beta}_{\mathrm{TC}}$ \\
\hline \multicolumn{5}{|l|}{ Parameters } \\
\hline ASC & $0.95^{* * *}(0.27)$ & $0.85^{*}(0.50)$ & $0.76^{* *}(0.36)$ & $\mathrm{p}>0.05$ \\
\hline Price & $0.34^{* * *}(0.03)$ & $0.29^{* * *}(0.10)$ & $0.34^{* * *}(0.04)$ & $\mathrm{p}<0.01$ \\
\hline Sales at a nearby market (place2) & $-1.21^{* * *}(0.26)$ & $-0.50(0.50)$ & $-1.12^{* * *}(0.29)$ & $\mathrm{p}<0.01$ \\
\hline Sales at buyers' premises (place 3 ) & $-0.86^{* * *}(0.24)$ & $-0.10(0.75)$ & $-1.11^{* * *}(0.32)$ & $\mathrm{p}<0.01$ \\
\hline Sold in washed and sorted form (form2) & $-0.33^{* *}(0.16)$ & $-0.50(0.42)$ & $-0.36(0.23)$ & $\mathrm{p}<0.01$ \\
\hline Sales as scheduled in contract (timing2) & $-0.25(0.21)$ & $0.17(0.49)$ & $-0.33(0.24)$ & $\mathrm{p}<0.01$ \\
\hline Sales based on phone orders (timing 3 ) & $-0.88^{* * *}(0.29)$ & $-0.43(0.43)$ & $-1.11^{* *}(0.44)$ & $\mathrm{p}<0.01$ \\
\hline $\begin{array}{l}\text { Payment delayed, for quantity delivered } \\
\text { (payment2) }\end{array}$ & $-1.86^{* * *}(0.29)$ & $-0.31(0.53)$ & $-2.30^{* * *}(0.35)$ & $\mathrm{p}<0.01$ \\
\hline $\begin{array}{l}\text { Payment delayed, for quantity sold to } \\
\text { customers, physically verifiable (payment } 3 \text { ) }\end{array}$ & $-4.58^{* * *}(0.49)$ & $-3.66^{*}(2.00)$ & $-5.01^{* * *}(0.92)$ & $\mathrm{p}<0.01$ \\
\hline $\begin{array}{l}\text { Payment delayed, for quantity sold to } \\
\text { customers, verifiable through bar coding } \\
\text { (payment } 4 \text { ) }\end{array}$ & $-5.85^{* * *}(0.63)$ & $-4.56(3.13)$ & $-6.41^{* * *}(1.31)$ & $\mathrm{p}<0.01$ \\
\hline $\begin{array}{l}\text { Payment delayed, for quantity sold to } \\
\text { customers, not verifiable (payment5) }\end{array}$ & $-7.79^{* * *}(1.07)$ & $-6.91(6.05)$ & $-8.03^{* * *}(1.54)$ & $\mathrm{p}<0.01$ \\
\hline \multicolumn{5}{|l|}{ Standard deviations } \\
\hline ASC & $2.22^{* * *}(0.20)$ & $1.54^{* * *}(0.51)$ & $2.27^{* * *}(0.30)$ & $\mathrm{p}<0.01$ \\
\hline Place2 & $1.22^{* * *}(0.25)$ & $0.74(1.20)$ & $-0.03(1.10)$ & $\mathrm{p}<0.01$ \\
\hline Place3 & $3.44^{* * *}(0.28)$ & $1.41(1.43)$ & $1.29^{* * *}(0.46)$ & $\mathrm{p}>0.05$ \\
\hline Form2 & $-0.02(0.28)$ & $0.10(0.42)$ & $-0.54(0.36)$ & $\mathrm{p}<0.01$ \\
\hline Timing2 & $-0.98^{* *}(0.44)$ & $-1.63(1.40)$ & $-0.77(0.70)$ & $\mathrm{p}<0.01$ \\
\hline Timing3 & $1.89^{* * *}(0.34)$ & $0.49(0.74)$ & $2.47^{* * *}(0.55)$ & $\mathrm{p}<0.01$ \\
\hline Payment2 & $2.14^{* * *}(0.29)$ & $-0.72(0.68)$ & $2.38^{* * *}(0.40)$ & $\mathrm{p}<0.01$ \\
\hline Payment3 & $1.43^{* * *}(0.46)$ & $2.50(1.55)$ & $1.38(1.07)$ & $\mathrm{p}<0.01$ \\
\hline Payment4 & $2.41^{* * *}(0.51)$ & $3.09(2.58)$ & $2.47^{*}(1.33)$ & $\mathrm{p}<0.05$ \\
\hline Payment5 & $3.38^{* * *}(0.77)$ & $-5.10(5.71)$ & $3.18^{* * *}(0.92)$ & $\mathrm{p}<0.01$ \\
\hline$N$ (Number of farmers) & 409 & 72 & 337 & \\
\hline$N$ (Number of observations) & 7362 & 1296 & 6066 & \\
\hline Log likelihood at start & -1600.58 & -351.71 & -1207.04 & \\
\hline Log likelihood at convergence & -1393.21 & -321.04 & -1043.81 & \\
\hline Wald chi $^{2}$ & $181.56^{* * *}$ & $42.43^{* * *}$ & $134.60^{* * *}$ & \\
\hline Pseudo $R^{2}$ & 0.26 & 0.21 & 0.31 & \\
\hline
\end{tabular}

Notes: Coefficient estimates are shown with standard errors in parentheses (clustered by individual). The binary dependent variable is marketing channel (contract) choice. For place of sale, the reference is "farm gate" (place1). For form of sale, the reference is "sold as harvested" (form1). For time of sale, the reference is "at any time" (timing1). For payment mode, the reference is "payment immediate, based on quantity delivered" (payment1). ASC, alternative specific constant (refers to traditional channel without contract); SM, supermarket; TC, traditional channel. ${ }^{*},{ }^{* *},{ }^{* * *}$ Significant at the $10 \%, 5 \%$, and $1 \%$ level, respectively.

Taking a closer look at the estimates in Table 2.3, the ASC coefficient is positive and significant in all three models, implying that farmers prefer selling in the traditional spot market over selling under contract, if all other conditions are held equal. Concerning the contract attributes, the positive estimate for price indicates that, ceteris paribus, farmers prefer contracts when they offer higher prices, which is to be expected. For all other contract 
attributes, we observe negative coefficients (most of which are significant in the pooled model), meaning that farmers do not like these contractual terms and conditions and are only willing to accept them when being compensated through higher prices. This is also expected.

Having to deliver to a nearby market (place2) or to the supermarket in Nairobi (place3) is associated with higher transport and transaction costs than selling at the farm gate. Washing and sorting the vegetables (form2) requires more work than selling as harvested. Selling on short notice when called by supermarket procurement officers (timing3) makes planning and crop management more complex. Delayed payments (payment2) and unpredictable rates of product rejection increase farmers' economic risks. The magnitude of the coefficients and related WTA estimates will be discussed in more detail below. However, a quick comparison of the estimated coefficients already suggests that the payment mode attribute is seen as particularly critical by farmers, and especially by TC suppliers.

In Table 2.4 (columns 1-3), we test for the influence of farmers' contracting history in shaping their preferences (equation 3). Results for the pooled model (column 1) suggest that SM stayers have a more positive attitude towards contracts than the other groups of farmers. This is plausible, given that SM stayers started to produce under contract early on and also remained in that channel. Among the SM farmers (column 2), newcomers to this channel have a more positive attitude towards contracts than SM stayers. This also makes sense, given that SM newcomers recently decided to enter into a contractual relationship.

\subsubsection{The Role of Socioeconomic Characteristics}

In columns (4) to (6) of Table 2.4, we test for the influence of various socioeconomic characteristics (equation 4). In all three models, the interaction of ASC and Westlands is negative and statistically significant, meaning that farmers in Westlands have a more positive general attitude towards contracts than farmers from the Lari/Limuru region, which is the reference. In contrast, the interaction of ASC and Githunguri is positive and significant in two of the models, implying that farmers from Githunguri have a less positive general attitude towards contracts. ${ }^{4}$ Out of the regions surveyed, Githunguri is the one furthest away from Nairobi and has relatively poor road infrastructure. Farmers in that region therefore have a locational disadvantage for contracts with supermarkets in Nairobi. As is known from the

\footnotetext{
${ }^{4}$ There are too few SM farmer observations in Githunguri, so that this variable dropped out of the SM model in column (5) of Table 2.4 .
} 
literature, remoteness does not only reduce farmers' market access in general but can also obstruct their participation in higher-value supply chains (Moustier et al., 2010).

The interaction of ASC and group marketing is negative and significant for SM farmers (column 5), indicating that farmers who market their vegetables through a farmer group have a more positive preference for contracts than farmers who market individually. This is plausible, given that collective marketing can reduce transport and transaction costs (Andersson et al., 2015). Furthermore, active farmer groups are important platforms for learning and information exchange, which can be particularly relevant in meeting standards of product quality and consistency. The interaction of ASC and age of household head is negative and significant as well, meaning that older SM farmers have more positive general attitudes towards contracts than younger ones. This may possibly be related to higher levels of experience, which can help to better cope with new requirements in emerging supply chains. 
Table 2. 4 Estimates of the influence of contracting history and socioeconomic characteristics on farmers' preferences for contracts

\begin{tabular}{|c|c|c|c|c|c|c|}
\hline & $\begin{array}{c}\text { (1) } \\
\text { Pooled }\end{array}$ & $\begin{array}{c}(2) \\
\text { SM farmers }\end{array}$ & $\begin{array}{c}\text { (3) } \\
\text { TC farmers }\end{array}$ & $\begin{array}{c}(4) \\
\text { Pooled }\end{array}$ & $\begin{array}{l}(5) \\
\text { SM farmers }\end{array}$ & $\begin{array}{c}\text { (6) } \\
\text { TC farmers }\end{array}$ \\
\hline \multicolumn{7}{|l|}{ Parameters } \\
\hline ASC & $1.24^{* * *}(0.30)$ & $0.40(0.56)$ & $0.84^{* * *}(0.31)$ & $1.86^{* *}(0.93)$ & $7.46^{* * *}(2.02)$ & $0.85(1.23)$ \\
\hline Price & $0.32^{* * *}(0.03)$ & $0.24^{* * *}(0.04)$ & $0.34^{* * *}(0.04)$ & $0.33^{* * *}(0.03)$ & $0.26^{* * *}(0.05)$ & $0.34^{* * *}(0.05)$ \\
\hline Sales at buyers' premises (place 3 ) & $-0.75^{* * *}(0.24)$ & $-0.11^{* * *}(0.39)$ & $-1.12^{* * *}(0.32)$ & $-0.82^{* * *}(0.24)$ & $0.09(0.36)$ & $-1.24^{* * *}(0.40)$ \\
\hline Sold in washed and sorted form (form2) & $-0.27^{*}(0.16)$ & $-0.34(0.24)$ & $-0.36^{*}(0.20)$ & $-0.30^{*}(0.16)$ & $-0.41^{*}(0.24)$ & $-0.40(0.28)$ \\
\hline Payment delayed, for quantity delivered (payment2) & $-1.74^{* * *}(0.28)$ & $-0.01(0.36)$ & $-2.22^{* * *}(0.31)$ & $-1.79^{* * *}(0.28)$ & $-0.08(0.36)$ & $-2.36^{* * *}(0.40)$ \\
\hline $\begin{array}{l}\text { Payment delayed, for quantity sold to customers, } \\
\text { physically verifiable (payment3) }\end{array}$ & $-4.23^{* * *}(0.47)$ & $-2.70^{* * *}(0.69)$ & $-5.03^{* * *}(0.91)$ & $-4.48^{* * *}(0.54)$ & $-3.06^{* * *}(1.20)$ & $-5.16^{* * *}(1.22)$ \\
\hline $\begin{array}{l}\text { Payment delayed, for quantity sold to customers, } \\
\text { verifiable through bar coding (payment } 4 \text { ) }\end{array}$ & $-5.49^{* * *}(0.63)$ & $-2.68^{* * *}(1.00)$ & $-6.81^{* * *}(1.22)$ & $-5.73^{* * *}(0.62)$ & $-3.47^{* * *}(0.97)$ & $-6.86^{* *}(2.75)$ \\
\hline $\begin{array}{l}\text { Payment delayed, for quantity sold to customers, not } \\
\text { verifiable (payment5) } \\
\text { Interactions }\end{array}$ & $-7.23^{* * *}(1.17)$ & $-3.71^{* * *}(1.23)$ & $-7.85^{* * *}(1.48)$ & $-7.58^{* * *}(1.13)$ & $-3.92^{* * *}(0.94)$ & $-8.29^{* * *}(1.54)$ \\
\hline ASC x Githunguri region (dummy) & & & & $1.35^{* *}(0.53)$ & & $1.12^{*}(0.61)$ \\
\hline ASC x Westlands region (dummy) & & & & $-1.62^{* *}(0.77)$ & $-2.17^{* *}(0.98)$ & $-1.89^{*}(1.00)$ \\
\hline ASC x Kikuyu region (dummy) & & & & $0.10(0.29)$ & $-1.38^{*}(0.76)$ & $0.21(0.38)$ \\
\hline ASC x Group marketing (dummy) & & & & $-1.31^{* *}(0.53)$ & $-1.84^{* *}(0.75)$ & $-0.84(0.77)$ \\
\hline ASC x Age (years) & & & & $-0.002(0.02)$ & $-0.05^{* *}(0.02)$ & $0.01(0.02)$ \\
\hline ASC x Education (years) & & & & $-0.02(0.04)$ & $-0.11(0.10)$ & $0.001(0.00)$ \\
\hline ASC x Male (dummy) & & & & $-0.57(0.39)$ & $-0.99(0.77)$ & $-0.51(0.47)$ \\
\hline ASC x Annual income (000 Ksh) & & & & $-0.00020^{*}(0.00011)$ & $-2.07 e-4(0.00)$ & $-0.001(0.00)$ \\
\hline
\end{tabular}


Table 2.4. (continued)

\begin{tabular}{|c|c|c|c|c|c|c|}
\hline \multicolumn{7}{|l|}{ Standard deviations } \\
\hline ASC & $2.05^{* * *}(0.21)$ & $1.49^{* * *}(0.36)$ & $0.84^{* * *}(0.31)$ & $2.07^{* * *}(0.21)$ & $1.35^{* * *}(0.30)$ & $2.22^{* * *}(0.37)$ \\
\hline Place2 & $1.05^{* * *}(0.30)$ & $0.77(0.62)$ & $-1.22^{* * *}(0.40)$ & $1.09^{* * *}(0.26)$ & $-0.77(0.48)$ & $0.05(0.99)$ \\
\hline Place3 & $1.21^{* * *}(0.33)$ & $0.50(1.24)$ & $-1.29^{* *}(0.57)$ & $1.33^{* * *}(0.28)$ & $0.79(0.69)$ & $1.53^{* * *}(0.46)$ \\
\hline Form2 & $-0.15(0.34)$ & $0.04(0.40)$ & $-0.32(0.29)$ & $-0.12(0.27)$ & $-0.40(0.40)$ & $-0.51(0.45)$ \\
\hline Timing2 & $-0.93^{* *}(0.68)$ & $0.88^{*}(0.49)$ & $0.62^{*}(0.36)$ & $-1.06^{* * *}(0.52)$ & $-0.85(0.57)$ & $-0.73(0.62)$ \\
\hline Timing3 & $1.73^{* * *}(0.50)$ & $-0.31(0.69)$ & $2.28^{* * *}(1.42)$ & $1.92^{* * *}(0.35)$ & $0.32(0.53)$ & $2.61^{* * *}(0.54)$ \\
\hline Payment2 & $2.00^{* * *}(0.32)$ & $0.13(0.67)$ & $2.42^{* * *}(0.39)$ & $1.97^{* * *}(0.32)$ & $0.35(0.41)$ & $2.36^{* * *}(0.43)$ \\
\hline Payment3 & $1.10^{*}(0.58)$ & $1.66^{* *}(0.80)$ & $1.42(1.06)$ & $1.31^{* *}(0.56)$ & $2.07^{* *}(0.97)$ & $1.47(1.51)$ \\
\hline Payment4 & $2.15^{* * *}(0.50)$ & $1.21(1.68)$ & $2.86^{* *}(1.11)$ & $2.31^{* * *}(0.46)$ & $-2.44^{* * *}(0.86)$ & $2.89(2.60)$ \\
\hline Payment5 & $3.01^{* * *}(0.86)$ & $1.88(1.26)$ & $3.05^{* * *}(0.86)$ & $3.21^{* * *}(0.80)$ & $1.88^{* *}(0.76)$ & $3.30^{* * *}(1.00)$ \\
\hline Number of observations & 7362 & 1296 & 6066 & 7362 & 1296 & 6066 \\
\hline Log likelihood at start & -1568.68 & -343.99 & -1206.20 & -1563.49 & -338.78 & -1192.51 \\
\hline Log likelihood at convergence & -1386.34 & -320.32 & -1043.29 & -1380.19 & -313.33 & -1036.95 \\
\hline Wald chi $^{2}$ & $233.08^{* * *}$ & $106.16^{* * *}$ & $170.22^{* * *}$ & $202.39^{* * *}$ & $98.91^{* * *}$ & $116.47^{* * *}$ \\
\hline Pseudo $\mathrm{R}^{2}$ & 0.27 & 0.21 & 0.31 & 0.27 & 0.20 & 0.30 \\
\hline
\end{tabular}

Notes: Coefficient estimates are shown with standard errors in parentheses (clustered by individual). The binary dependent variable is marketing channel (contract) choice. For place of sale, the reference is "farm gate" (place1). For form of sale, the reference is "sold as harvested" (form1). For time of sale, the reference is "at any time" (timing1). For payment mode, the reference is "payment immediate, based on quantity delivered" (payment1). For the regional dummies, the reference is Lari/Limuru region. ASC, alternative specific constant (refers to traditional channel without contract); SM, supermarket; TC, traditional channel. ${ }^{*}$ significant at $10 \%$ level; ${ }^{*},{ }^{* *},{ }^{* * *}$ Significant at the $10 \%, 5 \%$, and $1 \%$ level, respectively. 
Besides influencing general contract preferences, socioeconomic characteristics can also influence attitudes towards the different contract attributes. This is tested by interacting contract attributes with socioeconomic variables (equation 5). The main results of these models are shown in Table 2.5 (full results are shown in Tables A2.5 and A2.6 of appendix to chapter 2. These estimates are based on separate models for SM farmers (upper part of Table 2.5) and TC farmers (lower part of Table 2.5). In column (1), the contract attributes were interacted with the age of the household head. Each interaction term has to be considered together with the coefficient of the corresponding contract attribute itself. For instance, for TC farmers the coefficient for the interaction of age and place2 is negative and significant, meaning that older TC farmers have more negative attitudes towards delivering their vegetables to a nearby marketplace than younger farmers. Probably, older farmers are less mobile.

At the same time, the coefficient for place 2 itself, which is negative and significant in the models in Table 2.3, is now insignificant. This implies that younger farmers have no problem with delivering their vegetables to a nearby marketplace (compared to selling at the farm gate). Nearby markets are usually located in the next town, to which younger farmers travel more frequently than older farmers anyway.

In column (2) of Table 2.5, the contract attributes are interacted with education. Better educated TC farmers have more positive attitudes towards having to deliver their vegetables to a nearby market than less educated TC farmers. The results also indicate that better educated TC farmers have fewer problems with adjusting to fixed time schedules for vegetable supplies (timing2). Column (3) looks at the role of household income. Richer farmers have a less negative attitude towards delayed payments (payment2), which is true for both TC and SM farmers. This is plausible given that richer farmers tend to be less affected by liquidity constraints than poorer ones. Most other interaction effects in this model are insignificant, meaning that income does not affect farmers' preferences for these other contract attributes.

In column (4) of Table 2.5, the only significant interaction terms are those between the Kikuyu region and some of the payment mode attributes. Farmers in Kikuyu have a more negative attitude towards payment based on quantities the supermarket states it was able to sell, especially when these statements cannot be physically verified. 
Table 2. 5 Mixed logit models with interactions between contract attributes and socioeconomic characteristics

\begin{tabular}{|c|c|c|c|c|c|}
\hline & \multicolumn{5}{|c|}{ Variables interacted with attribute levels } \\
\hline & (1) & (2) & (3) & (4) & (5) \\
\hline & Age (years) & Education (years) & Income (000 Ksh) & Kikuyu (dummy) & Group marketing (dummy) \\
\hline Interacted with... & & & SM farmers & & \\
\hline ...Payment2 & $-0.02(0.02)$ & $0.10(0.14)$ & $0.0003^{*}(0.0001)$ & $-0.53(0.58)$ & $0.04(0.74)$ \\
\hline ...Payment4 & $0.04(0.05)$ & $-0.40(0.35)$ & $0.0002(0.0003)$ & $-1.73^{*}(0.90)$ & $1.70(1.59)$ \\
\hline ...Payment5 & $0.01(0.05)$ & $0.11(0.36)$ & $0.0001(0.0004)$ & $-2.13^{*}(1.14)$ & $3.01(2.36)$ \\
\hline \multicolumn{6}{|l|}{ Parameters } \\
\hline ASC & $0.96^{*}(0.50)$ & $1.17^{* *}(0.57)$ & $1.01^{* *}(0.51)$ & $1.10^{* *}(0.52)$ & $0.94^{*}(0.51)$ \\
\hline Payment2 & $0.79(1.31)$ & $-1.30(1.70)$ & $-0.45(0.43)$ & $0.18(0.47)$ & $-0.13(0.46)$ \\
\hline Payment4 & $-4.92(3.86)$ & $-0.21(2.43)$ & $-3.31^{* * *}(0.79)$ & $-2.24^{* *}(0.90)$ & $-4.04^{*}(2.35)$ \\
\hline Payment5 & $-4.65(3.58)$ & $-3.94(6.87)$ & $-4.50(3.07)$ & $-2.82^{* * *}(1.01)$ & $-4.76(3.66)$ \\
\hline Interacted with... & & & TC farmers & & \\
\hline ...Place2 & $-0.04^{* *}(0.02)$ & $0.15^{* *}(0.06)$ & $2.99 \mathrm{e}-05(0.0004)$ & $0.54(0.44)$ & $-2.01(1.46)$ \\
\hline ...Timing2 & $-0.01(0.01)$ & $0.09^{* *}(0.05)$ & $-0.001^{* *}(0.0003)$ & $-0.27(0.38)$ & $1.48^{*}(0.87)$ \\
\hline ...Payment2 & $0.01(0.02)$ & $0.03(0.07)$ & $0.0007^{*}(0.0004)$ & $-0.52(0.52)$ & $0.71(1.29)$ \\
\hline ...Payment4 & $0.03(0.03)$ & $0.01(0.12)$ & $-0.002^{* *}(0.0009)$ & $-0.83(1.11)$ & $1.59(1.59)$ \\
\hline ...Payment5 & $0.03(0.04)$ & $0.17(0.17)$ & $-0.001(0.001)$ & $-4.89^{* * *}(0.99)$ & $-0.13(2.64)$ \\
\hline \multicolumn{6}{|l|}{ Parameters } \\
\hline ASC & $0.85^{* *}(0.35)$ & $0.75^{* *}(0.32)$ & $0.80^{* *}(0.32)$ & $0.82^{* * *}(0.31)$ & $0.79^{* *}(0.32)$ \\
\hline Place2 & $0.50(0.82)$ & $-2.64^{* * *}(0.74)$ & $-1.31^{* * *}(0.48)$ & $-1.49^{* * *}(0.38)$ & $-1.39^{* * *}(0.31)$ \\
\hline Timing2 & $0.20(0.80)$ & $-1.27^{* *}(0.51)$ & $-0.70^{* *}(0.28)$ & $-0.20(0.27)$ & $-0.39(0.26)$ \\
\hline Payment2 & $-2.74^{* *}(1.23)$ & $-2.65^{* * *}(0.82)$ & $-2.70^{* * *}(0.40)$ & $-2.07^{* * *}(0.38)$ & $-2.46^{* * *}(0.39)$ \\
\hline Payment4 & $-8.18^{* * *}(1.96)$ & $-6.77^{* * *}(1.34)$ & $-6.23^{* * *}(1.16)$ & $-6.76^{* * *}(0.95)$ & $-6.51^{* * *}(0.78)$ \\
\hline Payment5 & $-10.16^{* * *}(2.48)$ & $-9.77^{* * *}(2.64)$ & $-8.75^{* * *}(1.57)$ & $-6.47^{* * *}(0.89)$ & $-9.86^{* * *}(1.30)$ \\
\hline
\end{tabular}


Column (5) shows interactions between group marketing and contract attributes. TC farmers that market their vegetables through a group are more positive about fixed delivery schedules (timing2) than their colleagues who market individually. Group marketing requires timely coordination anyway, with and without supermarket contracts.

\subsubsection{Farmers' Willingness to Accept}

The model estimates so far have shown that farmers have varied attitudes towards contracting in general, dislike some of the typical attributes in supermarket contracts, and are only willing to contract when the disadvantages are compensated through higher product prices. Now we want to analyze farmers' willingness to accept (WTA) these contract attributes more explicitly. Mean WTA estimates for each contract attribute level are shown in Table 2.6, for the pooled sample as well as separately for SM and TC farmers.

Table 2. 6 Mean willingness to accept (WTA) different contract attribute levels

\begin{tabular}{|c|c|c|c|}
\hline Attribute level & Pooled sample & SM farmers & TC farmers \\
\hline \multirow[t]{2}{*}{ Sales at a nearby market (place2) } & 3.04 & $1.80^{* * *}$ & 3.31 \\
\hline & {$[2.98,3.11]$} & {$[1.59,2.01]$} & {$[3.31,3.31]$} \\
\hline \multirow[t]{2}{*}{ Sales at buyers' premise (place 3 ) } & 2.76 & $0.22^{* * *}$ & 3.30 \\
\hline & {$[2.55,2.97]$} & {$[-0.40,0.84]$} & {$[3.14,3.46]$} \\
\hline \multirow[t]{2}{*}{ Sold in washed and sorted form (form2) } & 1.16 & 1.74 & 1.05 \\
\hline & {$[1.13,1.21]$} & {$[1.72,1.75]$} & {$[1.01,1.09]$} \\
\hline \multirow[t]{2}{*}{ Sales as scheduled in contract (timing2) } & 0.68 & $-0.69^{* * *}$ & 0.97 \\
\hline & {$[0.52,0.83]$} & {$[-1.44,0.06]$} & {$[0.91,1.03]$} \\
\hline \multirow[t]{2}{*}{ Sales based on phone orders (timing3) } & 3.07 & $1.52^{* * *}$ & 3.40 \\
\hline & {$[2.71,3.41]$} & {$[1.41,1.62]$} & {$[2.98,3.82]$} \\
\hline \multirow[t]{2}{*}{ Payment delayed, for quantity delivered (payment2) } & 5.83 & $1.03^{* * *}$ & 6.86 \\
\hline & {$[5.42,6.23]$} & {$[0.84,1.22]$} & {$[6.44,7.27]$} \\
\hline \multirow{2}{*}{$\begin{array}{l}\text { Payment delayed, for quantity buyer sold to } \\
\text { customers, physically verifiable (payment } 3 \text { ) }\end{array}$} & 14.48 & $12.41^{* * *}$ & 14.93 \\
\hline & {$[14.22,14.75]$} & {$[11.13,13.70]$} & {$[14.80,15.05]$} \\
\hline \multirow{2}{*}{$\begin{array}{l}\text { Payment delayed, for quantity buyer sold to } \\
\text { customers, verifiable through bar coding (payment } 4 \text { ) }\end{array}$} & 18.51 & $15.76^{* * *}$ & 19.10 \\
\hline & {$[18.13,18.89]$} & {$[14.25,17.28]$} & {$[18.81,19.38]$} \\
\hline \multirow{2}{*}{$\begin{array}{l}\text { Payment delayed, for quantity buyer sold to } \\
\text { customers, not verifiable (payment5) }\end{array}$} & 23.96 & 24.44 & 23.85 \\
\hline & {$[23.43,24.48]$} & {$[22.03,26.85]$} & {$[23.48,24.23]$} \\
\hline$N$ (Number of observations) & 409 & 72 & 337 \\
\hline
\end{tabular}

Notes: Values are expressed in Ksh per bundle of vegetables. Confidence intervals (95\%) are shown in brackets; these were derived with the delta method. SM, supermarket; TC, traditional channel. ${ }^{*},{ }^{* *},{ }^{* * *}$ Differences in the mean WTA estimates between TC and SM farmers significant at the $10 \%, 5 \%$, and $1 \%$ level, respectively. 
The WTA values are expressed in Ksh per bundle of vegetables and can be interpreted as the average price premium farmers require in order to accept a particular attribute. The average price of vegetables in traditional marketing channels was Ksh 10 per bundle. Against this background the estimates in Table 2.6 appear quite high. It should be mentioned that the exact WTA values should not be over-interpreted, and their magnitude might have to be discounted somewhat, given the well-known hypothetical bias that stated preferences data often suffer from (Hensher et al., 2005). Moreover, mixed logit models tend to result in higher WTA values when estimated in preference space, as done here, than when estimated in willingness to pay space (Hole and Kolstad, 2012). However, there is no reason to believe that these issues affect some attributes more than others, so an unbiased relative ranking between the different attributes is possible.

Looking at the results for the pooled sample in Table 2.6, farmers require a price premium of Ksh $3.0(30 \%)$ to accept a contract with delivery to a nearby market. This WTA is relatively large and underlines that transportation and transaction costs - including opportunity costs of the farmer's time - are sizeable. The quantities typically delivered per transaction are small. Many of the farmers do not own a motor vehicle; they have to use public transportation or organize transport in other ways. The required premium for delivering to the supermarket stores in Nairobi is also high (Ksh 2.8). Interestingly, however, the WTA values for delivering to a nearby market and to Nairobi are very similar. Establishing more decentralized collection centers therefore might not substantially increase the rates of farmers' participation in contracts.

Having to sell in washed and sorted form requires an average price premium of $12 \%$ to compensate for the additional costs of post-harvest handling. For the condition to deliver their vegetables at specified dates, farmers demand a price increase of about $7 \%$. The WTA more ad-hoc orders through phone calls is higher (31\%), but still within the range of price premiums typically paid by supermarkets. Hence, these conditions related to post-harvest handling and timing of sales do not seem to be major hurdles for farmers to engage in supermarket contracts.

All payment mode attribute levels are associated with high WTA estimates, suggesting that these are the most critical features in the supermarket contracts from the farmers' perspective. For delayed payments, farmers require an average price premium of 58\%. This can be explained by liquidity constraints. Farmers need the cash to pay for household needs, 
outstanding bills, and farm inputs required to ensure high-quality production. Delayed payments also increase the subjectively felt risk of contract partners defaulting. The WTA gets much higher when payments are not based on what farmers delivered but on what the supermarket was able to sell to its customers. To some extent, this depends on the quality delivered. Yet there are also other factors that determine supermarket sales beyond the farmers' control. Hence, the marketing risk increases substantially.

When payment is based on the quantity the supermarket sold to its customers, verifiable through later inspection of the unsold quantity, farmers' mean WTA is a price premium of Ksh 14.5 per bundle (145\%). This attribute level (payment3) is the one that was actually observed in supermarket contracts in 2015. However, this WTA is much higher than contractual price premiums typically observed. This recent change in contractual design may therefore explain - at least partly - why some farmers dropped out of their contracts and why overall participation rates remain relatively low. ${ }^{5}$

For the other two attribute levels related to payment mode (payment4 and payment5), WTA estimates are still much higher (Table 2.6), which is likely due to issues of distrust. Verification through a barcoding system (payment4) could be a technical way of reducing the chances of opportunistic behavior, while also lowering transaction costs (in comparison to physical inspection). However, the WTA estimates suggest that farmers do not have full confidence in this technological alternative. When farmers are unable to verify the quantity supermarkets sold to customers (payment5), there may be concerns that the supermarkets cheat by underreporting actual sales.

A comparison of WTA estimates across the different attributes also sheds some light on farmers' risk perceptions. Shifting from a fixed time schedule of product delivery (timing2) to sales based on phone orders (timing3) introduces delivery risk. The required price premium for this delivery risk is relatively small, only about Ksh 2.4 per bundle of vegetables. The reason is probably that farmers expect phone orders to come at a certain frequency; otherwise there would be no reason for supermarkets to offer a contract. Switching from payment for the quantity delivered (payment2) to payment for the quantity sold (payment3) introduces demand risk with a higher price premium required, namely Ksh 8.7 per bundle. On the one

\footnotetext{
${ }^{5}$ We estimated additional models where we interacted the payment mode attribute levels with dummy variables for SM stayers and SM dropouts, both for the pooled sample and the two subsamples (Table A2.4 of Appendix to chapter 2). The small group of SM stayers has significantly less negative attitudes than the SM dropouts (and TC stayers) towards payments based on what supermarkets were able to sell.
} 
hand, there is no transparent quality grading system that could help farmers to assess possible rejection rates ex ante. On the other hand, unsold quantities in supermarket stores also depend on the efficiency of store management, which farmers are unable to influence. Switching from verified sales (payment3) to unverified sales (payment5) additionally introduces counterparty risk, for which a price premium of Ksh 9.5 per bundle is required. This high premium reflects the general distrust that many farmers have in supermarkets. This was also confirmed in focus group discussions. Studies in other settings also showed that farmers often distrust buyers that they do not know personally (Schipmann and Qaim, 2011).

The WTA estimates from the separate SM and TC models show significant differences between the two groups (Table 2.6). As one could expect, SM farmers have significantly lower WTA values for most of the attributes. This comparison suggests that modifications in contract design in terms of these attributes could affect farmers' participation rates positively.

\subsection{Conclusion}

We have carried out a choice experiment with vegetable farmers in Kenya to analyze how changes in contractual design may help to increase smallholder participation in supermarket contracting. The hypothetical contracts used in the choice experiment closely resembled those that Kenyan supermarkets actually apply to procure fresh vegetables from farmers. In these existing contract schemes, smallholder participation rates are relatively low and dropout rates are high.

The choice experimental data and mixed logit models were used to show that farmers have varied preferences for contracts. Most farmers seem to have rather negative attitudes towards contracting in general. Some of the contract design attributes make participation especially difficult. The contracts require farmers to deliver their vegetables to supermarket stores in Nairobi, which is associated with high transport and transaction costs, especially for farmers in more remote regions with poor infrastructure. Supermarkets also require farmers to wash, sort, and bundle the vegetables ready for supermarket shelves. These post-harvest operations are also associated with higher costs. Willingness to accept (WTA) estimates reveal that farmers require price premiums of $10-30 \%$ to compensate for the higher costs associated with these contract attributes. Nevertheless, these contract attributes related to the place and form 
of vegetable sales do not seem to be the main hurdles for more widespread smallholder participation.

The most critical contract attributes are related to payment mode. Farmers dislike delayed payments that are commonplace in contract schemes. Delayed payments can aggravate liquidity constraints and also increase the possible risk of defaulting. Current supermarket farmers have a mean WTA for delayed payments of $10 \%$, whereas TC farmers would require a price premium of close to $70 \%$ to accept this attribute. This is higher than typical price premiums paid in contract schemes, suggesting that delayed payments contribute to low participation rates by smallholders.

Also related to payment mode, supermarkets have recently changed the basis on which payments are made. Rather than paying for the quantity of vegetables delivered, farmers are now paid only for the quantity that the supermarket was able to sell to its customers. This change has further increased farmers' marketing risk. The choice experimental data suggest that farmers' mean WTA for this payment clause is around $145 \%$, again with higher values for TC than SM farmers. This recent change in payment mode seems to be an important factor in explaining the high farmer dropout rates observed. The analysis also revealed that distrust may be an issue. Farmers do not seem to believe supermarket statements about unsold quantities without the option to physically verify.

These results confirm that contractual design matters. They also suggest that better tailoring contracts to the conditions of smallholders can help to increase participation rates. Reducing payment delays, introducing standardized and verifiable quality grading systems, higher levels of transparency, and a fairer distribution of risk are all avenues that could make contracts more viable for smallholders. The analysis also showed that farmers marketing in groups have more positive attitudes towards contracts. Collective action in groups helps to reduce transportation and transaction costs and - through joint learning and peer pressure also can raise the quality and consistency of product supply. Hence, contracting farmer groups could possibly be a promising option.

Modifying contracts in the proposed directions could be useful to involve more smallholders. A relevant question is whether supermarkets themselves could also benefit from making contracts more smallholder-friendly. This will depend on the particular situation. Supermarkets in Nairobi currently seem to have sufficient supplies of leafy vegetables, so that increasing the supplier base may not be the top priority in the short run. However, when 
supermarkets continue to expand from the big cities to smaller towns and rural areas, and when fresh horticultural products shall gradually also be offered in these newly established stores outside of the big cities, then more procurement from smallholders may possibly become inevitable. Given observed supermarket growth rates in Africa, we argue that it is in the supermarkets' own interest to adjust contracts more flexibly to smallholder conditions.

Our results may also be useful for supermarket contracts in other developing countries. While the specific conditions differ to some extent, supermarkets in other countries of Africa, Asia, and Latin America also try to contract smallholders in order to source fresh products for sale to the growing urban middle classes (Berdegué et al,, 2005; Hernandez et al., 2007; Minten et al., 2009; Blandon et al., 2009b; Miyata et al., 2009; Michelson, 2013; Reardon and Timmer, 2014). Some of the results may also be relevant for contracting in the export industry, where marketing issues related to product quality, timing of supply, and payment mode also occur (Asfaw et al., 2010; Rosch and Ortega, 2014). However, due to higher quality standards in the export industry there are also other issues that we did not analyze here. For instance, export companies often provide inputs and technologies to contracted farmers, so problems of sideselling are much more relevant. More research is needed on how to improve the design of production and marketing contracts with smallholder farmers in different situations. 


\section{Appendix to Chapter 2}

Table A2. 1 Summary statistics by marketing channel (2015)

\begin{tabular}{|c|c|c|c|c|c|}
\hline \multirow[b]{2}{*}{ Variable } & \multicolumn{2}{|c|}{ SM farmers } & \multicolumn{2}{|c|}{ TC farmers } & \multirow[b]{2}{*}{$P$-value } \\
\hline & Mean & SD & Mean & SD & \\
\hline Farm size & 2.25 & 3.77 & 1.71 & 2.66 & 0.16 \\
\hline Household size & 4.56 & 1.92 & 4.08 & 1.68 & $0.04^{* *}$ \\
\hline Farm income & 842.41 & 189.41 & 328.09 & 515.16 & $0.00^{* * *}$ \\
\hline Off-farm income & 0.83 & 0.38 & 0.77 & 0.42 & 0.23 \\
\hline Total income & 1105.82 & 2078.99 & 439.22 & 517.58 & $0.00^{* * *}$ \\
\hline Irrigation & 0.86 & 0.35 & 0.69 & 0.47 & $0.00^{* * *}$ \\
\hline Vegetable area & 0.98 & 1.50 & 0.45 & 0.52 & $0.00^{* * *}$ \\
\hline Vegetable share & 0.63 & 0.30 & 0.52 & 0.32 & $0.01^{* * *}$ \\
\hline Group member & 0.85 & 0.36 & 0.86 & 0.34 & 0.72 \\
\hline Group marketing & 0.21 & 0.41 & 0.05 & 0.22 & $0.00^{* * *}$ \\
\hline Distance & 8.91 & 8.78 & 9.98 & 8.57 & 0.34 \\
\hline Credit access & 0.90 & 0.30 & 0.68 & 0.47 & $0.00^{* * *}$ \\
\hline Male & 0.93 & 0.26 & 0.84 & 0.37 & $0.05^{*}$ \\
\hline Age & 51.28 & 12.13 & 54.95 & 14.48 & $0.05^{* *}$ \\
\hline Education & 11.03 & 3.22 & 9.37 & 3.69 & $0.00^{* * *}$ \\
\hline No. of observations & 72 & & 337 & & \\
\hline
\end{tabular}

Notes: SM, supermarket; TC, traditional channel; SD, standard deviation for each sample. The last column shows $p$-values of a mean difference test between SM and TC farmers. ${ }^{*}$ significant at $10 \%$ level; ${ }^{*},{ }^{* *},{ }^{* * *}$ Significant at the $10 \%, 5 \%$, and $1 \%$ level, respectively. 


\section{Table A2. 2 Summary statistics by survey round}

\begin{tabular}{|c|c|c|c|c|c|c|c|c|c|c|c|c|}
\hline \multirow{3}{*}{ Variables } & \multicolumn{4}{|c|}{2008} & \multicolumn{4}{|c|}{2012} & \multicolumn{4}{|c|}{2015} \\
\hline & \multicolumn{2}{|c|}{$\mathrm{SM}(\mathrm{n}=133)$} & \multicolumn{2}{|c|}{$\mathrm{TC}(\mathrm{n}=269)$} & \multicolumn{2}{|c|}{$\mathrm{SM}(\mathrm{n}=85)$} & \multicolumn{2}{|c|}{ TC $(n=299)$} & \multicolumn{2}{|c|}{$\mathrm{SM}(\mathrm{n}=72)$} & \multicolumn{2}{|c|}{$\mathrm{TC}(\mathrm{n}=337)$} \\
\hline & Mean & SD & Mean & SD & Mean & SD & Mean & SD & Mean & SD & Mean & SD \\
\hline Farm size (acres) & 2.69 & 5.61 & 1.87 & 2.48 & 2.69 & 3.70 & 1.82 & 2.59 & 2.25 & 3.77 & 1.71 & 2.66 \\
\hline Vegetable area (acres) & 1.17 & 1.46 & 0.70 & 0.99 & 1.06 & 1.06 & 0.53 & 0.54 & 0.98 & 1.50 & 0.45 & 0.52 \\
\hline Male (dummy) & 0.93 & 0.25 & 0.88 & 0.32 & 0.79 & 0.41 & 0.64 & 0.48 & 0.93 & 0.26 & 0.84 & 0.37 \\
\hline Age (years) & 47.25 & 12.94 & 49.44 & 15.04 & 49.32 & 12.69 & 49.58 & 13.37 & 51.28 & 12.13 & 54.95 & 14.48 \\
\hline Education (years) & 10.30 & 3.15 & 8.72 & 4.05 & 10.66 & 3.14 & 9.26 & 3.56 & 11.03 & 3.22 & 9.37 & 3.69 \\
\hline
\end{tabular}

Notes: SM, supermarket; TC, traditional channel; SD, standard deviation for each sample. 
Table A2. 3 Summary statistics for farmers with different contracting history (2015)

\begin{tabular}{|c|c|c|c|c|c|c|c|c|}
\hline \multirow[b]{2}{*}{ Variable } & \multicolumn{2}{|c|}{ TC stayers } & \multicolumn{2}{|c|}{ SM stayers } & \multicolumn{2}{|c|}{ SM dropouts } & \multicolumn{2}{|c|}{ SM newcomers } \\
\hline & Mean & SD & Mean & SD & Mean & SD & Mean & SD \\
\hline Farm size & 1.57 & 2.66 & 2.37 & 3.56 & 2.41 & 2.54 & 2.14 & 3.99 \\
\hline Household size & 4.05 & 1.67 & 4.94 & 2.12 & 4.23 & 1.74 & 4.21 & 1.68 \\
\hline Farm income & 304.11 & 447.36 & 1323.35 & 2638.78 & 448.44 & 764.68 & 412.09 & 521.07 \\
\hline Off-farm income & 0.75 & 0.43 & 0.85 & 0.36 & 0.86 & 0.35 & 0.82 & 0.39 \\
\hline Total income & 413.44 & 485.47 & 1718.08 & 2848.18 & 568.58 & 645.22 & 558.00 & 637.28 \\
\hline Irrigation & 0.69 & 0.46 & 0.88 & 0.33 & 0.64 & 0.48 & 0.84 & 0.37 \\
\hline Vegetable area & 0.43 & 0.51 & 1.43 & 2.06 & 0.55 & 0.59 & 0.57 & 0.40 \\
\hline Vegetable share & 0.53 & 0.32 & 0.68 & 0.31 & 0.43 & 0.32 & 0.59 & 0.29 \\
\hline Group member & 0.88 & 0.33 & 0.85 & 0.36 & 0.80 & 0.40 & 0.84 & 0.37 \\
\hline Group marketing & 0.03 & 0.18 & 0.27 & 0.45 & 0.14 & 0.35 & 0.16 & 0.37 \\
\hline Distance & 9.93 & 8.71 & 8.09 & 6.40 & 10.21 & 7.90 & 9.63 & 10.51 \\
\hline Credit access & 0.67 & 0.47 & 0.97 & 0.17 & 0.77 & 0.43 & 0.84 & 0.37 \\
\hline Male & 0.83 & 0.37 & 1.00 & 0.00 & 0.89 & 0.31 & 0.87 & 0.34 \\
\hline Age & 54.28 & 14.51 & 51.74 & 12.08 & 58.64 & 13.89 & 50.87 & 12.32 \\
\hline Education & 9.16 & 3.77 & 11.06 & 3.62 & 10.44 & 3.05 & 11.00 & 2.87 \\
\hline No. of observations & 281 & & 34 & & 56 & & 38 & \\
\hline
\end{tabular}

Notes: TC, traditional channel; SM, supermarket; SD, standard deviation for each sample. 
Table A2. 4 Mixed logit models with interactions between payment mode attributes and farmers' contracting history

\begin{tabular}{|c|c|c|c|c|}
\hline & \multicolumn{2}{|c|}{ Pooled sample } & SM farmers & TC farmers \\
\hline \multicolumn{5}{|l|}{ Parameters } \\
\hline ASC & $0.89^{* * *}(0.26)$ & $0.95^{* * *}(0.27)$ & $0.99^{* *}(0.50)$ & $0.80^{* *}(0.35)$ \\
\hline Price & $0.33^{* * *}(0.03)$ & $0.34^{* * *}(0.03)$ & $0.25^{* * *}(0.05)$ & $0.33^{* * *}(0.03)$ \\
\hline Sales at a nearby market (place2) & $-1.08^{* * *}(0.24)$ & $-1.23^{* * *}(0.26)$ & $-0.39(0.40)$ & $-1.17^{* * *}(0.30)$ \\
\hline Sales at buyers' premise (place3) & $-0.82^{* * *}(0.24)$ & $-0.86^{* * *}(0.24)$ & $0.08(0.35)$ & $-1.04^{* * *}(0.28)$ \\
\hline Sold in washed and sorted form (form2) & $-0.35^{* *}(0.15)$ & $-0.33^{* *}(0.16)$ & $-0.38(0.24)$ & $-0.36^{*}(0.19)$ \\
\hline Sales as scheduled in contract (timing2) & $-0.19(0.21)$ & $-0.25(0.21)$ & $0.38(0.35)$ & $-0.33(0.33)$ \\
\hline Sales based on phone orders (timing3) & $-0.87^{* * *}(0.24)$ & $-0.90^{* * *}(0.25)$ & $-0.42(0.39)$ & $-1.21^{* *}(0.53)$ \\
\hline $\begin{array}{l}\text { Payment delayed, for quantity delivered } \\
\text { (payment2) }\end{array}$ & $-2.04^{* * *}(0.29)$ & $-1.79^{* * *}(0.29)$ & $0.61(0.42)$ & $-2.12^{* * *}(0.42)$ \\
\hline $\begin{array}{l}\text { Payment delayed, for quantity sold to } \\
\text { customers, physically verifiable (payment3) }\end{array}$ & $-4.70^{* * *}(0.52)$ & $-4.72^{* * *}(0.49)$ & $2.04^{* * *}(0.78)$ & $-4.98^{* * *}(0.88)$ \\
\hline $\begin{array}{l}\text { Payment delayed, for quantity sold to } \\
\text { customers, verifiable through bar coding } \\
\text { (payment4) }\end{array}$ & $-6.43^{* * *}(0.88)$ & $-5.91^{* * *}(0.62)$ & $-1.72^{* *}(0.83)$ & $-7.29^{* * *}(1.04)$ \\
\hline $\begin{array}{l}\text { Payment delayed, for quantity sold to } \\
\text { customers, not verifiable (payment5) }\end{array}$ & $-7.89^{* * *}(1.10)$ & $-7.75^{* * *}(1.13)$ & $3.23^{* * *}(0.93)$ & $-7.47^{* * *}(1.51)$ \\
\hline \multicolumn{5}{|l|}{ Interactions } \\
\hline Payment2 x SM stayers (dummy) & $2.75^{* * *}(0.56)$ & & $-1.28^{* *}(0.51)$ & \\
\hline Payment3 x SM stayers (dummy) & $2.46^{* * *}(0.68)$ & & $-1.48(0.90)$ & \\
\hline Payment4 x SM stayers (dummy) & $4.51^{* * *}(1.19)$ & & $3.30^{* * *}(1.21)$ & \\
\hline Payment5 x SM stayers (dummy) & $4.18^{* * *}(1.26)$ & & $-1.60(1.23)$ & \\
\hline Payment2 x SM dropouts (dummy) & & $-0.53(0.71)$ & & $-0.24(1.33)$ \\
\hline Payment3 x SM dropouts (dummy) & & $0.77(0.54)$ & & $1.27^{* *}(0.53)$ \\
\hline Payment4 x SM dropouts (dummy) & & $0.31(0.79)$ & & $1.30(0.87)$ \\
\hline Payment5 x SM dropouts (dummy) & & $-0.78(0.88)$ & & $1.20(2.00)$ \\
\hline \multicolumn{5}{|l|}{ Standard deviations } \\
\hline ASC & $2.20^{* * *}(0.22)$ & $2.22^{* * *}(0.20)$ & $1.49^{* * *}(0.32)$ & $2.22^{* * *}(0.30)$ \\
\hline Place2 & $1.06^{* * *}(0.28)$ & $1.24^{* * *}(0.24)$ & $0.50(0.88)$ & $-0.72(0.45)$ \\
\hline Place3 & $1.20^{* * *}(0.31)$ & $1.46^{* * *}(0.28)$ & $0.67(0.58)$ & $1.06^{* * *}(0.35)$ \\
\hline Form2 & $-0.22(0.19)$ & $-0.004(0.30)$ & $0.12(0.29)$ & $-0.05(0.36)$ \\
\hline Timing2 & $-0.67(0.51)$ & $-1.02^{* *}(0.44)$ & $-0.96(0.66)$ & $0.64(0.39)$ \\
\hline Timing3 & $1.84^{* * *}(0.36)$ & $1.94^{* * *}(0.34)$ & $0.22(0.56)$ & $-2.39^{* *}(1.11)$ \\
\hline Payment2 & $1.98^{* * *}(0.30)$ & $2.13^{* * *}(0.30)$ & $-0.49(0.50)$ & $2.05^{* *}(1.02)$ \\
\hline Payment3 & $1.32^{* *}(0.53)$ & $1.42^{* * *}(0.46)$ & $1.74^{* *}(0.82)$ & $0.65(1.55)$ \\
\hline Payment4 & $2.42^{* * *}(0.62)$ & $2.40^{* * *}(0.47)$ & $1.84^{* * *}(0.65)$ & $2.94^{* * *}(0.48)$ \\
\hline Payment5 & $3.20^{* * *}(0.83)$ & $3.45^{* * *}(0.86)$ & $2.08^{* * *}(0.79)$ & $2.63^{* * *}(0.81)$ \\
\hline $\mathrm{N}$ (Number of observations) & 7362 & 7362 & 1296 & 6066 \\
\hline Log likelihood at start & -1558.79 & -1598.41 & -339.67 & -1201.35 \\
\hline Log likelihood at convergence & -1371.50 & -1391.21 & -313.48 & -1038.48 \\
\hline Wald chi2 (15) & $186.21^{* * *}$ & $186.39^{* * *}$ & $89.71^{* * *}$ & $182.56^{* * *}$ \\
\hline Pseudo R2 & 0.29 & 0.28 & 0.23 & 0.32 \\
\hline
\end{tabular}


Table A2. 5 Mixed logit models with interactions between contract attributes and socioeconomic characteristics for SM farmers

\begin{tabular}{|c|c|c|c|c|c|}
\hline & \multicolumn{5}{|c|}{ Variables interacted with attribute levels } \\
\hline & (1) & (2) & (3) & (4) & (5) \\
\hline & $\begin{array}{c}\begin{array}{c}\text { Age of household head } \\
\text { (years) }\end{array} \\
\end{array}$ & $\begin{array}{c}\text { Education of household } \\
\text { head (years) }\end{array}$ & $\begin{array}{l}\text { Annual household } \\
\text { Income (000 Ksh) } \\
\end{array}$ & Kikuyu region (dummy) & $\begin{array}{c}\text { Group marketing } \\
\text { (dummy) }\end{array}$ \\
\hline \multicolumn{6}{|c|}{ Interacted with } \\
\hline ...Place2 & $0.002(0.03)$ & $0.27(0.19)$ & $9.82 \mathrm{e}-05(0.0002)$ & $0.01(0.71)$ & $-0.29(0.93)$ \\
\hline ...Place3 & $0.01(0.03)$ & $0.12(0.14)$ & $1.52 \mathrm{e}-05(0.0002)$ & $0.46(0.63)$ & $-0.20(0.92)$ \\
\hline ...Form2 & $-0.02(0.02)$ & $-0.04(0.08)$ & $7.92 \mathrm{e}-05(7.87 \mathrm{e}-05)$ & $0.57(0.40)$ & $-0.36(0.48)$ \\
\hline ...Timing2 & $0.01(0.03)$ & $-0.04(0.11)$ & $-0.0001(0.0001)$ & $0.04(0.54)$ & $0.48(0.80)$ \\
\hline ...Timing3 & $0.02(0.02)$ & $-0.10(0.15)$ & $-7.87 \mathrm{e}-05(0.0001)$ & $0.53(0.55)$ & $0.06(0.59)$ \\
\hline ...Payment2 & $-0.02(0.02)$ & $0.10(0.14)$ & $0.0003^{*}(0.0001)$ & $-0.53(0.58)$ & $0.04(0.74)$ \\
\hline ...Payment3 & $-0.01(0.04)$ & $0.13(0.25)$ & $0.0002(0.0002)$ & $-1.24(0.96)$ & $1.35(1.46)$ \\
\hline ...Payment4 & $0.04(0.05)$ & $-0.40(0.35)$ & $0.0002(0.0003)$ & $-1.73^{*}(0.90)$ & $1.70(1.59)$ \\
\hline ...Payment5 & $0.01(0.05)$ & $0.11(0.36)$ & $0.0001(0.0004)$ & $-2.13^{*}(1.14)$ & $3.01(2.36)$ \\
\hline \multicolumn{6}{|l|}{ Parameters } \\
\hline ASC & $0.96^{*}(0.50)$ & $1.17^{* *}(0.57)$ & $1.01^{* *}(0.51)$ & $1.10^{* *}(0.52)$ & $0.94^{*}(0.51)$ \\
\hline Price & $0.25^{* * *}(0.06)$ & $0.32^{* *}(0.13)$ & $0.26^{* * *}(0.06)$ & $0.26^{* * *}(0.05)$ & $0.26^{* * *}(0.06)$ \\
\hline Place2 & $-0.51(1.60)$ & $-3.63(2.52)$ & $-0.60(0.51)$ & $-0.45(0.49)$ & $-0.40(0.54)$ \\
\hline Place3 & $-0.67(1.48)$ & $-1.32(1.57)$ & $0.12(0.45)$ & $-0.08(0.45)$ & $0.13(0.56)$ \\
\hline Form2 & $0.52(1.01)$ & $-0.10(0.95)$ & $-0.49^{*}(0.28)$ & $-0.60^{* *}(0.29)$ & $-0.33(0.37)$ \\
\hline Timing2 & $-0.37(1.48)$ & $0.81(1.29)$ & $0.47(0.44)$ & $0.34(0.45)$ & $0.21(0.46)$ \\
\hline Timing3 & $-1.37(1.23)$ & $0.65(1.60)$ & $-0.32(0.44)$ & $-0.62(0.45)$ & $-0.46(0.52)$ \\
\hline Payment2 & $0.79(1.31)$ & $-1.30(1.70)$ & $-0.45(0.43)$ & $0.18(0.47)$ & $-0.13(0.46)$ \\
\hline Payment3 & $-2.22(2.35)$ & $-5.31(4.39)$ & $-3.34^{* * *}(1.23)$ & $-2.29^{* *}(0.94)$ & $-3.70^{*}(2.22)$ \\
\hline Payment4 & $-4.92(3.86)$ & $-0.21(2.43)$ & $-3.31^{* * *}(0.79)$ & $-2.24^{* *}(0.90)$ & $-4.04^{*}(2.35)$ \\
\hline Payment5 & $-4.65(3.58)$ & $-3.94(6.87)$ & $-4.50(3.07)$ & $-2.82^{* * *}(1.01)$ & $-4.76(3.66)$ \\
\hline
\end{tabular}




\section{Table A2.5. (continued)}

\begin{tabular}{|c|c|c|c|c|c|}
\hline \multicolumn{6}{|l|}{ Standard deviations } \\
\hline ASC & $1.57^{* * *}(0.39)$ & $1.73^{* * *}(0.60)$ & $1.57^{* * *}(0.56)$ & $1.57^{* * *}(0.29)$ & $1.55^{* * *}(0.57)$ \\
\hline Place2 & $0.84(0.60)$ & $-1.38(1.30)$ & $0.91(0.72)$ & $0.67(0.54)$ & $0.93(0.99)$ \\
\hline Place3 & $0.82(0.97)$ & $1.49(1.26)$ & $-0.99(1.25)$ & $0.46(0.90)$ & $0.88(0.98)$ \\
\hline Form2 & $0.07(0.39)$ & $-0.69(0.75)$ & $0.08(0.37)$ & $0.09(0.27)$ & $0.27(0.43)$ \\
\hline Timing2 & $0.94(0.77)$ & $-1.20(0.95)$ & $1.24(0.85)$ & $-0.94(0.71)$ & $1.31(1.24)$ \\
\hline Timing3 & $-0.23(0.46)$ & $0.72(0.74)$ & $-0.04(2.16)$ & $0.15(0.26)$ & $0.14(0.92)$ \\
\hline Payment3 & $1.80(1.17)$ & $2.72(1.96)$ & $1.94^{*}(1.05)$ & $1.90^{*}(1.08)$ & $2.35(2.18)$ \\
\hline Payment4 & $1.64(2.10)$ & $-3.65(2.46)$ & $1.48(0.92)$ & $-1.86^{* *}(0.74)$ & $2.11(1.56)$ \\
\hline Payment5 & $2.32(2.59)$ & $2.69(2.38)$ & $2.51(2.81)$ & $1.68^{* *}(0.76)$ & $-1.74(3.49)$ \\
\hline LL at start & 347.68 & 346.00 & 347.62 & 345.40 & 343.53 \\
\hline LL at convergence & 320.86 & 315.93 & 318.45 & 316.48 & 315.92 \\
\hline Wald chi² $(20)$ & $67.58^{* * *}$ & $33.34^{* * *}$ & $108.33^{* * *}$ & $87.67^{* * *}$ & $62.97^{* * *}$ \\
\hline
\end{tabular}

Notes: Coefficient estimates are shown with standard errors in parentheses (clustered by individual). The binary dependent variable is marketing channel (contract) choice. $\mathrm{N}=1296$. LL, log likelihood; Place2, nearby market; Place3, buyers' premise; Form2, sold in washed and sorted form; Timing2, sales at times specified in the contract; Timing3, sales based on phone orders; Payment2, payment delayed, for quantity delivered. Payment3, payment delayed, for quantity sold to customers, physically verifiable; Payment4, payment delayed, for quantity sold to customers, verifiable through bar coding; Payment5, payment delayed, for quantity sold to customers, not verifiable. For place of sale, the reference is "farm gate" (place1). For form of sale, the reference is "sold as harvested" (form1). For time of sale, the reference is "at any time" (timing1). For payment mode, the reference is "payment immediate, based on quantity delivered" (payment1). ASC, alternative specific constant (refers to traditional channel without contract); SM, supermarket. *

${ }^{* *},{ }^{* * *}$ Significant at the $10 \%, 5 \%$, and $1 \%$ level, respectively. 
Table A2. 6 Mixed logit models with interactions between contract attributes and socioeconomic characteristics for TC farmers

\begin{tabular}{|c|c|c|c|c|c|}
\hline & \multicolumn{5}{|c|}{ Variables interacted with attribute levels } \\
\hline & (1) & (2) & (3) & (4) & (5) \\
\hline & $\begin{array}{c}\begin{array}{c}\text { Age of household head } \\
\text { (years) }\end{array} \\
\end{array}$ & $\begin{array}{c}\text { Education of household } \\
\text { head (years) }\end{array}$ & $\begin{array}{l}\text { Annual household } \\
\text { Income (000 Ksh) } \\
\end{array}$ & Kikuyu region (dummy) & $\begin{array}{c}\text { Group marketing } \\
\text { (dummy) }\end{array}$ \\
\hline \multicolumn{6}{|c|}{ Interacted with } \\
\hline ..Place2 & $-0.04^{* *}(0.02)$ & $0.15^{* *}(0.06)$ & $2.99 \mathrm{e}-05(0.0004)$ & $0.54(0.44)$ & $-2.01(1.46)$ \\
\hline ...Place3 & $-0.002(0.02)$ & $-0.04(0.06)$ & $0.0001(0.0003)$ & $0.21(0.43)$ & $-0.50(0.92)$ \\
\hline ...Form2 & $-0.01(0.01)$ & $-0.01(0.05)$ & $0.0003(0.0002)$ & $0.23(0.30)$ & $-0.28(0.81)$ \\
\hline ...Timing2 & $-0.01(0.01)$ & $0.09^{* *}(0.05)$ & $-0.001^{* *}(0.0003)$ & $-0.27(0.38)$ & $1.48^{*}(0.87)$ \\
\hline ...Timing3 & $0.04(0.03)$ & $-0.08(0.09)$ & $-0.0003(0.0006)$ & $0.33(0.56)$ & $-0.20(1.42)$ \\
\hline ...Payment2 & $0.01(0.02)$ & $0.03(0.07)$ & $0.0007^{*}(0.0004)$ & $-0.52(0.52)$ & $0.71(1.29)$ \\
\hline ...Payment3 & $0.02(0.02)$ & $-0.01(0.08)$ & $0.0001(0.0005)$ & $0.17(0.55)$ & $1.98(1.58)$ \\
\hline ...Payment4 & $0.03(0.03)$ & $0.01(0.12)$ & $-0.002^{* *}(0.0009)$ & $-0.83(1.11)$ & $1.59(1.59)$ \\
\hline ...Payment5 & $0.03(0.04)$ & $0.17(0.17)$ & $-0.001(0.001)$ & $-4.89^{* * *}(0.99)$ & $-0.13(2.64)$ \\
\hline \multicolumn{6}{|l|}{ Parameters } \\
\hline ASC & $0.85^{* *}(0.35)$ & $0.75^{* *}(0.32)$ & $0.80^{* *}(0.32)$ & $0.82^{* * *}(0.31)$ & $0.79^{* *}(0.32)$ \\
\hline Price & $0.35^{* * *}(0.04)$ & $0.35^{* * *}(0.04)$ & $0.36^{* * *}(0.05)$ & $0.34^{* * *}(0.04)$ & $0.36^{* * *}(0.04)$ \\
\hline Place2 & $0.50(0.82)$ & $-2.64^{* * *}(0.74)$ & $-1.31^{* * *}(0.48)$ & $-1.49^{* * *}(0.38)$ & $-1.39^{* * *}(0.31)$ \\
\hline Place3 & $-1.13(0.96)$ & $-0.72(0.67)$ & $-1.23^{* * *}(0.41)$ & $-1.19^{* * *}(0.34)$ & $-1.24^{* * *}(0.32)$ \\
\hline Form2 & $0.01(0.70)$ & $-0.28(0.53)$ & $-0.51^{* *}(0.24)$ & $-0.41^{*}(0.24)$ & $-0.30(0.22)$ \\
\hline Timing2 & $0.20(0.80)$ & $-1.27^{* *}(0.51)$ & $-0.70^{* *}(0.28)$ & $-0.20(0.27)$ & $-0.39(0.26)$ \\
\hline Timing3 & $-3.27^{* *}(1.33)$ & $-0.36(0.86)$ & $-0.94^{* *}(0.38)$ & $-1.20^{* * *}(0.43)$ & $-1.06^{* * *}(0.37)$ \\
\hline Payment2 & $-2.74^{* *}(1.23)$ & $-2.65^{* * *}(0.82)$ & $-2.70^{* * *}(0.40)$ & $-2.07^{* * *}(0.38)$ & $-2.46^{* * *}(0.39)$ \\
\hline Payment3 & $-6.36^{* * *}(1.35)$ & $-4.92^{* * *}(1.05)$ & $-5.15^{* * *}(0.99)$ & $-4.73^{* * *}(0.45)$ & $-5.55^{* * *}(0.77)$ \\
\hline Payment4 & $-8.18^{* * *}(1.96)$ & $-6.77^{* * *}(1.34)$ & $-6.23^{* * *}(1.16)$ & $-6.76^{* * *}(0.95)$ & $-6.51^{* * *}(0.78)$ \\
\hline Payment5 & $-10.16^{* * *}(2.48)$ & $-9.77^{* * *}(2.64)$ & $-8.75^{* * *}(1.57)$ & $-6.47^{* * *}(0.89)$ & $-9.86^{* * *}(1.30)$ \\
\hline
\end{tabular}




\section{Table A2.6. (continued)}

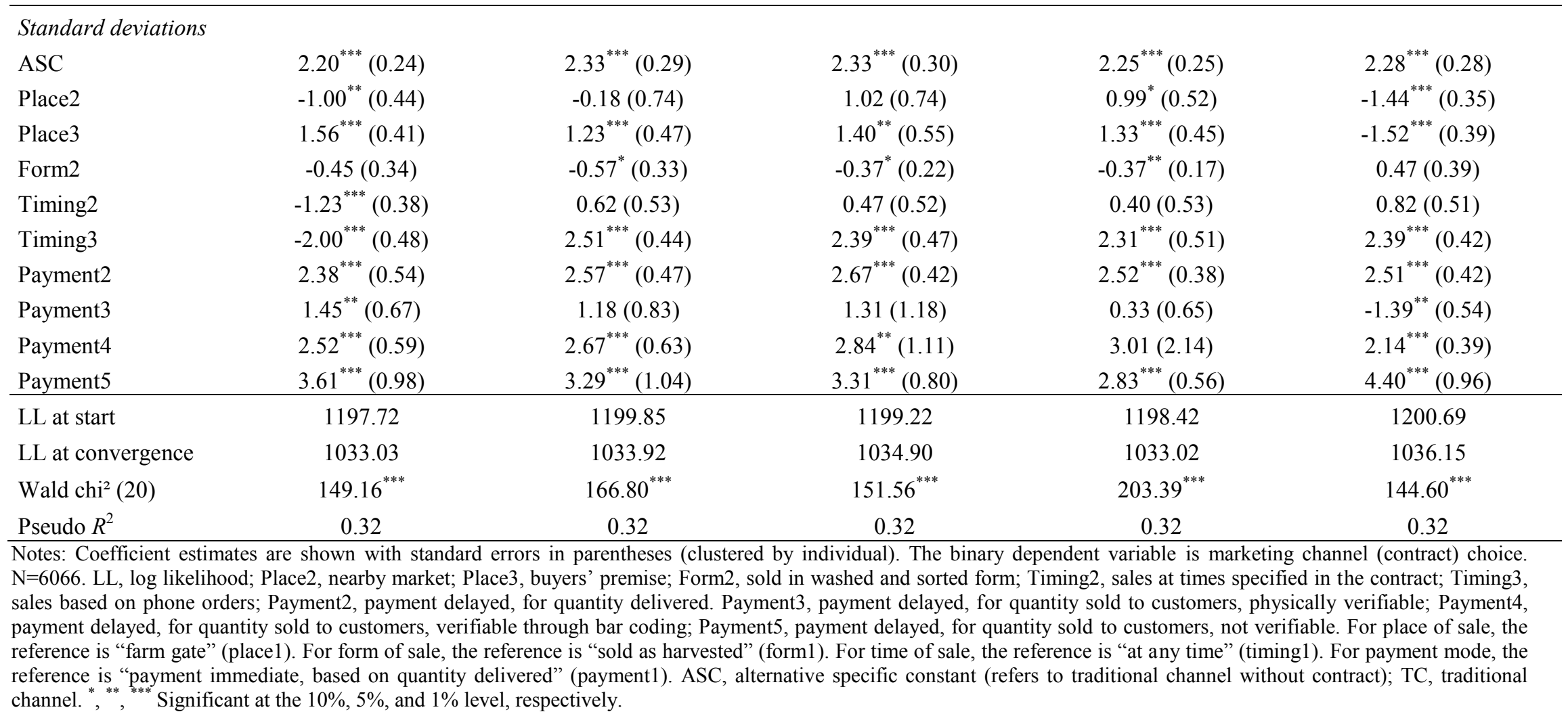




\title{
3 Supermarket Contracts, Income, and Changing Diets of Farm Households: Panel Data Evidence from Kenya ${ }^{6}$
}

\begin{abstract}
In many developing countries, supermarkets are increasingly replacing traditional markets as preferred points of food purchases in urban areas. This has welfare implications on smallholder farmers that supply supermarkets. While previous studies have analyzed the welfare effects of smallholder participation in supermarket channels, many have focused on economic effects alone. Very little is known about the effects on farm household diets. Besides, most existing studies that have looked at economic effects used cross-sectional data that are limited in controlling for time-invariant differences between supermarket and traditional channel farmers. This study uses panel data from vegetable farmers in Kenya to examine the effects of supermarket contracting on farm household income and diets. Supplying supermarkets has increased household income by $66 \%$, and is associated with $8 \%$ higher consumption of calories, as well as better dietary diversity, and higher levels of zinc consumption. Using these results for simple simulations suggests that wider participation of smallholders in supermarket channels could reduce the prevalence of undernourishment by $8 \%$ and the prevalence of zinc deficiency by $12 \%$. Hence, enhancing smallholder market access could significantly contribute to reduction of undernourishment and micronutrient malnutrition and to increases in the incomes of rural farm households.
\end{abstract}

\subsection{Introduction}

For most agro-dependent economies, smallholder agriculture contributes significantly to the aggregate agricultural output. Agricultural production is dominated by smallholder farms that employ majority of rural populations. Statistics for developing countries show that $70 \%$ of human populations reside in rural areas and rely on agriculture as main source of livelihood (FAO, 2014; World Bank, 2016). Incidences of poverty and hunger remain high in the rural areas of many developing countries. Global statistics also show that about 800 million people are hungry while another 2 billion suffer from micronutrients deficiencies - largely rural populations (Horton and Lo, 2013; IFPRI, 2016).

${ }^{6}$ This chapter is sole-authored by the doctoral student. 
Alternative employment opportunities outside of agriculture are also limited for the rural populations in developing countries where manufacturing sector is less vibrant (Wiggins et al., 2010). Hence, smallholder farming takes the center stage in creating employment and rural development, and reducing poverty and hunger (World Bank 2007; Gautam et al., 2016). For sustainability of the emerging high-value chains and of accruing benefits, efforts to enhance smallholder production capacities and market access are important (Hazell et al., 2010). From poverty reduction and equity perspective, access to these markets would not only increase incomes, reduce poverty and widening inequalities, hunger and malnutrition, but also have wider spillover effects to the rural non-farm sector. This could generate off-farm employment and stimulate growth of the rural economy.

Market access is one major constraint to the viability of smallholder farming due to the relatively small-scale farm operation and the high transaction costs occasioned by market imperfections in developing countries (Hazell et al., 2010; Escobal et al., 2012). Contract farming is one of the pathways to widening smallholder farmers' access to high-value markets. This could be in the form of production or marketing contracts that are widespread in the domestic and export markets for horticultural products in many developing countries (Otsuka et al., 2016). Contract farming stabilizes prices and volumes traded while offering assured market to farmers thus could potentially increase incomes of contracted farmers.

Increased globalization has expanded trade in processed and fresh foods across countries along with dynamic transformation of agri-food systems, often with far-reaching implications on agricultural production (Jenkins, 2004; Hazell et al., 2010). These developments have led to increased integration of the food marketing systems and spread of supermarkets in what has been described by Reardon et al (2012) as "supermarket revolution". The spread first began in Central America before spreading to Asia, and currently beginning to take shape in SubSaharan Africa. Supermarkets are increasingly replacing traditional retailers and wet markets as preferred shopping outlets by largely urban populations (Qaim, 2017). This is occasioned by rising incomes, urbanization and emerging urban middle classes, dynamic tastes and preferences of consumers, growing demand for variety of foods, and desire for shopping convenience among the more affluent segments of the populations (Reardon and Timmer, 2014; Tschirley et al., 2015). These demand and supply side factors have significantly contributed to nutrition transition in developing countries (Mergenthaler et al., 2009; Gómez, and Ricketts, 2013). 
The rapid supermarket growth has broad implications on food retailing and access to variety of foods, and farm production of fresh foods demanded by supermarkets. Two strands of literature analyze the welfare effects of supermarkets. On the one hand, the impacts (through supermarket purchases) are analyzed in terms of household or individual level nutrition effects of food purchases from supermarkets (Asfaw, 2008; Popkin, 2014; Umberger et al., 2015; Kimenju et al., 2016). Supermarkets stock diverse nutritious foods as well as energydense and highly processed foods.

On the other hand, from the supply side, welfare effects of supermarket contracting on farm households are analyzed. Existing studies focus on farm profits, farm productivity, assets accumulation, on-farm and off-farm employment, and changes in gender roles among other issues (Miyata et al., 2009; Neven et al., 2009; Rao and Qaim, 2011; Michelson, 2013; Rao and Qaim, 2013; Chege et al., 2015). Hence, supermarket growth could contribute to the modernization of the small farm sector and widen market access by smallholder farmers, with far reaching welfare implications. This study contributes to the latter strand of literature with a focus on contractual arrangements between rural smallholder farmers and supermarkets. Supermarkets are modernizing their food procurement systems and increasingly sourcing FFVs directly from farmers (Chege et al., 2015). It is important to understand how the spread of supermarkets affect welfare of contracted farm households given the dynamic participation in such high value channels.

While previous studies have analyzed the welfare effects of smallholder participation in supermarket channels, many have focused on economic effects alone. Very little is known about the effects on farm household diets. Besides, most existing studies that have looked at economic effects used cross-sectional data that yield potentially biased results due to endogeneity problems. This study fills the literature and knowledge gap on the effects of supermarket contracting on household incomes and diets using panel data from a sample of vegetable farmers of Central Kenya. The study first analyzes the effects on household income before analyzing the effects on household diets - in terms of dietary diversity, as well as calories and micronutrient (iron, zinc and vitamin A) consumption. The hypotheses are that supermarket contracting increases household incomes, calories and micronutrients consumption, and dietary diversity.

Recent studies show that resource-constrained smallholder farmers are excluded from highvalue markets due to the stringent consistency, timeliness, volumetric, food safety and quality requirements, and the costly on-farm investment to meet the requirements (Anderson et al., 
2015; Chege et al., 2015). This has led to high drop-out rates in the supermarket channels, also partially attributed to unfavorable contractual arrangements that expose farmers to marketing risks (Ochieng et al., 2017). However, the farmers that overcome the hurdles are expected to benefit significantly from such marketing arrangements.

\subsection{The Study Context}

Kenya's economy is largely dependent on agriculture as a foreign exchange earner. The sector contributes significantly to the gross domestic product (GDP) and employs majority of the rural populations (Olwande et al., 2015). Currently, Kenya's human population stands at 46 million and is estimated to increase by 3\% by year 2030 (PRB, 2017). About 70\% of the population reside in rural areas and rely on smallholder agriculture as main source of livelihood, on 5\% of rural farmlands (Muyanga and Jayne, 2015). Poverty and prevalence of undernourishment and micronutrient malnutrition remains widespread particularly in the rural areas of Kenya (KNBS, 2008; RoK, 2012).

Hence, smallholder agriculture could significantly contribute to poverty reduction and improved food security among rural farm households, and enhance growth of the rural economy in Kenya. As earlier mentioned, contract farming is one of the pathways to widen smallholder access to markets while reducing transaction costs when engaging with smallholder farmers. In Kenya, it is widely practiced in both the domestic (e.g. supermarkets) and export markets for horticultural products (Okello and Swinnton, 2007; Asfaw et al., 2009; Neven et al., 2009). Kenya ranks second after South Africa with respect to growth of supermarkets that currently account for $10 \%$ of national retail and $20 \%$ of grocery sales in urban areas (Planet Retail, 2017).

Supermarkets offer variety of fresh and processed foods to consumers in Kenya and are also modernizing their food procurement systems in the wake of food safety and quality concerns to procure FFVs directly from farmers. This initially involved contracting medium and largescale farmers that could meet the stringent volumetric, timeliness, and quality requirements. However, supermarkets began contracting smallholder farmers as they expanded to other smaller towns (Chege et al., 2015). Such contracts provide opportunity for smallholder farmers to participate in such rewarding but often demanding high-value markets. 


\subsection{Materials and Methods}

\subsubsection{Study Area}

This study focuses on smallholder farmers of Kiambu County of Central Kenya. Kiambu is one of the high potential regions of Kenya with favorable climatic conditions for agricultural production. Farmers in the region practice mixed farming, cultivating staples and cash crops, and rearing livestock on small pieces of lands. Household survey was conducted in Kikuyu, Limuru, and Githunguri areas of Kiambu County.

The County provides appropriate setting for this study for the following reasons. First, the region borders the capital city where demand for FFVs is increasing due to growing human populations and expansion of satellite towns (Ayieko et al., 2005). This presents marketing opportunity for vegetable farmers. Second, the region is densely populated, with the rural households mainly engaged in farming as the main source of livelihood (KNBS, 2008). Poverty rate and prevalence of undernourishment and micronutrient deficiencies is high in rural areas (KNBS, 2008). Third, Kiambu is one of the major FFVs producing regions of Kenya, and a major source of FFVs for the supermarkets in Nairobi (Neven et al., 2009; Ochieng et al., 2017). Lastly, the perishable nature of FFVs and volatile prices across seasons presents a unique marketing problem to farmers, which substantially influence farm profits. Hence, it is important to analyze the effects of supermarket contracting on farm household income and diets.

\subsubsection{Data Collection}

This study builds on a panel survey conducted over several years. Stratified random sampling procedure was employed to randomly sample 402 farmers from 31 administrative locations within Kiambu in year 2008 (Rao and Qaim, 2011). The sample comprised traditional channel (TC) and supermarket (SM) channel farmers. Face-to-face interviews were conducted using a structured questionnaire. Subsequent follow-up surveys were carried out in years 2012 and 2015. Table A2.2 of appendix to chapter 2 provides a summary of characteristics of SM and TC farmers by survey rounds. Table 3.1 provides a summary of the farmers surveyed over the years. 
Table 3. 1 Number of farm households interviewed

\begin{tabular}{lccc}
\hline Farmers & $\mathbf{2 0 0 8}$ & $\mathbf{2 0 1 2}$ & $\mathbf{2 0 1 5}$ \\
\hline Supermarket farmers & 133 & 85 & 72 \\
Traditional channel farmers & 269 & 299 & 327 \\
\hline Total & 402 & 384 & 409 \\
\hline
\end{tabular}

The breakdown by group of farmers in Table 3.1 shows how the number of contracted (supermarket) farmers declined over time. It is important to mention that 9 farm households interviewed in 2015 are excluded from the following analysis due to incomplete data. Respondents were the household heads, their spouses or household members responsible for vegetable production and marketing, and the persons responsible for food preparation in the household (for the nutrition section).

\subsubsection{Data}

\section{Measuring household income}

This study exploits unbalanced panel data from all the three rounds of survey to analyze effect of supermarket contracting on farm household income. The questionnaire included sociodemographic characteristics of the farm households, focusing on farm production and marketing activities. In particular, a detailed section on vegetable production and supermarket contracts was included. These data allowed for computation of annual household incomes. Farm income was computed from crop and livestock revenues and corresponding costs incurred by the farm enterprises. Off-farm income comprised earnings from off-farm and nonfarm activities including remittances. These estimates of household income in all the survey rounds were adjusted for inflation using consumer price indices.

\section{Measuring calorie and micronutrient consumption}

Nutrition related questions were only included in the 2012 and 2015 survey rounds so that effects of supermarket contracting on household diets are analyzed using unbalanced panel data from the two survey rounds. The questionnaire detailed types and quantities of foods consumed from own production, gifts, and purchases by the households for more than 180 food items based on a 7-day recalls. This allowed for computation of quantities calories (energy) and micronutrients consumed by the households. Calorie consumption is a measure 
of access to adequate quantities of energy and foods for healthy living (FAO, 2001). Household dietary diversity was computed using a score as discussed below and is a robust indicator of household food access due to its positive and significant association with all measures of calorie consumption (Leroy et al., 2015).

The weekly quantities of foods consumed were converted into nutrient equivalents per 100 grams using food conversion tables for Kenya, while correcting for edible portions of food (Sehmi, 1993). The daily consumption estimates were determined by dividing the weekly calories and micronutrients consumed were divided by 7 . These daily estimates were further divided by adult equivalents (AE) for Kenya to obtain the quantities consumed per AE, so that comparisons between households are possible. The AE accounts for age and levels of physical activity of each household member.

We accounted for micronutrient losses from food preparation that affects nutrient availability (Bognár, 2002), and issues of bioavailability that depend on diets as well as inhibitors or enhancers of zinc and iron absorption by the body. Micronutrient analysis assumed iron bioavailability of $5 \%$, which is within suggested range of $5 \%$ to $15 \%$ (WHO and FAO, 2004) and zinc bioavailability of $15 \%$, assuming unrefined cereal based diets as common in Kenya (IZiNCG, 2004; WHO and FAO, 2004). Calorie and micronutrient deficiencies are determined by comparing the estimated consumption levels against the prescribed standard levels of $15 \mathrm{mg}$ of zinc, $18.3 \mathrm{mg}$ of iron, and $625 \mu \mathrm{g}$ retinol equivalent (RE) of vitamin A per $\mathrm{AE}$ and day. For calories, daily intake of $3000 \mathrm{Kcal}$ per AE and day is recommended for moderately active male adults in Kenya (WHO and FAO, 2004). A household is undernourished if the consumption level falls below $80 \%$ of the recommended level, meaning $2400 \mathrm{Kcal}$ per AE and day (FAO et al., 2001).

\section{Measuring household dietary diversity}

Household dietary diversity provides the general overview of nutritional status of the household (Leroy et al., 2015). Twelve food groups were used to calculate household dietary diversity score (HDDS). The groups comprised: vegetables; white tubers and roots; cereals; legumes; nuts and seeds; fruits; oils and fats; meat; fish and fish products; milk and dairy products; eggs; sweets and sugars; condiments, spices and beverages. Scores were assigned using a count of food groups consumed in the reference period as done in other nutritionrelated studies (Jones et al., 2014; Herforth and Ballard, 2016; Koppmair et al., 2017). HDDS can also be an indicator of dietary quality when computed using 9 food groups that exclude 
energy dense yet micronutrient poor food groups such a fat and oils, condiments, spices and beverages, and sweets and sugars (Sibhatu et al., 2015). This provides a snapshot of micronutrient density of the diets a well a robustness check on the estimations a will be shown in the results section.

\subsubsection{Estimation Procedure}

This section discusses the model specifications used to analyze the effects of supermarket contracting on household income and diets. A binary treatment variable (supermarket participation) in all the specifications assumes a value of one if the farmer is contracted by supermarkets and zero if not. The dietary outcomes refer to the household daily consumption of calorie, zinc, iron, and vitamin A per AE, and dietary diversity. Considering the panel structure of the data, we use random effects (RE), fixed effects (FE) and ordinary least squares (OLS) estimators for analysis. Household income or dietary outcomes are regressed on supermarket participation (dummy) while controlling for other factors that may also influence income and diets as shown in the specification below:

$Y_{i t}=\gamma S M_{i t}+\beta X_{i t}+\delta Z_{i}+\alpha_{i}+\mathrm{u}_{i t}$

where $\mathrm{Y}$ is either household income, calorie and micronutrients consumed per AE, or dietary diversity score. SM is the treatment variable. Subscripts index household $i=1,2, \ldots, N$ and time, $t=1,2, \ldots, T . X_{i}$ are the time variant characteristics whereas $Z_{i}$ are individual timeinvariant characteristics. $\alpha_{i}$ captures unobserved characteristics, independent and identically distributed - IDD $\left(0, \sigma_{\alpha}{ }^{2}\right)$ and the error term, $u_{i t}$ is IID $\left(0, \sigma_{u}{ }^{2}\right)$ both independent of each other and among themselves (Wooldridge, 2010). The hypothesis is that supplying supermarkets improve income, calorie and micronutrients consumption, and household dietary diversity, that is $\boldsymbol{\gamma}>0$.

The other controls $\left(X_{i}\right)$ are; age, gender, and education level of the household head, farm size, and household size. These factors may influence farmer participation in supermarket channels. For example, age and education level of farmers influence access to market information, managerial abilities, and farmers' willingness to contract or adopt of production technologies. Farm size is a proxy for farm household wealth status whereas household size (per adult equivalent) indicates availability of family labor, which is important for laborintensive production and post-harvest handling activities such as of FFVs. Supermarket 
contracting could affect participation in off-farm activities. Including region dummies captures any heterogeneity across the regions. However, there may be other unobserved factors (or differences) between farm households that influence incomes besides the aforementioned factors e.g. farmers' entrepreneurial skills and motivation, and location specific factors (climate, elevation, and soils that favor crop production).

The unobserved heterogeneity between SM and TC farmers may yield biased estimates. Fixed effects estimator controls for this, providing unbiased estimates. For the household income model, the $P$-value for the Hausman test is significant so that the null hypothesis that the difference in the coefficients is not systematic is rejected (Hausman, 1978). Hence, FE estimator is appropriate as shown in the following discussion.

For the dietary outcome models, the $P$-values for the Hausman test are insignificant so that the null hypothesis that the differences in the coefficients are not systematic cannot be rejected. Hence, RE estimator is appropriate. Breusch-Pagan test also confirmed that OLS specification is not appropriate. Both RE and OLS estimates are shown in the following empirical results section. The RE estimator does not control for unobserved heterogeneity of the farmers. Individual regressors are assumed exogenous (not correlated with individual effects). Hence, the treatment coefficients are interpreted as associations between supermarket contracting and household diets.

Beyond the Hausman test, RE estimator is appropriate in this case for two reasons. First, only two rounds of panel data is available for dietary outcome estimations such that using FE estimator would halve the degrees of freedom. Consequently, the tails of t-distribution thicken, implying that the coefficients are estimated with greater uncertainty (Cameron and Trivedi, 2004; Townsend et al., 2013). Secondly, there is little within-group variation in the covariates, meaning the covariates would be highly correlated with the fixed effects thereby rendering FE estimator inefficient (Wooldridge, 2010; Bell and Jones, 2015).

We perform simple simulations to assess the possible significance of the magnitude of the treatment effects on dietary outcomes by adding the mean coefficients of the treatment variable to the current consumption levels and then re-estimating the levels of calorie and micronutrient deficiency. This way, we are able to assess the economic relevance of the magnitudes of the coefficients interpreted. 


\subsection{Results and Discussion}

\subsubsection{Farm and Household Characteristics}

Table 3.2 provides a summary of farm and household characteristics from pooled sample (2008-2015). The SM and TC farmers differ in most of the characteristics. Majority of the farm households are male-headed. The household heads are about 51 years of age, with about nine years of schooling. The average farm size is about 2 acres. The average farm household comprises three persons (adult equivalent). Detailed descriptive statistics by group of farmers and survey rounds are in Table A2.2 of appendix to chapter 2.

Table 3. 2 Characteristics of the farmers (pooled sample)

\begin{tabular}{lccc}
\hline Variable & Full sample & SM farmers & TC farmers \\
\hline Total income (1000 ksh) & $436.32(763.05)$ & $749.36^{* * *}(1294.49)$ & $335.01(442.85)$ \\
Male household head (dummy) & $88.03(32.48)$ & $83.79^{* * *}(24.17)$ & $86.16(34.55)$ \\
Age of household head (years) & $51.74(14.09)$ & $49.60(12.85)$ & $52.43(14.40)$ \\
Education level of farmer (years) & $9.48(3.75)$ & $10.54^{* * *}(3.18)$ & $9.14(3.86)$ \\
Off-farm income (dummy) & $65.35(47.61)$ & $72.76^{* * *}(44.60)$ & $62.95(48.32)$ \\
Farm size (acres) & $1.98(3.10)$ & $2.62^{* * *}(4.69)$ & $1.78(2.34)$ \\
Household size (AE) & $2.59(1.18)$ & $2.93(1.15)$ & $2.48(1.16)$ \\
N (number of observations) & 1186 & 290 & 896 \\
\hline Notes: values are means with standard deviation in parentheses; SM, supermarket; TC, traditional channel; Ksh, Kenya shillings; \\
AE, Adult equivalent; ${ }^{*},{ }^{* * * *}$ Mean values between SM and TC farmers are statistically significant at the 1\% level.
\end{tabular}

Table 3.3 presents a summary of the household dietary indicators by marketing channels from pooled sample (2012-2015). SM farmers consume 3\% more calories than TC farmers and are less undernourished by a similar magnitude. The households have an average dietary diversity score of 8.77 , a sign of access to adequate quantities of food. More than half of the sampled households are iron deficient. Overall, the differences in the estimates between SM and TC farmers are not statistically significant. Hence, the two groups are comparable. 
Table 3. 3 Nutrition indicators by marketing channels

\begin{tabular}{|c|c|c|c|c|c|c|}
\hline \multirow[b]{2}{*}{ Variable } & \multicolumn{2}{|c|}{ Full sample } & \multicolumn{2}{|c|}{ SM farmers } & \multicolumn{2}{|c|}{ TC farmers } \\
\hline & Mean & SD & Mean & SD & Mean & SD \\
\hline Calorie consumption (kcal/day/AE) & 3342.96 & 1152.58 & 3416.06 & 1213.30 & 3324.65 & 1137.14 \\
\hline Prevalence of undernourishment (\%) & 19.13 & 39.36 & 17.20 & 37.86 & 19.62 & 39.74 \\
\hline Vitamin A consumption ( $\mu \mathrm{g}$ RE/day/AE) & 1420.37 & 930.48 & 1402.74 & 768.80 & 1424.78 & 967.23 \\
\hline Prevalence of vitamin A deficiency (\%) & 12.63 & 33.24 & 11.47 & 31.96 & 12.92 & 33.57 \\
\hline Iron consumption (mg/day/AE) & 18.81 & 8.95 & 18.55 & 8.37 & 18.88 & 9.10 \\
\hline Prevalence of iron deficiency (\%) & 56.25 & 49.64 & 59.24 & 49.30 & 55.50 & 49.74 \\
\hline Zinc consumption (mg/day/AE) & 19.54 & 7.91 & 20.38 & 8.75 & 19.33 & 7.68 \\
\hline Prevalence of zinc deficiency (\%) & 30.99 & 46.28 & 29.94 & 45.94 & 31.26 & 46.39 \\
\hline Dietary diversity score & 8.77 & 1.40 & 9.17 & 1.24 & 8.67 & 1.42 \\
\hline$N$ (Number of observations) & 784 & & 157 & & 627 & \\
\hline
\end{tabular}

Notes: Values are means; SD, standard deviation; SM, supermarket ; TC, traditional channel; Kcal, Kilo calories; AE, adult equivalent; RE, retinol equivalent; $\mathrm{mg}$, milligrams; thresholds of deficiency is $2400 \mathrm{Kcal}$ for calories, $625 \mu \mathrm{g}$ RE for vitamin A, $18.3 \mathrm{mg}$ for iron, and $15 \mathrm{mg}$ for zinc. The differences in the indicators between the groups are not statistically significant.

\subsubsection{Empirical Results}

\section{Supermarket contracting and household income}

Table 3.4 presents the model results from household income specification. Controlling for other factors, Supplying supermarket has increased farm household income by Ksh 222,000 a $66 \%$ increase above the mean income of TC farmers. This is plausible, given the accruing benefits from supplying supermarkets. The channel offers stable and better prices to farmers compared to the traditional channel where prices are volatile across seasons. Hence, with assured market and stable prices, farmers are able to coordinate production and marketing activities thus possibly realize higher farm profits than TC farmers. Supermarket channel also has stringent quality and volumetric requirements that involve substantial farm investments in production technologies including farm inputs and irrigation equipment to facilitate yearround production and post-harvest handling equipment. Income growth facilitates such investments, leading to greater output and better quality produce thus minimizing product rejection by supermarkets. 
Table 3. 4 Supermarket contracting and household income

\begin{tabular}{|c|c|c|}
\hline \multirow[b]{2}{*}{ Variables } & \multirow{2}{*}{$\begin{array}{c}\text { Model (1) } \\
\text { Total income (RE model) }\end{array}$} & \multirow{2}{*}{$\begin{array}{c}\text { Model (2) } \\
\text { Total income (FE model) }\end{array}$} \\
\hline & & \\
\hline SM participation (dummy) ${ }^{\mathrm{a}}$ & $330.02^{* * *}(95.88)$ & $222.17^{* *}(112.48)$ \\
\hline 2012 (dummy) & $373.60^{* *}(155.69)$ & $268.51^{*}(151.03)$ \\
\hline 2015 (dummy) $^{\mathrm{b}}$ & $604.55^{* * *}(230.19)$ & $406.33^{*}(226.46)$ \\
\hline Age of household head (years) & $-0.88(1.91)$ & $3.15(3.09)$ \\
\hline Male household head (dummy) & $83.80^{*}(48.65)$ & $-7.65(54.63)$ \\
\hline Education level of farmer (years) & $23.21^{* * *}(7.16)$ & $24.82^{* *}(11.90)$ \\
\hline Off-farm income (dummy) & $128.27^{* * *}(31.97)$ & $82.11(49.90)$ \\
\hline Farm size (acres) & $52.02^{* * *}(17.30)$ & $2.23(24.00)$ \\
\hline Household size (AE) & $114.09(96.79)$ & $48.30(89.53)$ \\
\hline Kikuyu (dummy) $^{\mathrm{c}}$ & $-2.78(58.18)$ & - \\
\hline Githunguri (dummy) ${ }^{\mathrm{c}}$ & $1.87(60.29)$ & - \\
\hline Westlands (dummy) $^{\mathrm{c}}$ & $79.77(145.62)$ & - \\
\hline Constant & $-702.59^{*}(414.25)$ & $-416.44(343.11)$ \\
\hline Number of observations & 1186 & 1186 \\
\hline R-squared & & 0.07 \\
\hline Hausman test (chi-square statistic) & $20.65^{* *}$ & \\
\hline $\begin{array}{l}\text { Notes: The dependent variable is total } 1 \\
\text { errors in parentheses; SM, supermarket } \\
\text { the } 5 \% \text {, and } 1 \% \text { level, respectively ; }{ }^{a} \mathrm{R} \\
\text { region is Lari/Limuru }\end{array}$ & $\begin{array}{l}\text { ne, values deflated for compari } \\
\text { effects; FE, Fixed effects; AE, } \\
\text { is traditional channel farmers. }\end{array}$ & $\begin{array}{l}\text { ross years; Robust standard } \\
\text { quivalent; }{ }^{* * * * * *} \text { Significant a } \\
\text { nce year is } 2008 .{ }^{c} \text { Reference }\end{array}$ \\
\hline
\end{tabular}

The income effect is comparable to those of previous studies. Rao et al (2011) estimated that supplying supermarkets increased household income by $48 \%$ whereas Chege et al (2015) estimated an increase by over $60 \%$. Supplying supermarkets is also associated with reduced poverty rates (Rao et al., 2011). In a broader context, the magnitude of the effect is comparable to those from other studies that look at effects of smallholder participation in other high-value channels in developing countries (Maertens et al., 2012; Van den Broeck et al., 2016). The results suggest that smallholder participation in high-value channels increase household income substantially.

\section{Supermarket contracting and household diets}

We examine examines the association between supermarket contracting and household dietary outcomes as well as dietary diversity. Table 3.5 provides a summary of the model results but detailed results are in Tables A3.1, A3.2, and A3.3 in the appendix to chapter 3.

Supplying supermarkets is associated with positive and significant changes in consumption of calorie and zinc as well as improvement in household dietary diversity. SM farmers have a 
$265 \mathrm{Kcal}$ per AE and day higher calorie consumption - a 8\% increase compared to the average consumption by TC farmers, consume $9 \%$ more zinc, and increase their dietary diversity by $2 \%$. Dietary diversity is highly correlated with calorie consumption (Leroy et al., 2015). We do not find significant effects on vitamin A and iron consumption.

The treatment coefficient remains positive and statistically significant when only 9 groups are included. The treatment effect on dietary diversity is relatively small, possibly because the average HDDS for the farm households is already high. Using the estimated dietary effects for simple simulations suggests that wider participation of farmers in supermarket channels could help to reduce the prevalence of undernourishment by $8 \%$ and zinc deficiency by $12 \%$. Overall, results suggest that supermarkets could potentially improve household dietary diversity, consumption of calorie, and micronutrients.

Table 3. 5 Supermarket contracting and household diets

\begin{tabular}{|c|c|c|c|c|c|c|c|c|}
\hline \multirow{2}{*}{ Analysis } & \multicolumn{2}{|c|}{ Calorie(kcal/day/AE) } & \multicolumn{2}{|c|}{ HDDS 1} & \multicolumn{2}{|c|}{ HDDS 2} & \multicolumn{2}{|c|}{ Zinc(mg/day/AE) } \\
\hline & $\mathbf{R E}$ & OLS & $\mathbf{R E}$ & OLS & RE & OLS & RE & OLS \\
\hline Being in SM & $264.67^{* *}$ & $272.51^{* *}$ & $0.18^{*}$ & $0.24^{* *}$ & $0.24^{* * *}$ & $0.28^{* * *}$ & $1.84^{* *}$ & $2.14^{* *}$ \\
\hline channel & $(113.07)$ & $(115.11)$ & $(0.10)$ & $(0.10)$ & $(0.10)$ & $(0.10)$ & $(0.80)$ & $(0.79)$ \\
\hline
\end{tabular}

Values are coefficients of treatment variable with robust standard errors in parentheses, clustered at household level; Kcal, kilocalories; AE, adult equivalent; HDDS, household dietary diversity score computed from 12 food groups; mg, milligram; RE, random effects; OLS, Ordinary least squares regression; SM: supermarket; ${ }^{*},{ }^{* * * * *}$, Significant at the $5 \%$, and $1 \%$ level, respectively; dependent variables are calorie and zinc intake, HDDS 1 and HDDS 2 computed using 12 and 9 food groups, respectively. Full model estimates are in appendix to chapter 3.

These findings show a positive and significant association between supplying supermarkets and household income. Cash income facilitates economic access to adequate, safe and quality foods particularly in situations of well-functioning food markets (Jones et al., 2014). However, we do not analyze income pathway here. It should be noted that the estimates are only measures of food availability at household level and not household food security. Some studies suggest that supermarkets increase availability and accessibility of cheap, energydense but less nutritious, resulting in micronutrients malnutrition and obesity (Popkin, 2014; Kimenju et al., 2015). However, considering the study area and the estimated prevalence of undernourishment and micronutrient deficiencies, there is no reason to believe that the treatment effects result in over-nutrition particularly in the short-term. 


\section{Robustness check}

For HDDS estimation, it could be argued that the result is driven by how HDDS is measured. Hence, as a robustness check, additional dietary diversity score is computed (HDDS2) that only includes 9 food groups in the HDDS. The excluded food groups are; sweets and sugars, fats and oils, and condiments, spices and beverages. These food groups comprise energy dense but nutrient poor foods. HDDS 2 now captures the dietary quality component of access to food (Leroy et al, 2015). The treatment effects remain significant as shown in Table 3.5.

\subsection{Conclusion}

This study examines the effects of supermarket contracting farm household income and diets. Panel regression results suggest that supermarket contracting has positive and significant effects on income, and is associated with improved dietary diversity as wells as consumption of calories and micronutrients. Specifically, the results confirm that supplying supermarkets has increased farm household income by $66 \%$, and is associated with increased consumption of calorie by $8 \%$ and zinc by $9 \%$, and improvement in household dietary diversity. We do not find significant treatment effects on vitamin A and iron consumption. Using these results for simple simulations suggests that wider participation of smallholders in supermarket channels could significantly reduce the prevalence of undernourishment and the prevalence of zinc deficiency.

The findings should be interpreted with caution since supplying supermarkets and the potential spillover effects to traditional channel farmers are not analyzed. The effects could also be heterogeneous depending of context and nature of agricultural produce as seen in contract farming literature (Bellemare, 2012; Narayanan, 2014). Previous studies have highlighted high drop-out rates of smallholder farmers from supermarket channels due to stringent consistency, volumetric and quality requirements, and contract design in general. The challenges are also exacerbated by market imperfections that pervade the agricultural sector in developing countries, leading to high transaction costs even for farmers that market individually. Andersson et al (2015) find that income gains from supplying supermarkets erode when smallholder farmers drop out of the channel. This means that the improvements in diets could also diminish once the farmers exit the high-value channels. Overcoming the challenges and barriers to entry into these channels is crucial. 
From a rural development perspective, policies that widen smallholder access to markets are important. Policy initiatives that improve rural road infrastructure could facilitate access to markets, reduce transportation cost and time, and improve produce quality thereby reducing product rejection rates witnessed in supermarket channel (Andersson et al., 2015). Facilitating efficient operations of farmer groups could also be beneficial in reducing the costs. This could be through public-private sector partnerships that also improve relations between farmers and supermarkets or other buyers. This facilitates greater transparency on important contract issues e.g. grading mechanisms for fairness in pricing thereby ensuring sustainability of smallholder participation in high-value chains.

Supermarket growth in sub-Saharan Africa and Kenya in particular, could have significant welfare effects on rural farm households given the rapid urbanization, rising urban middle class, rising supermarket share of domestic retailing, supermarket expansion to other smaller cities, and their contracts with smallholder farmers for supplies of fresh horticultural produce. The spillover effects such as off-farm labor employment could significantly contribute to growth of the rural economy, household incomes, and diets. Overall, the study findings suggest that supplying supermarkets could significantly benefit rural smallholder farmers through increased incomes and improved household diets. This contributes to reduction of poverty and the burden of undernourishment and micronutrients malnutrition that is widespread in developing countries and among rural households in particular. 


\section{Appendix to Chapter 3}

Table A3. 1 Supermarket contracting and HDDS 2 -Robustness check

\begin{tabular}{|c|c|c|}
\hline \multirow[b]{2}{*}{ Variables } & \multicolumn{2}{|c|}{ HDDS 2} \\
\hline & RE & OLS \\
\hline \multirow[t]{2}{*}{ SM participation (dummy) ${ }^{\mathrm{a}}$} & $0.24^{* * *}$ & $0.28^{* * *}$ \\
\hline & $(0.08)$ & $(0.08)$ \\
\hline \multirow[t]{2}{*}{ Year 2015 (dummy) $^{b}$} & $-0.97^{* * *}$ & $-0.99^{* * *}$ \\
\hline & $(0.09)$ & $(0.10)$ \\
\hline \multirow[t]{2}{*}{ Male household head (dummy) } & 0.02 & -0.02 \\
\hline & $(0.12)$ & $(0.12)$ \\
\hline \multirow[t]{2}{*}{ Education of household head (years) } & $0.05^{* * *}$ & $0.05^{* * *}$ \\
\hline & $(0.01)$ & $(0.01)$ \\
\hline \multirow[t]{2}{*}{ Off-farm income (1000 Ksh) } & $-0.14^{*}$ & -0.12 \\
\hline & $(0.07)$ & $(0.07)$ \\
\hline \multirow[t]{2}{*}{ Farm land owned (acres) } & $0.03^{* * *}$ & $0.03^{* * *}$ \\
\hline & $(0.01)$ & $(0.01)$ \\
\hline \multirow[t]{2}{*}{ Household size (AE) } & $-0.12^{*}$ & $-0.13^{* *}$ \\
\hline & $(0.07)$ & $(0.07)$ \\
\hline \multirow[t]{2}{*}{ Kikuyu region (dummy) ${ }^{c}$} & 0.09 & 0.10 \\
\hline & $(0.08)$ & $(0.07)$ \\
\hline \multirow[t]{2}{*}{ Githunguri region (dummy) $^{\mathrm{c}}$} & -0.20 & $-0.21^{*}$ \\
\hline & $(0.13)$ & $(0.12)$ \\
\hline \multirow[t]{2}{*}{ Westlands region (dummy) $^{\mathrm{c}}$} & 0.27 & 0.24 \\
\hline & $(0.19)$ & $(0.17)$ \\
\hline \multirow[t]{2}{*}{ Constant } & $9.30^{* * *}$ & $9.39^{* * *}$ \\
\hline & $(0.34)$ & $(0.35)$ \\
\hline Wald chi2 (10) & $312.11^{* * *}$ & - \\
\hline $\mathrm{F}(10,773)$ & & $25.95^{* * *}$ \\
\hline R-squared & & 0.24 \\
\hline $\begin{array}{l}\text { Notes: Observations }=784 ; \text { Robust standar } \\
\text { OLS, ordinary least squares, AE, Adult ec } \\
\text { respectively; }{ }^{\text {a }} \text { Reference group is tradition } \\
\text { region is Lari/Limuru }\end{array}$ & $\begin{array}{l}\text { heses; SM, } \\
\text { Significant } \\
\text { rs. }{ }^{b} \text { Referer }\end{array}$ & $\begin{array}{l}\text { Random } \\
\text { and } 1 \% \text { lev } \\
{ }^{\mathrm{c}} \text { Refer }\end{array}$ \\
\hline
\end{tabular}


Table A3. 2 Supermarket contracting and dietary outcomes

\begin{tabular}{|c|c|c|c|c|c|c|c|c|c|c|}
\hline \multirow[b]{2}{*}{ Variables } & \multicolumn{2}{|c|}{ Calorie (Kcal/day/AE) } & \multicolumn{2}{|c|}{ HDDS 1} & \multicolumn{2}{|c|}{ Zinc (mg/day/AE) } & \multicolumn{2}{|c|}{ Iron (mg/day/AE) } & \multicolumn{2}{|c|}{ Vitamin A (Ug/day/AE) } \\
\hline & RE & OLS & RE & OLS & $\mathbf{R E}$ & OLS & $\mathbf{R E}$ & OLS & $\mathbf{R E}$ & OLS \\
\hline \multirow[t]{2}{*}{ SM participation (dummy) ${ }^{\mathrm{a}}$} & $264.67^{* *}$ & $272.51^{* *}$ & $0.18^{*}$ & $0.24^{* *}$ & $1.84^{* *}$ & $2.14^{* * *}$ & 0.50 & 0.55 & -22.95 & -12.72 \\
\hline & $(113.07)$ & $(115.11)$ & $(0.10)$ & $(0.10)$ & $(0.80)$ & $(0.79)$ & $(0.85)$ & $(0.87)$ & $(83.26)$ & $(80.00)$ \\
\hline \multirow[t]{2}{*}{ Year 2015 (dummy) ${ }^{b}$} & $-312.91^{* *}$ & $-328.99^{* *}$ & $-1.75^{* * *}$ & $-1.78^{* * *}$ & $-6.71^{* * *}$ & $-7.07^{* * *}$ & 1.59 & 0.80 & $-200.52^{* *}$ & $-240.57^{* *}$ \\
\hline & $(123.43)$ & $(127.55)$ & $(0.10)$ & $(0.11)$ & $(0.79)$ & $(0.82)$ & $(0.97)$ & $(0.95)$ & $(94.08)$ & $(96.93)$ \\
\hline \multirow[t]{2}{*}{ Male household head (dummy) } & -138.55 & -138.92 & 0.05 & 0.03 & $-4.49^{* * *}$ & $-4.55^{* * *}$ & $1.69^{*}$ & $1.74^{*}$ & $-225.46^{* *}$ & $-228.85^{* *}$ \\
\hline & $(133.46)$ & $(133.74)$ & $(0.13)$ & $(0.13)$ & $(1.14)$ & $(1.07)$ & $(0.93)$ & $(0.94)$ & $(112.61)$ & $(115.10)$ \\
\hline \multirow[t]{2}{*}{ Education of household head (years) } & -13.37 & -13.44 & $0.06^{* * *}$ & $0.06^{* * *}$ & 0.07 & 0.08 & 0.07 & 0.08 & $14.71^{*}$ & $15.57^{*}$ \\
\hline & (12.34) & $(12.11)$ & $(0.01)$ & $(0.01)$ & $(0.09)$ & $(0.08)$ & $(0.09)$ & $(0.08)$ & $(8.77)$ & $(8.21)$ \\
\hline \multirow[t]{2}{*}{ Off-farm income (1000 Ksh) } & -49.44 & -50.03 & $-0.19^{* *}$ & $-0.16^{*}$ & -0.29 & -0.47 & -0.27 & -0.19 & -47.71 & -58.02 \\
\hline & (91.06) & $(91.88)$ & $(0.08)$ & $(0.09)$ & $(0.57)$ & $(0.58)$ & $(0.75)$ & $(0.72)$ & $(73.91)$ & $(73.61)$ \\
\hline \multirow[t]{2}{*}{ Farm land owned (acres) } & $50.86^{* *}$ & $52.12^{* * *}$ & $0.05^{* * *}$ & $0.05^{* * *}$ & $0.21^{*}$ & $0.23^{*}$ & $0.25^{*}$ & $0.25^{*}$ & $33.30^{* *}$ & $33.02^{* *}$ \\
\hline & $(20.00)$ & $(20.15)$ & $(0.01)$ & $(0.01)$ & $(0.13)$ & $(0.13)$ & $(0.14)$ & $(0.13)$ & (13.63) & $(13.60)$ \\
\hline \multirow[t]{2}{*}{ Household size (AE) } & $-459.66^{* * *}$ & $-473.38^{* * *}$ & -0.09 & -0.12 & $-3.39^{* * *}$ & $-3.79^{* * *}$ & $-2.34^{* * *}$ & $-3.10^{* * *}$ & $-272.48^{* * *}$ & $-308.10^{* * *}$ \\
\hline & $(80.95)$ & $(83.22)$ & $(0.07)$ & $(0.07)$ & $(0.54)$ & $(0.56)$ & $(0.61)$ & $(0.58)$ & $(54.38)$ & $(54.80)$ \\
\hline \multirow[t]{2}{*}{ Kikuyu region (dummy) ${ }^{\mathrm{c}}$} & -144.01 & -141.77 & 0.09 & 0.10 & -0.53 & -0.46 & 0.30 & 0.38 & $175.31^{* *}$ & $180.04^{* *}$ \\
\hline & $(92.03)$ & $(88.41)$ & $(0.09)$ & $(0.08)$ & $(0.63)$ & $(0.58)$ & $(0.75)$ & $(0.67)$ & $(79.20)$ & $(75.16)$ \\
\hline \multirow[t]{2}{*}{ Githunguri region (dummy) ${ }^{\mathrm{c}}$} & -94.01 & -96.47 & -0.11 & -0.12 & -1.02 & -0.98 & 0.87 & 0.79 & 0.64 & 8.01 \\
\hline & $(161.05)$ & $(147.17)$ & $(0.16)$ & $(0.15)$ & $(1.06)$ & $(0.96)$ & $(1.27)$ & $(1.25)$ & $(116.66)$ & $(108.31)$ \\
\hline \multirow[t]{2}{*}{ Westlands region (dummy) $^{\mathrm{c}}$} & $-691.04^{* * *}$ & $-693.76^{* * *}$ & 0.36 & 0.31 & $-4.24^{* * *}$ & $-4.32^{* * *}$ & $-3.88^{* * *}$ & $-3.81^{* *}$ & 19.71 & 12.07 \\
\hline & $(211.11)$ & $(203.58)$ & $(0.24)$ & $(0.21)$ & $(1.37)$ & $(1.22)$ & $(1.40)$ & $(1.62)$ & (139.04) & (143.16) \\
\hline \multirow[t]{2}{*}{ Constant } & $5225.74^{* * *}$ & $5289.41^{* * *}$ & $9.22^{* * *}$ & $12.83^{* * *}$ & $32.50^{* * *}$ & $47.59^{* * *}$ & $19.80^{* * *}$ & $19.83^{* * *}$ & $2389.01^{* * *}$ & $2554.32^{* * *}$ \\
\hline & $(451.19)$ & $(477.48)$ & $(0.22)$ & $(0.40)$ & $(1.77)$ & $(3.11)$ & $(1.74)$ & $(3.34)$ & $(340.50)$ & $(353.86)$ \\
\hline Wald chi2 (10) & $68.29^{* * *}$ & & $709.84^{* * *}$ & - & $122.41^{* * *}$ & & $100.37^{* * *}$ & & $48.02^{* * *}$ & \\
\hline$F(10,773)$ & & $6.32^{* * *}$ & & $57.39^{* * *}$ & & $12.58^{* * *}$ & & $10.21^{* * *}$ & & $5.49^{* * *}$ \\
\hline R-squared & & 0.08 & & 0.41 & & 0.16 & & 0.10 & & 0.05 \\
\hline
\end{tabular}

Notes: Observations=784; Robust standard errors in parentheses; SM, supermarket; RE, Random effects; OLS, ordinary least squares, AE, Adult equivalent.

${ }^{*},{ }^{* *},{ }^{* * *}$ Significant at the $10 \%, 5 \%$, and $1 \%$ level, respectively; ${ }^{\mathrm{a}}$ Reference group is traditional channel farmers. ${ }^{\mathrm{b}}$ Reference year is $2012 .{ }^{\mathrm{c}}$ Reference region is Lari/Limuru. 
Table A3. 3 Fixed effects models for dietary outcomes

\begin{tabular}{|c|c|c|c|c|c|c|}
\hline VARIABLES & Calorie(kcal/day/AE) & HDDS 1 & HDDS 2 & Zinc(mg/day/AE) & Iron (mg/day/AE) & Vitamin A (Ug/day/AE) \\
\hline SM participation (dummy) ${ }^{\mathrm{a}}$ & $\begin{array}{c}72.30 \\
(185.30)\end{array}$ & $\begin{array}{l}-0.14 \\
(0.17)\end{array}$ & $\begin{array}{c}0.04 \\
(0.13)\end{array}$ & $\begin{array}{c}0.17 \\
(1.31)\end{array}$ & $\begin{array}{l}-0.48 \\
(1.24)\end{array}$ & $\begin{array}{l}-153.00 \\
(182.97)\end{array}$ \\
\hline Year 2015 (dummy) $^{\mathrm{b}}$ & $\begin{array}{l}-160.57 \\
(174.33)\end{array}$ & $\begin{array}{c}-1.63 * * * \\
(0.14)\end{array}$ & $\begin{array}{c}-0.88 * * * \\
(0.12)\end{array}$ & $\begin{array}{c}-5.22 * * * \\
(1.10)\end{array}$ & $\begin{array}{c}4.11 * * * \\
(1.45)\end{array}$ & $\begin{array}{c}27.33 \\
(128.56)\end{array}$ \\
\hline Male household head (dummy) & $\begin{array}{l}-103.19 \\
(358.84)\end{array}$ & $\begin{array}{c}0.42 \\
(0.27)\end{array}$ & $\begin{array}{c}0.49 * * \\
(0.21)\end{array}$ & $\begin{array}{l}-2.42 \\
(2.50)\end{array}$ & $\begin{array}{c}2.85 \\
(2.45)\end{array}$ & $\begin{array}{c}123.96 \\
(166.99)\end{array}$ \\
\hline Education level of farmer (years) & - & - & - & - & - & - \\
\hline Off-farm income (dummy) & $\begin{array}{c}-53.28 \\
(128.81)\end{array}$ & $\begin{array}{c}-0.29 * * \\
(0.12)\end{array}$ & $\begin{array}{c}-0.22 * * \\
(0.10)\end{array}$ & $\begin{array}{c}0.01 \\
(0.76)\end{array}$ & $\begin{array}{l}-0.45 \\
(1.01)\end{array}$ & $\begin{array}{c}-29.67 \\
(101.45)\end{array}$ \\
\hline Farm size (acres) & $\begin{array}{c}-2.53 \\
(76.05)\end{array}$ & $\begin{array}{c}0.01 \\
(0.05)\end{array}$ & $\begin{array}{c}0.01 \\
(0.04)\end{array}$ & $\begin{array}{l}-0.13 \\
(0.40)\end{array}$ & $\begin{array}{l}0.001 \\
(0.45)\end{array}$ & $\begin{array}{c}-1.97 \\
(51.19)\end{array}$ \\
\hline Household size (AE) & $\begin{array}{c}-318.79 * * \\
(128.8)\end{array}$ & $\begin{array}{c}0.01 \\
(0.11)\end{array}$ & $\begin{array}{l}-0.07 \\
(0.09)\end{array}$ & $\begin{array}{c}-1.82 * * \\
(0.79)\end{array}$ & $\begin{array}{c}0.10 \\
(1.04)\end{array}$ & $\begin{array}{l}-69.77 \\
(88.79)\end{array}$ \\
\hline Kikuyu region (dummy) ${ }^{\mathrm{c}}$ & - & - & - & - & - & - \\
\hline Githunguri region (dummy) ${ }^{c}$ & - & - & - & - & - & - \\
\hline Westlands region (dummy) ${ }^{\mathrm{c}}$ & - & - & - & - & - & - \\
\hline Constant & $\begin{array}{c}4462.86^{* * *} \\
(759.30)\end{array}$ & $\begin{array}{c}12.69 * * * \\
(0.64)\end{array}$ & $\begin{array}{c}9.20 * * * \\
(0.52)\end{array}$ & $\begin{array}{c}38.38 * * * \\
(5.02)\end{array}$ & $\begin{array}{c}6.25 \\
(6.17)\end{array}$ & $\begin{array}{c}1430.76^{* * *} \\
(529.10)\end{array}$ \\
\hline Number of observations & 784 & 784 & 784 & 784 & 784 & 784 \\
\hline R-squared & 0.04 & 0.63 & 0.39 & 0.13 & 0.13 & 0.01 \\
\hline Hausman (chi-square statistic) & 4.40 & 9.47 & 6.45 & 4.37 & 2.33 & 4.75 \\
\hline
\end{tabular}




\section{General Conclusion}

We set out to first analyze smallholder farmers' preferences for contracts and design attributes before examining the effects of their participation in supermarket channels on household income and diets. The two objectives were achieved as elucidated in the two preceding chapters of this dissertation. Contract configuration, among other factors, is an integral determinant of smallholder participation in marketing contracts and particularly supermarket contracts if it balances marketing risks between the parties. Smallholder participation in such high-value markets has positive and significant effects on farm households' welfare in terms of income and nutrition. Hence, depending on the context and the nature of the agricultural products, contract farming remains a promising pathway towards linking smallholder farmers to markets and improving their welfare as seen in the example of supermarket contracts.

\subsection{Main Findings}

From the panel data, high drop-out rates from supermarket channels are observed between 2008 and 2015. Our study was motivated by the need to understand why this is the case, which partially pointed to issues of contract design among other constraints. We also analyzed the effects of supplying supermarkets on household income and diets, the latter having received little attention in the existing literature on supermarkets. The key findings are summarized as follows.

The findings in chapter 2 of this dissertation stem from a choice experiment to analyze farmers' preferences and preference heterogeneity for supermarket contracts in Kenya. Various specifications of mixed logit models were employed and results show that farmers without previous contract experience have more negative attitudes towards contracts in general. Some socioeconomic characteristics of the farmers influence preferences for contracts and design attributes such as gender and age, income, and education. Several other studies have documented such socioeconomic factors to also be significant drivers of farm production, productivity, and marketing capacity.

The contractual features associated with high transaction costs and risks impede farmers' willingness to contract especially among the locationally disadvantaged from remote areas with poor road infrastructure. Such farmers are more inclined to group marketing to overcome 
the marketing challenges. This is closely related to the most problematic contract attribute, payment mode. While delayed payment is very common in such contracts, farmers have more negative attitude towards contracts with delayed payments based on quantities that supermarkets finally sell to customers because all the marketing risks are then transferred to farmers. Farmers' willingness to accept output prices triple when contract clauses involve payments for unverifiable quantities sold to customers.

Chapter 3 provides the main findings from panel data analysis of the effects of supermarket contracting on household income and diets using fixed effects and random effects estimators. We find that supermarket contracting is associated with positive and significant increase in household income and diets. Specifically, supplying supermarkets has increased farm household income by $66 \%$ and improves dietary diversity, consumption of calories and zinc. Increased incomes improve farm households' economic access to diverse and nutritious foods that improve dietary diversity, calories, and micronutrient consumption especially if food markets are well functioning.

These findings illuminate the key issues on contract design and farmers' preferences, and subsequent welfare implications of supermarket contracting. This is important when examining the pathways to link smallholder farmers to high-value markets through contracts, a balance between viability and competing interests of farmers and buyers.

\subsection{Policy Implications}

From a development perspective, our empirical results have some important policy implications, given the significant role that small farm sector plays in enhancing economic growth in many developing countries. Contract configuration influences farmers' preferences for contracts, particularly supermarket contracts. Supermarket contracts that balance risks between parties may facilitate smallholder access to supermarket channels, which could have positive and significant effects on farm households' welfare. For example, supermarket contracts potentially increase investment in productive assets that facilitate increased crop production. Depending on the types of crops produced, this can increase food production thus availability of food within farm households. Growth in farm profits also increase household income that could significantly reduce rural poverty given that majority of the rural households are smallholder farmers. Overall, improved financial status of contracted farm households increases their purchasing power thereby facilitating economic access to diverse, 
safe, and nutritious foods. This could significantly ameliorate the high prevalence of undernutrition and micronutrients malnutrition as shown in the analysis.

Linking smallholders to high-value markets would therefore be beneficial to the development and growth of the agricultural sector in developing countries. Such developments also lead to positive spillovers such as farm and off-farm employment of laborers within the emerging value chains and reduced rural-urban migration. Given the findings, the onus is on the Government agencies and other stakeholders in the value chains to strike a balance in the interventions to increase smallholder participation in high-value channels such as supermarkets. Specifically, findings on preferences for contracts highlight the need for regulatory frameworks to govern contracts by balancing risks, ensuring accountability and transparency in quality grading of farm produce and price formation mechanisms. This could create opportunities for gainful smallholder farming and market access as well as stability of such high-value chains.

A few constraints to smallholder participation in supermarket contracts are mentioned in this dissertation and are captured by the various contract design attributes discussed. Further, certain socioeconomic and demographic characteristics emerge as drivers of supermarket contracting. Leveraging gains from supermarket contracting and its modalities is key to enhancing smallholder inclusion in high-value markets. In particular, group marketing comes out as important in ensuring consistent supplies to supermarkets from smallholders who otherwise would not aggregate required volumes.

Performance of farmer organizations in most developing countries is ineffective as observed in many studies. Interventions that strengthen operations of farmer organizations or interest groups involved in collective marketing are beneficial as they are conduits for technology transfer and market information exchanges thus reducing transaction and transportation costs incurred by smallholders. Vegetable farmers in the study areas also mentioned unreliable and high costs of transportation, long distances to markets and poor roads as marketing impediments during the focus group discussions. Hence, infrastructural upgrades are beneficial in reducing transportation time and costs while preserving quality of produce in the process. This could reduce the high product rejection rates currently observed in the supermarket channel. 
Scaling up smallholder participation in high-value channels characterized by contracts is not a panacea for smallholder marginalization from high-value markets, rural poverty, undernourishment and micronutrient malnutrition. Concerted multi-pronged efforts are necessary to make smallholder inclusion in such channels consistent and profitable. This would require not only output market interventions but also input markets to facilitate smallholder farmers' access to appropriate technologies for production (including genuine quality seeds and crop chemicals) and regulatory frameworks for sustainable production, access and use of arable land.

Supermarket contracting has had positive significant effects on farm households' welfare up till now. However, some studies also show that economic gains from supplying supermarkets erode when farmers drop-out. This means that improvement in nutritional status of households could also deteriorate when the farmers revert to traditional channels. With the dynamic food-marketing environment, an optimistic view would be that the positive effects of supermarket contracting persist over time. In this regard, more follow-up studies with larger sample of farmers are required to analyze longer-term effects of supplying supermarkets. This remains an active area of research and the conclusions in the event of such undertakings are wide open.

\subsection{Study Limitations and Future Research}

We analyzed farmers' preferences for supermarket contracts and the effects of supermarket contracting on farm households' income and nutrition. However, agricultural markets in most developing countries are imperfect and global agri-food systems are rapidly transforming with significant implications for both domestic and agricultural export markets. This dynamism requires continuous assessment of the evolving contracts and implications on smallholder welfare. We used a few selected attributes for the choice experiment that may not conclusively surmise the dynamic contractual environment but nonetheless capture key contract attributes that largely influence farmers' willingness to contract and tradeoffs between them. Future studies could incorporate other additional attributes that possibly influence farmers' preferences for contracts. 
We acknowledge the following computational challenges of estimating dietary outcomes in our study particularly in estimating the daily intakes of energy (calories) and micronutrients. In the estimations, we use random effects estimator therefore possible endogeneity issues such as sample selection bias still remain. This is occasioned by limited within group variations given only two rounds of data are available. Besides, we do not believe there are any time variant unobserved characteristics of the farmers that would affect our result in such a short time period. Nonetheless, more rounds of data would yield robust estimates.

It should be noted that the daily consumption estimates and dietary diversity score are only measures of food availability and not actual quantities eaten. Hence, not perfect measures of household food security or nutrition for the following reasons. First, food wastes, gifts and usage for other purposes are not fully accounted for. Second, we did not capture the composition of the diets and therefore assumed bioavailability thresholds mentioned. Lastly, 7-day recall data used do not account for intra-household food distribution that affects nutrition status of household members. There may also be seasonal variations in consumption that could not be accounted for. Such could be made possible with more frequent surveys. Nonetheless, these drawbacks affect all the groups of farmers in a similar way so that there should be no systematic bias in estimates.

Household dietary diversity score has been criticized as an inadequate measure of dietary quality. In our study, we excluded certain food groups as also done in similar studies in order to capture the quality component of access to food. Future studies could explore other measures of dietary quality such as women or individual dietary diversity score that focus on adequacy of micronutrients in the diet. Twenty-four hours recall data collected at individual level would also be more precise to assess further details of dietary quality.

Like many other studies, our study focused on a limited geographical coverage that also limits wider interpretation of results. Future studies could use nationally representative samples to analyze broader impacts of contract farming in diverse contexts. With larger samples, it is easier to analyze heterogeneous effects of supermarket contracting. It could also be interesting to analyze the longer-term spillover effects of supermarket contracting to other farm enterprises, especially for supermarket channel drop-outs and farmers that are unable to join the channel but potentially benefit from technology transfer and marketing information from neighboring supermarket suppliers. 


\section{Bibliography}

Abebe, G.K., Bijman, J., Kemp, R., Ota, O., Tsegaye, A., 2013. Contract farming configuration: smallholders' preferences for contract design attributes. Food Policy 40, $14-24$.

Alene, A.D., Manyong, V.M., Omanya, G., Mignouna, H.D., Bokanga, M., Odhiambo, G., 2008. Smallholder market participation under transactions costs: Maize supply and fertilizer demand in Kenya. Food Policy 33 (4), 318-328.

Alston, J.M., Norton, G.W. and Pardey, P.G., 1995. Science under scarcity: Principles and practice for agricultural research priority setting and evaluation. Cornell University: Ithaca, NY, USA.

Andersson, C.I., Chege, C.G., Rao, E.J., Qaim, M., 2015. Following up on smallholder farmers and supermarkets in Kenya. American Journal of Agricultural Economics 97 (4), $1247-1266$.

Asfaw, A., 2008. Does Supermarket purchase affect the dietary practices of households?: Some empirical evidence from Guatemala. Development Policy Review 26 (2), 227-243.

Asfaw, S., Mithöfer, D., Waibel, H., 2009. EU Food safety standards, pesticide use and farmlevel productivity: The case of high-value crops in Kenya. Journal of Agricultural Economics 60 (3), 645-667.

Asfaw, S., Mithöfer, D., Waibel, H., 2010. What impact are EU supermarket standards having on developing countries' export of high-value horticultural products? Evidence from Kenya. Journal of International Food and Agribusiness Marketing 22 (3-4), 252-276.

Ayieko M. W., Tschirley D. L., Mathenge M.W., 2005. Fresh fruit and vegetable consumption patterns and supply chain systems in urban Kenya: Implications for policy and investment priorities. Working Paper (No.16). Tegemeo Institute of Agricultural Policy and Development.

Barrett, C.B., Back, M.E., Bellemare, M.F., Michelson, H.C., Narayanan, S., Walker, T.F., 2012. Smallholder participation in contract farming: comparative evidence from five countries. World Development. 40 (4), 715-730.

Bell, A., Jones, K., 2015. Explaining fixed effects: Random effects modeling of time-series cross-sectional and panel data. PSRM 3 (1), 133-153.

Bellemare, M.F., 2012. As you sow, so shall you reap: The welfare impacts of contract farming. World Development 40 (7), 1418-1434. 
Bellemare, M.F., Novak, L., 2016. Contract farming and food security. American Journal of Agricultural Economics. (in press).

Berdegué, J.A., Balsevich, F., Flores, L., Reardon, T., 2005. Central American supermarkets' private standards of quality and safety in procurement of fresh fruits and vegetables. Food Policy 30 (3), 254-269.

Blandon, J., Henson, S., Cranfield, J., 2009a. Small-scale farmer participation in new agrifood supply chains: Case of the supermarket supply chain for fruit and vegetables in Honduras. Journal of International Development 21 (7), 971-984.

Blandon, J., Henson, S., Islam, T., 2009b. Marketing preferences of small-scale farmers in the context of new agrifood systems: A stated choice model. Agribusiness 25 (2), 251-267.

Bognár A., 2002. Tables on weight yield of food and retention factors of food constituents for the calculation of nutrient composition of cooked foods (dishes). Karlsruhe: Federal Research Centre for Nutrition.

Cameron, A. C., Trivedi, P. K., 2005. Microeconometrics: Methods and applications. Cambridge: Cambridge University Press.

Chege, C.G., Andersson, C.I., Qaim, M., 2015. Impacts of supermarkets on farm household nutrition in Kenya. World Development 72, 394-407.

Codron, J.-M., Bouhsina, Z., Fort, F., Coudel, E., Puech, A., 2004. Supermarkets in lowincome mediterranean countries: Impacts on horticulture systems. Development Policy Review 22 (5), 587-602.

Codron, J.-M., Giraud-Héraud, E., Soler, L.-G., 2005. Minimum quality standards, premium private labels, and European meat and fresh produce retailing. Food Policy 30 (3), 270283.

Dedehouanou, S.F.A., Swinnen, J., Maertens, M., 2013. Does contracting make farmers happy? Evidence from Senegal. Review of Income and Wealth 59, S138-S160.

Eaton, C. and Shepherd, A., 2001. Contract farming: partnerships for growth (No. 145). Food and Agriculture Organization of the United Nations.

Escobal, J.A., Cavero, D., 2012. Transaction costs, institutional arrangements and inequality outcomes: Potato marketing by small producers in rural Peru. World Development 40 (2), 329-341.

FAO, 2014. The state of food and agriculture. FAO, Rome.

FAO, WHO, UNU, 2001. Human energy requirements: Report of a joint expert consultation. Rome: Food and nutrition technical report, Food and Agricultural Organization of the United Nations. 
Fischer, E., Qaim, M., 2012. Gender, agricultural commercialization, and collective action in Kenya. Food Security. 4 (3), 441-453.

Gautam, Y., Andersen, P., 2016. Rural livelihood diversification and household well-being: Insights from Humla, Nepal. Journal of Rural Studies 44, 239-249.

Gelaw, F., Speelman, S., Van Huylenbroeck, G., 2016. Farmers' marketing preferences in local coffee markets: Evidence from a choice experiment in Ethiopia. Food Policy 61, 92 102.

Giné, X., Yang, D., 2009. Insurance, credit, and technology adoption: Field experimental evidencefrom Malawi. Journal of Development Economics 89 (1), 1-11.

Gómez, M.I., Ricketts, K.D., 2013. Food value chain transformations in developing countries: Selected hypotheses on nutritional implications. Food Policy 42, 139-150.

Hausman, J. A., 1978. Specification tests in econometrics. Econometrica 46, 1251-1271.

Hazell, P., Poulton, C., Wiggins, S., Dorward, A., 2010. The future of small farms: Trajectories and policy priorities. World Development 38 (10), 1349-1361.

Hensher, D.A., Rose, J.M., Greene, W.H., 2005. Applied choice analysis: A primer. Cambridge University Press, Cambridge.

Herforth, A., Ballard, T.J., 2016. Nutrition indicators in agriculture projects: Current measurement, priorities, and gaps. Global Food Security 10, 1-10.

Hernández, R., Reardon, T., Berdegué, J., 2007. Supermarkets, wholesalers, and tomato growers in Guatemala. Agricultural Economics 36 (3), 281-290.

Hole, A., 2007. Fitting mixed logit models by using maximum simulated likelihood. Stata Journal 7 (3), 388-401.

Hole, A.R., Kolstad, J.R., 2012. Mixed logit estimation of willingness to pay distributions: A comparison of models in preference and WTP space using data from a health-related choice experiment. Empirical Economics 42 (2), 445-469.

Horton, R., Lo, S., 2013. Nutrition: A quintessential sustainable development goal. The Lancet, 382, 371-372.

IFPRI, 2016. Global nutrition report 2016. From promise to impact ending malnutrition by 2030. Washington, DC: International Food Policy Research Institute.

IZiNCG, 2004. Assessment of the risk of zinc deficiency in populations and options for its control. Food and Nutrition Bulletin 25, S91-S202. International Zinc Nutrition Consultative Group. 
Jaffee, S., Masakure, O., 2005. Strategic use of private standards to enhance international competitiveness: Vegetable exports from Kenya and elsewhere. Food Policy 30 (3), 316333.

Jenkins, R., 2004. Globalization, production, employment and poverty: Debates and evidence. Journal of International Development 16 (1), 1-12.

Jones, A.D., Shrinivas, A., Bezner-Kerr, R., 2014. Farm production diversity is associated with greater household dietary diversity in Malawi: Findings from nationally representative data. Food Policy 46, 1-12.

Kimenju, S.C., Rischke, R., Klasen, S., Qaim, M., 2015. Do supermarkets contribute to the obesity pandemic in developing countries? Public health nutrition 18 (17), 3224-3233.

KNBS, 2008. Kenya Demographic and Health Survey 2008-2009: Kenya National Bureau of Statistics.

Koppmair, S., Kassie, M., Qaim, M., 2017. Farm production, market access and dietary diversity in Malawi. Public Health Nutrition 20 (2), 325-335.

Lancaster, K.J., 1966. A new approach to consumer theory. Journal of Political Economy 74, $132-157$.

Leroy, J.L., Ruel, M., Frongillo, E.A., Harris, J., Ballard, T.J., 2015. Measuring the food access dimension of food security: A critical review and mapping of indicators. Food and Nutrition Bulletin 36 (2), 167-195.

Louviere, J.J., Flynn, T.N., Carson, R.T., 2010. Discrete choice experiments are not conjoint analysis. Journal of Choice Modelling 3 (3), 57-72.

Maertens, M., Minten, B., Swinnen, J., 2012. Modern food supply chains and development: Evidence from horticulture export sectors in Sub-Saharan Africa. Development Policy Review 30 (4), 473-497.

McFadden, D., Zarembka, P., 1974. Conditional logit analysis of qualitative choice behavior. Frontiers in Econometrics, 105-142.

Mergenthaler, M., Weinberger, K., Qaim, M., 2009. The food system transformation in developing countries: A disaggregate demand analysis for fruits and vegetables in Vietnam. Food Policy 34 (5), 426-436.

Michelson, H., Reardon, T., Perez, F., 2012. Small farmers and big retail: Trade-offs of supplying supermarkets in Nicaragua. World Development 40 (2), 342-354.

Michelson, H.C., 2013. Small farmers, NGOs, and a Walmart world: Welfare effects of supermarkets operating in Nicaragua. American Journal of Agricultural Economics 95 (3), 628-649. 
Minten, B., Randrianarison, L., Swinnen, J.F.M., 2009. Global retail chains and poor farmers: Evidence from Madagascar. World Development 37 (11), 1728-1741.

Miyata, S., Minot, N., Hu, D., 2009. Impact of contract farming on income: Linking small farmers, packers, and supermarkets in China. World Development 37 (11), 1781-1790.

Moustier, P., Tam, P.T.G., Anh, D.T., Binh, V.T., Loc, N.T.T., 2010. The role of farmer organizations in supplying supermarkets with quality food in Vietnam. Food Policy 35 (1), $69-78$.

Muriithi, B.W., Matz, J.A., 2015. Welfare effects of vegetable commercialization: Evidence from smallholder producers in Kenya. Food Policy 50, 80-91.

Muyanga, M., Jayne, T.S., 2014. Effects of rising rural population density on smallholder agriculture in Kenya. Food Policy 48, 98-113.

Narayanan, S. and Gulati, A., 2002. Globalization and the Smallholders: A Review of Issues, Approaches, and Tentative Conclusions. Unpublished, International Food Policy Research Institute, Washington DC.

Narayanan, S., 2014. Profits from participation in high value agriculture: Evidence of heterogeneous benefits in contract farming schemes in Southern India. Food Policy 44, $142-157$.

Neven, D., Odera, M.M., Reardon, T., Wang, H., 2009. Kenyan supermarkets, emerging middle-class horticultural farmers, and employment impacts on the rural poor. World Development 37 (11), 1802-1811.

Ochieng, D.O., Veettil, P.C., Qaim, M., 2017. Farmers' preferences for supermarket contracts in Kenya. Food Policy 68, 100-111.

Okello, J.J., Swinton, S.M., 2007. Compliance with international food safety standards in Kenya's green bean industry: Comparison of a small- and a large-scale farm producing for export. Review of Agricultural Economics 29 (2), 269-285.

Olwande, J., Smale, M., Mathenge, M.K., Place, F., Mithöfer, D., 2015. Agricultural marketing by smallholders in Kenya: A comparison of maize, kale and dairy. Food Policy $52,22-32$.

Otsuka, K., Nakano, Y., Takahashi, K., 2016. Contract farming in developed and developing countries. Annual Review of Resource Economics 8, 353-376.

Planet Retail, 2016. Country Report: Kenya. http://www.planetretail.net/Markets/Country/91. Accessed 8 February 2016.

Planet Retail, 2017. Country Report: Kenya. http://www.planetretail.net/Markets/Country/91. Accessed 20 February 2017. 
Popkin, B.M., 2014. Nutrition, Agriculture and the Global Food System in Low and Middle Income Countries. Food Policy 47, 91-96.

Popkin, B.M., Adair, L.S., Ng, S.W., 2012. Global nutrition transition and the pandemic of obesity in developing countries. Nutrition reviews 70 (1), 3-21.

PRB, 2017. Population Reference Bureau, Data Finder. http://www.prb.org. Accessed 19 February 2017.

Qaim, M., 2017. Globalisation of agrifood systems and sustainable nutrition. Proceedings of the Nutrition Society 76 (1), 12-21.

Rao, E.J., Qaim, M., 2011. Supermarkets, farm household income, and poverty: Insights from Kenya. World Development 39 (5), 784-796.

Rao, E.J., Qaim, M., 2013. Supermarkets and agricultural labor demand in Kenya: A gendered perspective. Food Policy 38, 165-176.

Rao, E.J.O., Brümmer, B., Qaim, M., 2012. Farmer participation in supermarket channels, production technology, and efficiency: The case of vegetables in Kenya. American Journal of Agricultural Economics 94 (4), 891-912.

Reardon, T., Timmer, C.P., 2014. Five inter-linked transformations in the Asian agrifood economy: Food security implications. Global Food Security 3 (2), 108-117.

Reardon, T., Timmer, C.P., Barrett, C.B., Berdegue, J., 2003. The rise of supermarkets in Africa, Asia, and Latin America. American Journal of Agricultural Economics 85 (5), $1140-1146$.

Reardon, T., Timmer, C.P., Minten, B., 2012. Supermarket revolution in Asia and emerging development strategies to include small farmers. Proceedings of the National Academy of Sciences of the United States of America 109 (31), 12332-12337.

Rischke, R., Kimenju, S.C, Klasen, S., Qaim, M., 2015. Supermarkets and food consumption patterns: The case of small towns in Kenya. Food Policy 52, 9-21.

RoK, 2012. National Nutrition Action Plan 2012-2017. Republic of Kenya. http://scalingupnutrition.org. Accessed 19 February 2017.

Rosch, S., Ortega, D., 2014. Looking for causes of effects: Imperfect contract enforcement in Kenya's french bean market. Paper presented at the annual meeting of the Agricultural and Applied Economics Association, July 27-29, 2014, Minneapolis, MN.

Rosenzweig, M.R., Wolpin, K.I., 1993. Credit market constraints, consumption smoothing, and the accumulation of durable production assets in low-income countries: Investments in bullocks in India. Journal of Political Economy 101 (2), 223-244. 
Saenger, C., Qaim, M., Torero, M., Viceisza, A., 2013. Contract farming and smallholder incentives to produce high quality: Experimental evidence from the Vietnamese dairy sector. Agricultural Economics 44 (3), 297-308.

Saenger, C., Torero, M., Qaim, M., 2014. Impact of third-party contract enforcement in agricultural markets - a field experiment in Vietnam. American Journal of Agricultural Economics 96, 1220-1238.

Sartorius, K., Kirsten, J., 2007. A framework to facilitate institutional arrangements for smallholder supply in developing countries: An agribusiness perspective. Food Policy 32 (5-6), 640-655.

Schipmann, C., Qaim, M., 2011. Supply chain differentiation, contract agriculture, and farmers' marketing preferences: The case of sweet pepper in Thailand. Food Policy 36 (5), $667-677$.

Sehmi, J. K., 1993. National food composition tables and the planning of satisfactory diets in Kenya. Nairobi: Kenya Government Press.

Sibhatu, K.T., Krishna, V.V., Qaim, M., 2015. Production diversity and dietary diversity in smallholder farm households. Proceedings of the National Academy of Sciences of the United States of America 112 (34), 10657-10662.

Swinnen, J., Deconinck, K., Vandemoortele, T. and Vandeplas, A., 2015. Quality standards, value chains, and international development: Economic and political theory. Cambridge University Press.

Swinnen, J.F.M., Vandeplas, A., Maertens, M., 2011. Liberalization, endogenous institutions, and growth: A Comparative analysis of agricultural reforms in Africa, Asia, and Europe. The World Bank Economic Review 24 (3), 412-445.

Townsend, Z., Buckley, J., Harada, M., Scott, M., 2013. The Choice between Fixed and Random Effects, in: Scott, M., Simonoff, J., Marx, B. (Eds.), The SAGE Handbook of Multilevel Modeling. SAGE Publications Ltd, 1 Oliver's Yard, 55 City Road, London EC1Y 1SP United Kingdom, 73-88.

Traill, W.B., 2006. The Rapid Rise of Supermarkets? Development Policy Review 24 (2), $163-174$.

Trebbin, A., 2014. Linking small farmers to modern retail through producer organizations Experiences with producer companies in India. Food Policy 45, 35-44.

Tschirley, D., Reardon, T., Dolislager, M., Snyder, J., 2015. The Rise of a Middle Class in East and Southern Africa: Implications for Food System Transformation. Journal of International Development 27, 628-646. 
Umberger, W.J., He, X., Minot, N., Toiba, H., 2015. Examining the Relationship between the Use of Supermarkets and Over-nutrition in Indonesia. American Journal of Agricultural Economics 97 (2), 510-525.

Unnevehr, L.J., 2000. Food safety issues and fresh food product exports from LDCs. Agricultural Economics 23 (3), 231-240.

Van den Broeck, G., Maertens, M., 2016. Horticultural exports and food security in developing countries. Global Food Security 10, 11-20.

Vassalos, M., Hu, W., Woods, T., Schieffer, J., Dillon, C., 2016. Risk preferences, transaction costs, and choice of marketing contracts: Evidence from a choice experiment with fresh vegetable producers. Agribusiness 32 (3), 379-396.

Veettil, P.C., Speelman, S., Frija, A., Buysse, J., van Huylenbroeck, G., 2011. Complementarity between water pricing, water rights and local water governance: A Bayesian analysis of choice behaviour of farmers in the Krishna river basin, India. Ecological Economics 70 (10), 1756-1766.

Von Braun, J., 1994. Production, employment, and income effects of commercialization of agriculture. In: J. von Braun and Kennedy, E. (Ed.), Agricultural Commercialization, Economic Development, and Nutrition. Published for the International Food Policy Research Institute: The Johns Hopkins University Press, Baltimore and London.

Wang, H.H., Wang, Y., Delgado, M.S., 2014. The transition to modern agriculture: Contract farming in developing economies. American Journal of Agricultural Economics 96 (5), $1257-1271$.

WHO, FAO., 2004. Vitamin and mineral requirements in human nutrition (2nd ed.). Geneva: World Health Organization of the United Nations.

Wiggins, S., Kirsten, J., Llambí, L., 2010. The future of small farms. World Development 38 (10), 1341-1348.

Wooldridge, J. M., 2010. Econometric analysis of cross section and panel data. (2nd ed.). Cambridge, Mass., London: MIT.

World Bank, 2007. World development report 2008: Agriculture for development. Washington DC: World Bank.

World Bank, 2016. World Development Indicators 2016. Washington, DC: World Bank. 


\title{
General Appendix
}

\section{Household Questionnaire}

HOUSEHOLD SURVEY 2015

UNIVERSITY OF GÖTTINGEN

\author{
FOLLOW UP SURVEY ON ACCESS TO HIGH-VALUE AGRICULTURAL MARKETS AND \\ IMPLICATIONS FOR RURAL DEVELOPMENT: THE CASE OF VEGETABLE PRODUCTION IN \\ CENTRAL KENYA.
}

\begin{abstract}
"We are students from Gottingen University-Germany, who are studying different aspects of agricultural development. We are currently doing a follow up survey on the study first conducted by James Rao in 2008 and continued by Christine Chege and Camilla Anderson in 2012 about vegetable production in Kiambu area. The main purpose of this study is to understand more about farmers' decisions about production and marketing of vegetables. Your participation in answering these questions is very much appreciated. Your responses will be COMPLETELY CONFIDENTIAL and will only be used for research purpose. Your responses will be added to those of 402 other households and analyzed together. If you indicate your voluntary consent by participating in this interview, may we begin?
\end{abstract}

$\left.\begin{array}{l}\text { Household No: } \\ \text { Survey Date: }(\mathrm{dd} / \mathrm{mm} / \text { yyyy })\end{array}\right)$ SURDATE

HH head Name (Full name)

Respondent's name (Full name) MEMID

Cell phone number

(Enumerator Instruction: Record the member number (MEMID) of the Respondent from the Demography table on page 29 after the survey is completed.)

\section{Identifying Variables:}

Supervisor:

Enumerator:

District:

Division:

Location:

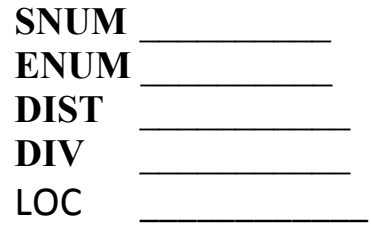

SUBLOC

VIL

Sub-Location:

Village:

Supplier to HVC? $(0=\mathrm{No} ; 1=$ Yes directly; $2=$ Indirectly $)$

Split of Household HHID:

(0 if not; HHID of original HH if Yes)

GPS Coordinats (homestead):

GPS No :

HVCSUPLR in 2008

Replacement Household:

Household moved Waypoint No :

$2=$ South)

(1=North;
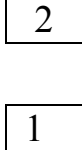

$\mathrm{EAST}=1$

ELEVATION (M.A.S.L)
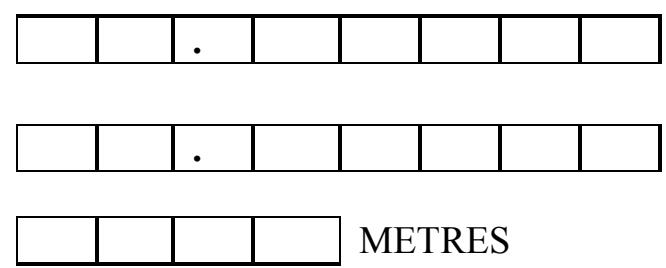

DECODE

Data entry clerk Name: 


\section{Questionnaire number (HHID)}

\subsection{SECTION 1: GENERAL FARMING INFORMATION}

1.1 In total, what is the size of the land holding (area owned) by this household?
a) Size
b) Unit
$\left(1=\right.$ acres, $2=m^{2}, 3=H a, 4=$ feet $\left.^{2}\right)$

1.2 For how long have you been farming (as an independent household)?
a) Years:
b) Months:

1.3 What was the size of the farm when you started cultivating it?

a) Size:

b) Unit: $\left(1=\right.$ acres, $2=m^{2}, 3=H a, 4=$ feet $\left.^{2}\right)$

1.4 In the current season (March-August 2015), what crops do you grow on your farm and what size of your farm is allocated to each crop grown?

\begin{tabular}{|c|c|c|c|c|c|c|c|}
\hline \multirow[b]{2}{*}{$\begin{array}{l}\text { Crop } \\
\text { code }\end{array}$} & \multirow[b]{2}{*}{ Crop name } & & \multirow{2}{*}{$\begin{array}{l}\text { Responsible } \\
\text { MEMID of } \\
\text { primarily } \\
\text { responsible } \\
\text { for this crop }\end{array}$} & \multicolumn{2}{|c|}{ Total area under crop } & \multirow{2}{*}{$\begin{array}{l}\text { Area owned } \\
\text { Area (use the } \\
\text { same unit code } \\
\text { as for total area } \\
\text { under crop) }\end{array}$} & \multirow{2}{*}{$\begin{array}{l}\text { Area leased in } \\
\text { Area (use the } \\
\text { unit code for } \\
\text { as for total } \\
\text { area under } \\
\text { crop) }\end{array}$} \\
\hline & & & & Area & $\begin{array}{l}\text { Unit } \\
(\text { Unit } \\
\text { Codes })^{a}\end{array}$ & & \\
\hline 1 & All Vegetables ${ }^{b}$ & & & & & & \\
\hline 2 & Potatoes (Irish) & & & & & & \\
\hline 3 & Sweet potatoes & & & & & & \\
\hline 4 & Maize & & & & & & \\
\hline 5 & Beans & & & & & & \\
\hline 6 & Yams & & & & & & \\
\hline 7 & Tea & & & & & & \\
\hline 8 & Coffee & & & & & & \\
\hline 9 & Bananas & & & & & & \\
\hline 10 & Fodder & & & & & & \\
\hline 11 & Other (Specify1_ & $\left.\_\right)$ & & & & & \\
\hline 12 & Other (Specify2 & ) & & & & & \\
\hline 13 & Other (Specify3 & ) & & & & & \\
\hline 14 & Other (Specify4 & ) & & & & & \\
\hline 15 & Other (Specify5 & ) & & & & & \\
\hline & Total area leased out & & & & & & \\
\hline
\end{tabular}

${ }^{a}$ UNIT CODE: $1=$ acres, $2=m^{2}, 3=H a$, , $4=$ feet $^{2}$

${ }^{b}$ Vegetables refers to all vegetables including tomatoes and onions 
1.5 Do you use irrigation on your farm? $(Y e s=1 ;$ No $=0)($ If No, Go to Q1.9)

1.6 If yes, how long have you been using irrigation? Years: Months:

1.7 For the current season (March-August 2015), what size of your total cultivated area is irrigated?
a) Size:
b) Unit:
$\left(1=\right.$ acres, $2=m^{2}, 3=H a, 4=$ feet $\left.^{2}\right)$

1.8 If you irrigate part/whole of your farm, what special irrigation equipment do you have?

\begin{tabular}{|c|c|}
\hline Irrigation equipment/tool & $1=Y E S ; 0=N O$ \\
\hline 1) Water pump & \\
\hline 2) Borehole & \\
\hline 3) Well & \\
\hline 4) Dam & \\
\hline 5) Water tank & \\
\hline 6) Drip irrigation system & \\
\hline 7) Special pipes & \\
\hline 8) Sprinkler & \\
\hline 9) Watering can & \\
\hline 10) Other (please specify) & \\
\hline
\end{tabular}

1.9 What is the value of all vegetables sold and consumed from the farm for the LAST crop year (2014/2015)? (Please make sure that sales and consumption from the FULL year is included)

\begin{tabular}{|l|l|l|l|l|l|l|l|}
\hline \multicolumn{3}{|c|}{ Rainy season } & \multicolumn{3}{c|}{ Dry season } \\
(March-May 2014 and Nov-Dec 2014) & \multicolumn{3}{|c|}{ (June-October 2014 and Jan-February 2015) } \\
\hline $\begin{array}{l}\text { Number of } \\
\text { months sold }\end{array}$ & $\begin{array}{l}\text { Value } \\
\text { sold/month } \\
\text { (Ksh) }\end{array}$ & $\begin{array}{l}\text { Number of } \\
\text { months } \\
\text { consumed }\end{array}$ & $\begin{array}{l}\text { Value } \\
\text { consumed } \\
\text { from } \\
\text { farm/month } \\
\text { (Ksh) }\end{array}$ & $\begin{array}{l}\text { Number of } \\
\text { months } \\
\text { sold }\end{array}$ & $\begin{array}{l}\text { Value } \\
\text { sold/month } \\
\text { (Ksh) }\end{array}$ & $\begin{array}{l}\text { Number of } \\
\text { months } \\
\text { consumed }\end{array}$ & $\begin{array}{l}\text { Value } \\
\text { consumed } \\
\text { from } \\
\text { farm/month } \\
\text { (Ksh) }\end{array}$ \\
\hline & & & & & & \\
\hline
\end{tabular}




\section{Questionnaire number (HHID)}

1.10 Please give the following production and revenue details for other crops grown during both long and short rains seasons last farming year (2014) excluding vegetables

\begin{tabular}{|c|c|c|c|c|c|c|c|c|c|}
\hline \multicolumn{9}{|c|}{ Long rains season (February- August 2014) } & \\
\hline \multirow{2}{*}{$\begin{array}{l}\text { Crop } \\
\text { code }\end{array}$} & \multirow[t]{2}{*}{ Crop name } & \multicolumn{2}{|c|}{$\begin{array}{l}\text { Quantity } \\
\text { produced }\end{array}$} & \multicolumn{2}{|c|}{ Quantity sold } & \multirow{2}{*}{$\begin{array}{l}5 . \\
\text { Average } \\
\text { price } \\
\text { per unit } \\
\text { (Kshs) }\end{array}$} & \multirow{2}{*}{$\begin{array}{l}6 . \\
\text { Highest } \\
\text { price } \\
\text { received } \\
\text { per unit } \\
\text { (Kshs) }\end{array}$} & \multirow{2}{*}{$\begin{array}{l}7 . \\
\text { Lowest } \\
\text { price } \\
\text { received } \\
\text { per unit } \\
\text { (Kshs) }\end{array}$} & $\begin{array}{l}\text { Annua } \\
\text { bonus }\end{array}$ \\
\hline & & $\begin{array}{l}1 . \\
\text { Quantity }\end{array}$ & $\begin{array}{l}\text { 2.Unit } \\
(\text { Unit } \\
\text { code }^{a}\end{array}$ & $\begin{array}{l}3 . \\
\text { Quantity }\end{array}$ & $\begin{array}{l}4 . \\
\text { Units } \\
(\text { Unit } \\
\text { code }^{a}\end{array}$ & & & & $\begin{array}{l}\text { (tea \& } \\
\text { coffee } \\
\text { (Kshs }\end{array}$ \\
\hline 2 & Potatoes (Irish) & & & & & & & & \\
\hline 3 & Sweet potatoes & & & & & & & & \\
\hline 4 & Dry Maize & & & & & & & & \\
\hline 11 & Green Maize & & & & & & & & \\
\hline 5 & Beans & & & & & & & & \\
\hline 6 & Yams & & & & & & & & \\
\hline 12 & Other (Specify1 & & & & & & & & \\
\hline 13 & Other (Specify2 & & & & & & & & \\
\hline
\end{tabular}

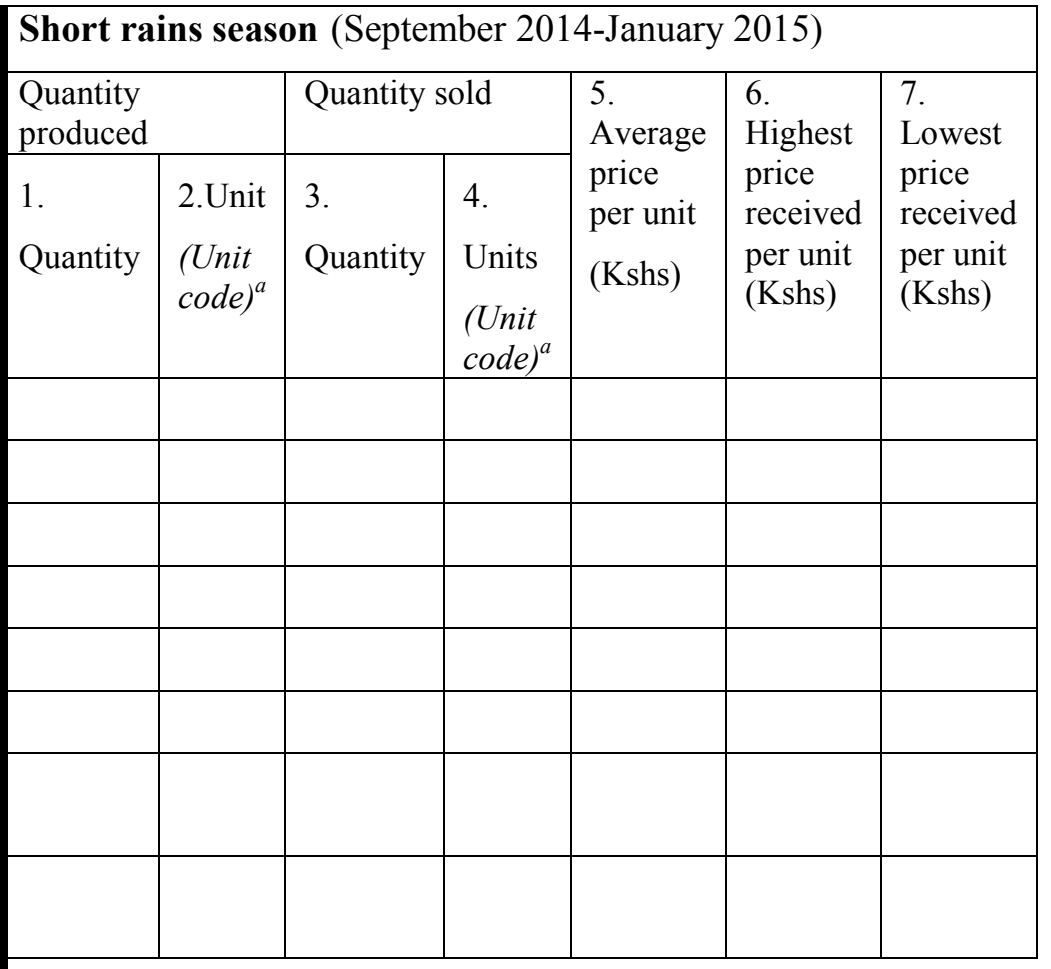

\section{Last farming year (from February 2014-January 2015)}

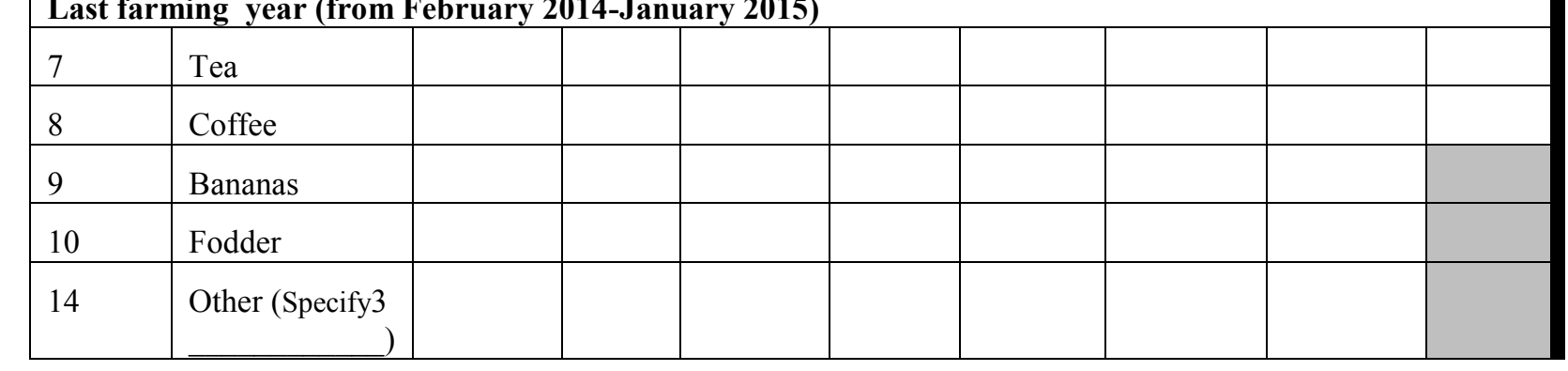

\begin{tabular}{|l|l|l|l|}
\hline \multicolumn{4}{|c|}{${ }^{\text {a }}$ UNIT CODES } \\
\hline 1=Kilogram & $5=90 \mathrm{~kg}$ bag & $9=1 / 4 \mathrm{~kg}$ tin & $13=$ Tones \\
2=5 Kg bag & 6=Debe $(18 \mathrm{kgs})$ & $10=1 / 2 \mathrm{~kg}$ tin & 14=Others(specify) \\
$3=25 \mathrm{Kg}$ & 7=Number $/$ Unit & $11=$ Kg tin & \\
bag & 8=Gorogoro (2.25 & $\begin{array}{l}\text { 12=Bunches(Bananas } \\
\text { only) }\end{array}$ & \\
$4=50 \mathrm{~kg}$ bag & kg tin) & & \\
\hline
\end{tabular}


Questionnaire number (HHID)

1.11 For each crop mentioned above please give details of the cost of production for the crop year 2014/2015. Details should be for all plots and the two crop seasons mentioned above.

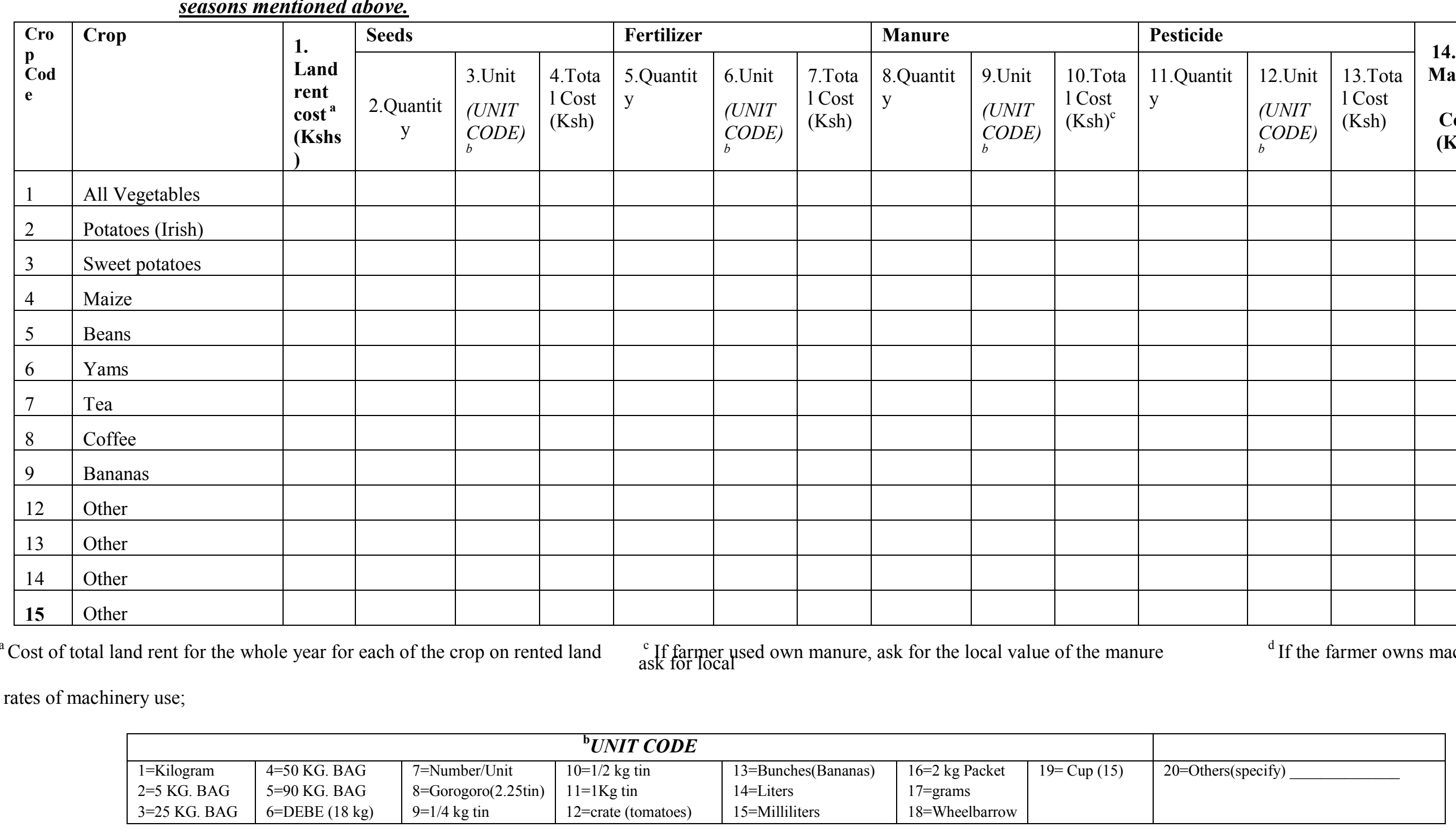


1.12 How many permanent farm workers did you have last year (January 2014-December 2014) and what was their monthly salaries (for both crop \& livestock)?

\begin{tabular}{|c|c|c|c|c|}
\hline $\begin{array}{l}\text { Worker } \\
\text { number }\end{array}$ & $\begin{array}{c}\text { Gender } \\
(0=\text { male }, \\
1=\text { female })\end{array}$ & $\begin{array}{l}\text { Monthly salary } \\
\quad \text { (in Kshs) }\end{array}$ & $\begin{array}{c}\text { Length of employment } \\
\text { Jan-Dec 2014 (In } \\
\text { months) }\end{array}$ & $\begin{array}{l}\text { Type of work }(1=\text { only crops; } \\
2=\text { only livestock; } 3=\text { both })\end{array}$ \\
\hline 1 & & & & \\
\hline 2 & & & & \\
\hline 3 & & & & \\
\hline 4 & & & & \\
\hline 5 & & & & \\
\hline 6 & & & & \\
\hline
\end{tabular}

1.13 Besides permanent workers give the following details on labor use and cost for casual workers employed on your farm for crop production on a weekly basis for last year (January 2014December 2014). (Including both piece rate and daily wage rate)

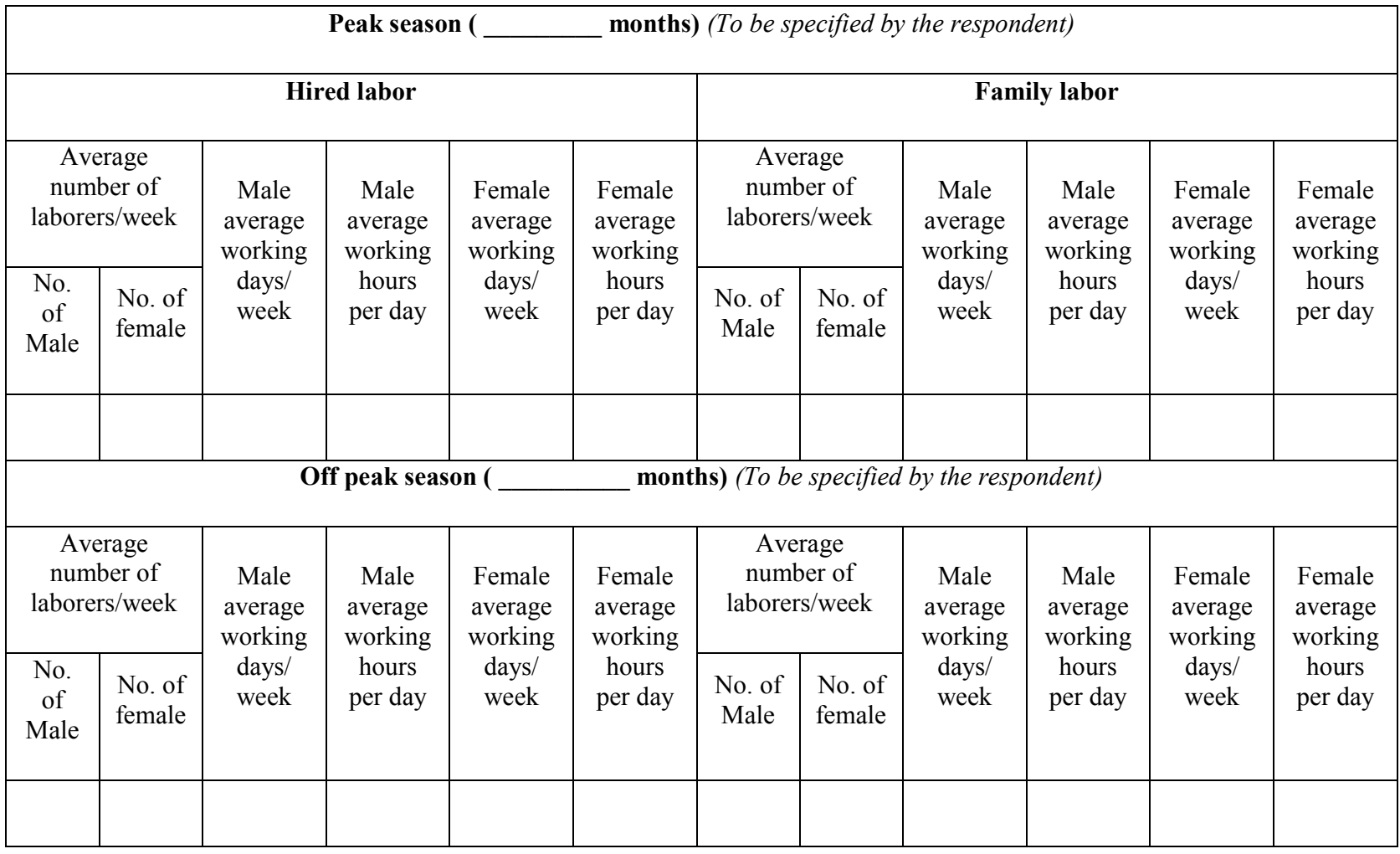

1.14 What is the average daily wage rate for men and women in this area?
Men
$\mathrm{Ksh} /$ day
Women
$\mathrm{Ksh} /$ day

1.16 For the last one year (2014), did you have any livestock on your farm? $(1=$ Yes; $0=N o)$ 
1.17 For the whole of last year (January 2014-Decemeber 2014), please give details of revenue and cost of livestock production?

Please include all animals on the farm last year also those that were later sold or died)

\begin{tabular}{|c|c|c|c|c|c|c|c|c|c|c|}
\hline \multirow[b]{2}{*}{ Animal } & \multirow{2}{*}{$\begin{array}{c}\text { Decision } \\
\text { maker } \\
\text { (MEM- } \\
\text { ID) }\end{array}$} & \multirow{2}{*}{$\begin{array}{l}\text { Number } \\
\text { owned }\end{array}$} & \multirow{2}{*}{$\begin{array}{c}\text { Number } \\
\text { sold }\end{array}$} & \multirow{2}{*}{$\begin{array}{c}\text { Total } \\
\text { revenue } \\
\text { (Ksh) }\end{array}$} & \multirow{2}{*}{$\begin{array}{l}\text { Number } \\
\text { consumed }\end{array}$} & \multirow{2}{*}{$\begin{array}{c}\text { Number } \\
\text { lost }\end{array}$} & \multicolumn{4}{|c|}{ Total Cost of Production (Ksh) } \\
\hline & & & & & & & $\begin{array}{l}\text { Fodder/ } \\
\text { feeds }\end{array}$ & $\begin{array}{c}\text { Labor } \\
\text { (temporary } \\
\text { labor) }\end{array}$ & $\begin{array}{l}\text { Veteri- } \\
\text { nary } \\
\text { care }\end{array}$ & $\begin{array}{l}\text { Other } \\
\text { costs }\end{array}$ \\
\hline \multicolumn{11}{|l|}{ Dairy } \\
\hline \multicolumn{11}{|l|}{ Other } \\
\hline \multicolumn{11}{|l|}{ Goat } \\
\hline \multicolumn{11}{|l|}{ Sheep } \\
\hline \multicolumn{11}{|l|}{ Chicken } \\
\hline \multicolumn{11}{|l|}{ Donkeys } \\
\hline \multicolumn{11}{|l|}{ Pigs } \\
\hline \multicolumn{11}{|l|}{ Rabbits } \\
\hline \multicolumn{11}{|l|}{ Ducks } \\
\hline \multicolumn{11}{|l|}{$\begin{array}{l}\text { Other } \\
\text { specify1 }\end{array}$} \\
\hline \multicolumn{11}{|l|}{$\begin{array}{l}\text { Other } \\
\text { specify2 }\end{array}$} \\
\hline $\begin{array}{l}\text { All listed } \\
\text { above }\end{array}$ & & & & & & & & & & \\
\hline
\end{tabular}

\begin{tabular}{|l|l|l|l|l|}
\hline Animal product/services & 1. Quantity sold & $\begin{array}{l}\text { 2.Units } \\
(\text { UNIT CODE })^{a}\end{array}$ & $\begin{array}{l}\text { 3. Price per unit } \\
(\text { Ksh) }\end{array}$ & $\begin{array}{l}\text { 4. Responsible } \\
\text { (MEMID) }\end{array}$ \\
\hline Milk & & & & \\
\hline Eggs & & & & \\
\hline Hide & & & & \\
\hline Others specify & & & & \\
\hline
\end{tabular}

${ }^{a}$ UNIT CODE (1=litres, $2=$ mililitres, $3=$ Units/numbers, $4=$ Tray $)$

\subsection{SECTION 2: GENERAL INFORMATION ABOUT VEGETABLES}

PLEASE FIND OUT WHO IS IN CHARGE OF VEGETABLE PRODUCTION AND INTERVIEW THIS PERSON.

2.1 Who makes decision about vegetable farming and marketing?

a) Name of decision maker

b) MEMID

(Enumerator Instruction: Record the member number (OPMEM) of the decision maker from the Demography table on page 25 after the survey is completed.)

2.2 How long have you been growing vegetables (as an independent household)?

a) Years:

b) Months: 
2.3 Since 2013, how much of the indigenous and exotic vegetables have you been growing? (Enumerator, ask the farmer to give the average area for each year, considering all seasons)

\begin{tabular}{|l|l|l|l|}
\hline & Area in 2015 (in acres) & Area in 2014 (in acres) & Area in 2013 (in acres) \\
\hline $\begin{array}{l}\text { 1=African indigenous } \\
\text { vegetables }\end{array}$ & & & \\
\hline 2)= Exotic vegetables & & & \\
\hline
\end{tabular}

(African indigenous vegetables are e.g managu, terere, kunde, osuga, pumpkin leaves etc;

Exotic vegetables are e.g spinach, sukuma wiki, lettuce, etc)

2.4 How many vegetable plots did your household have in 2014 main season (Feb. -Aug.)?

2.6 What are the three ways in which most of the money from selling vegetables was used? (1=largest amount of money spent; $2=2^{\text {nd }}$ largest amount of money spent; $3=3^{\text {rd }}$ largest amount of money spent).

\begin{tabular}{|l|l|l|l|l|l|l|l|l|l|l|l|}
\hline $\begin{array}{l}1 . \\
\text { Buy } \\
\text { food }\end{array}$ & $\begin{array}{l}2 . \\
\text { Furniture }\end{array}$ & $\begin{array}{l}\text { 3. Pay } \\
\text { hospital } \\
\text { bill }\end{array}$ & $\begin{array}{l}4 . \\
\text { Pay } \\
\text { rent }\end{array}$ & $\begin{array}{l}5 . \text { Pay } \\
\text { Dowry }\end{array}$ & $\begin{array}{l}6 . \\
\text { Leisure }\end{array}$ & $\begin{array}{l}7 . \quad \text { Land } \\
\text { preparation }\end{array}$ & $\begin{array}{l}8 . \\
\text { Buy } \\
\text { farm } \\
\text { input }\end{array}$ & $\begin{array}{l}9 . \\
\text { Pay } \\
\text { loans }\end{array}$ & $\begin{array}{l}10 . \\
\text { School } \\
\text { fees }\end{array}$ & $\begin{array}{l}11 . \\
\text { Clothing }\end{array}$ & $\begin{array}{l}12 . \\
\text { (specify__ Others }\end{array}$ \\
\hline & & & & & & & & & & & \\
\hline
\end{tabular}

2.7 For the present season (March-August 2015), how much of your vegetable area is irrigated?
a) Area:
b) Unit:
$\left(1=\right.$ acres, $2=m^{2}, 3=H a, 4=$ feet $\left.^{2}\right)$

2.8 From where do you get information on production of vegetables such as information on production techniques, new seeds, pest control, input use etc.? (Rank three most important sources $)\left(1=\right.$ most important source, $2=2^{\text {nd }}$ most important, etc. $)$

\begin{tabular}{|l|l|}
\hline \multicolumn{1}{|c|}{ 1) Government extension (field days etc.) } & Rank (1-3) \\
\hline 2) Agricultural cooperative & \\
\hline 3) NGO (Please specify) & \\
\hline 4) Input dealer & \\
\hline 5) Members of my farmers' group & \\
\hline 6) Other farmers (e.g., neighbors, but non-group members) & \\
\hline 7) Public gathering (barazas) & \\
\hline 8) Public media (e.g., radio, newspaper, magazines) & \\
\hline 9) Traders & \\
\hline 10) Contracting retailer (supermarket, export companies, etc.) & \\
\hline 11)Agricultural seminars, workshops, group trainings & \\
\hline 12) Own experience & \\
\hline 13) Other (please specify): & \\
\hline
\end{tabular}

2.9 When it comes to obtaining new information about production of vegetables, would you say that it is very difficult, difficult, easy or very easy for you to obtain such information?

$(\mathbf{1}=$ Very difficult; $\mathbf{2}=$ Difficult; $\mathbf{3}=$ Easy; $\mathbf{4}=$ Very easy $)$ 
2.10 What kind of production information do you feel you are lacking?

\begin{tabular}{|l|l|}
\hline Type of production information lacking & $\begin{array}{l}\boldsymbol{I}=\boldsymbol{Y} \boldsymbol{E} ; \\
\boldsymbol{O}=\boldsymbol{N O} \boldsymbol{O}\end{array}$ \\
\hline 1. New varieties & \\
\hline 2. $\quad$ Correct pesticide & \\
\hline 3. Production techniques & \\
\hline 4. $\quad$ Credit possibilities & \\
\hline 5. Selection of good seed & \\
\hline 6. Use of inorganic/ organic fertilizer & \\
\hline 7. Others (specify) & \\
\hline
\end{tabular}

\subsection{SECTION 4: INPUT AND OUTPUT DATA FOR VEGETABLE PRODUCTION}

The following questions relate to the present season (March-August 2015). 1. Farmers supplying supermarkets (direct or indirect) should give information for the main vegetables that they mostly supply to supermarket. 2. Farmers supplying to institutions and companies should give information on the main vegetables that they mostly supply to institutions and companies (unless they supply to supermarkets). 3. The rest of the farmers should give information about their main vegetable to the traditional market.

3.26 For this season (March-August 2015), where do you sell/plan to sell your vegetables? (Please choose the three markets where you sell most quantities and rank them in order of importance)

\begin{tabular}{|c|c|}
\hline Market Channels & 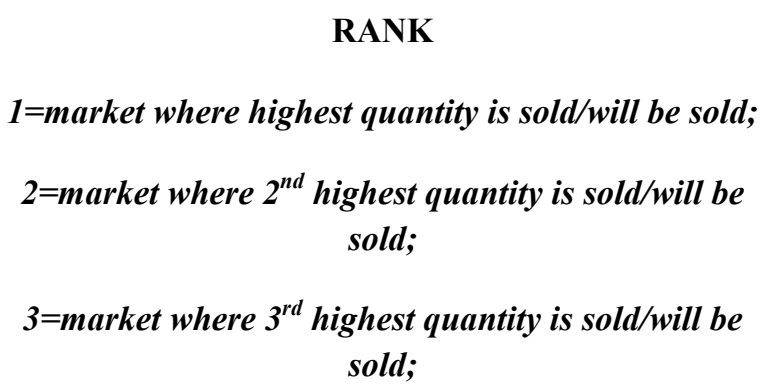 \\
\hline 1. The supermarkets & \\
\hline 2. Traders/brokers to supermarkets & \\
\hline 3. Companies and institutions & \\
\hline 4. Independent middlemen or traders & \\
\hline 5. Spot market & \\
\hline 6. Others (specify) & \\
\hline
\end{tabular}


4.1 Which are the three main vegetables that you sell/will sell in highest volume to your most preferred market (as noted in 4.26; please note: current season March-August 2015)?

Please rank so that 1 gives the most preferred, 2 the $2^{\text {nd }}$ most and 3 the third most preferred vegetable.

\begin{tabular}{|c|c|c|c|c|c|}
\hline Vegetable & $\begin{array}{c}\text { Rank } \\
\text { of crop }\end{array}$ & Vegetable & $\begin{array}{c}\text { Rank } \\
\text { of crop }\end{array}$ & & $\begin{array}{c}\text { Rank } \\
\text { of crop }\end{array}$ \\
\hline 1) Managu & & 5) Kales (Sukuma & & 9) Brocolli & \\
\hline 2) Sargeti & & 6) Cabbage & & 10)Lettuce & \\
\hline 3) Terere & & 7) Spinach & & 11)Others: & \\
\hline $\begin{array}{l}\text { 4) Thoroko (cow pea } \\
\text { leaves) }\end{array}$ & & $\begin{array}{l}\text { 8) Dhania } \\
\text { (Corriander) }\end{array}$ & & 12)Others: & \\
\hline
\end{tabular}


Please identify up to three plots where vegetables are grown and ask the following questions at the site of these plots. Please start with the vegetable

identified in 3.1 as most important. (If more than one plot, please choose the plots based on the last digit of the HHID).

4.2 Please give the following information starting with the plot that contains the main vegetable sold in terms of volume to the most preferred market.

Continue with the second and third most important vegetables in terms of marketed volume.

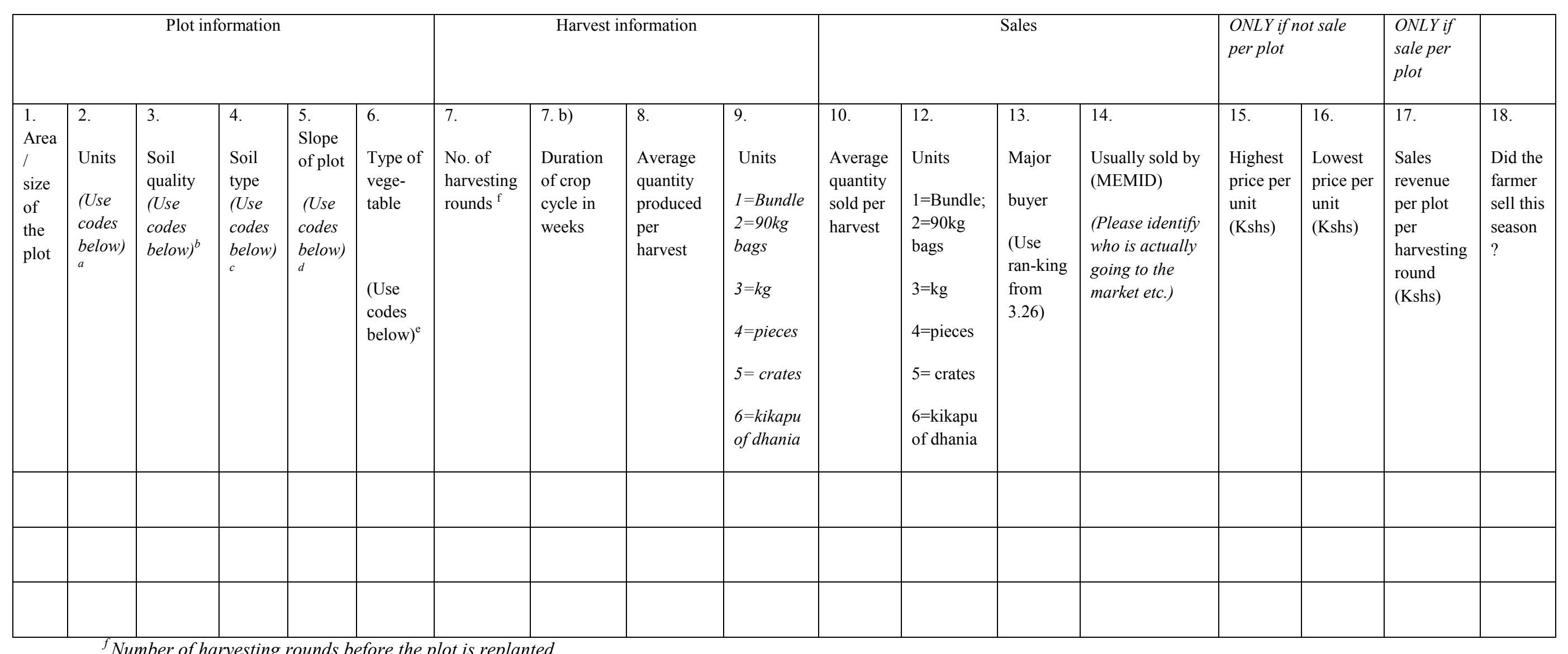

${ }^{f}$ Number of harvesting rounds before the plot is replanted 


\begin{tabular}{|c|c|c|c|c|c|}
\hline${ }^{a}$ Land unit codes: & \multicolumn{2}{|c|}{${ }^{b}$ Soil quality codes: } & \multicolumn{2}{|l|}{ Soil type codes: } & ${ }^{d}$ Slope codes: \\
\hline $\begin{array}{l}1=\text { acres, } \\
2=m 2, \\
3=H a\end{array}$ & $\begin{array}{l}1=\text { highly fertil } \\
2=\text { medium ferti } \\
3=\text { low fertile. }\end{array}$ & & $\begin{array}{l}1=\text { black cotton soil, } \\
2=\text { clay soil, } \\
3=\text { loam soil, }\end{array}$ & $\begin{array}{l}4=\text { sandy soil, } \\
5=\text { other }, \text { specify }\end{array}$ & $\begin{array}{l}1=\text { steeply sloped plot }, \\
2=\text { gently sloped plot }, \\
3=\text { plot on flat ground } .\end{array}$ \\
\hline \multicolumn{4}{|l|}{${ }^{e}$ Vegetable codes: } & & \\
\hline $\begin{array}{l}1=\text { Managu } \\
2=\text { Sargeti, } \\
3=\text { Terere, } \\
4=\text { Thoroko (cow } \\
\text { pea leaves), }\end{array}$ & $\begin{array}{l}5=\text { Kales } \\
\text { (Sukuma wiki), } \\
6=\text { Cabbage, } \\
7=\text { Spinach } \\
8=\text { Cauliflower }\end{array}$ & $\begin{array}{l}9=\text { Dhania (Corriander) } \\
10=\text { Brocolli, } \\
11=\text { Lettuce, } \\
12=\text { others }, \\
\text { specify }\end{array}$ & $\begin{array}{l}13=\text { others, } \\
\text { specify } \\
14=\text { others, } \\
\text { specify }\end{array}$ & & \\
\hline
\end{tabular}

4.3 If output is measured in bags, approximately how many bundles can one make from one bag of vegetables?

Plot 1: bundles

Plot 2:

bundles Plot3: bundles

4.4 How many leaves/stems of this vegetable make one bundle?

$$
\text { Plot1: }
$$
leaves/stems

Plot2: leaves/stems Plot3: leaves/stems

2.5 Please tell me (for $\mathbf{2 0 1 5}$ main season) who makes the decisions about production, sales and revenue spending for each plot:

\begin{tabular}{|c|c|c|c|}
\hline $\begin{array}{l}\text { Plot } \\
\text { No. }\end{array}$ & $\begin{array}{l}\text { Who made the decisions about the production on } \\
\text { this plot? } \\
\text { (I.e. when, where, how much and what type of } \\
\text { vegetable to grow) }\end{array}$ & $\begin{array}{l}\text { Who made decisions about the output from this } \\
\text { plot? } \\
\text { (I.e. how much to sell, how much to use for home } \\
\text { consumption where and when to sell)? }\end{array}$ & $\begin{array}{l}\text { Who decided how to use the revenues from sales } \\
\text { from this plot? } \\
\text { (Decision maker codes below) }^{c}\end{array}$ \\
\hline
\end{tabular}




\begin{tabular}{|l|l|l|l|}
\hline & ${\text { (Decision maker codes below })^{c}}^{c}$ & ${\text { (Decision maker codes below })^{c}}$ & \\
\hline Plot1 & & & \\
\hline Plot2 & & & \\
\hline Plot3 & & & \\
\hline
\end{tabular}

\section{${ }^{c}$ DECISION MAKER CODE:}

$1=$ Husband alone made the decisions,

$2=H u s b a n d$ was the major decision maker after

consulting with wife,
$3=$ Wife alone made the decisions,

$4=$ Wife was the major decision maker after

consulting with husband
5=Someone else makes decision ( use MEMID

where not applicable specify who, including

gender and relation to Husband, e.g. daughter) 


\section{Questionnaire number (HHID)}

4.5. For the first plot, please specify all inputs that you use during the entire crop cycle, their prices per unit, and the total amount of money spent on this plot? Please give information for one full plot planted at_once.

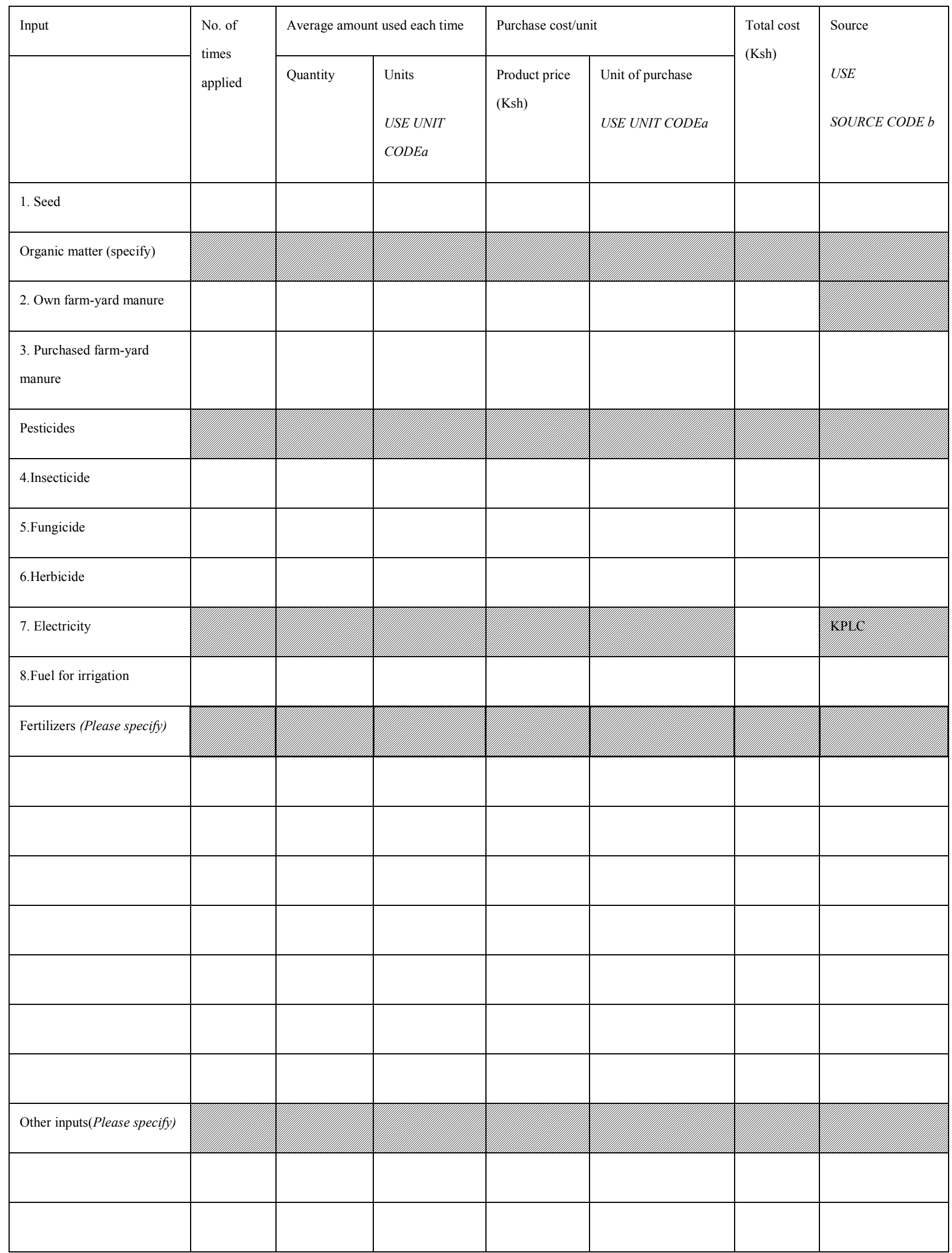




\begin{tabular}{|c|c|c|c|c|c|}
\hline \multicolumn{5}{|c|}{${ }^{a}$ UNIT CODE } & ${ }^{\mathrm{b}}$ SOURCE CODE \\
\hline $\begin{array}{l}\text { 1=Kilogram } \\
2=5 \mathrm{KG} \\
\text { bag } \\
3=25 \mathrm{KG} \\
\text { bag }\end{array}$ & $\begin{array}{l}4=50 \\
\text { KG bag } \\
5=90 \\
\text { KG bag } \\
6=\mathrm{DEBE} \\
(18 \mathrm{~kg})\end{array}$ & $\begin{array}{l}7=\text { Number } / \text { Unit } \\
8=\text { Gorogoro }(2.25 \text { tin }) \\
9=1 / 4 \mathrm{~kg} \text { tin } \\
10=1 / 2 \mathrm{~kg} \text { tin } \\
11=1 \mathrm{Kg} \text { tin }\end{array}$ & $\begin{array}{l}13=\text { Litres } \\
14=\text { Mililitres } \\
15=2 \mathrm{~kg} \text { Packet }\end{array}$ & $\begin{array}{l}16=\text { grams } \\
17=\text { Wheelbarrow } \\
18=\text { Others } \\
\text { (specify) }\end{array}$ & $\begin{array}{l}1=\text { input dealer; } 2=\mathrm{NGO} ; \\
3=\text { trader; } 4=\text { fellow } \\
\text { farmers; } 5=\text { informal } \\
\text { market; } 6=\text { others } \\
\text { specify }\end{array}$ \\
\hline
\end{tabular}


4.7 For the first plot, please specify how often the following operations were/are carried out for one complete growing cycle. Please give information for one full plot planted at once.

\begin{tabular}{|c|c|c|c|c|c|c|c|}
\hline \multirow[t]{2}{*}{ Farm activities } & \multirow{2}{*}{$\begin{array}{c}\text { How } \\
\text { many } \\
\text { times? }\end{array}$} & \multicolumn{2}{|c|}{$\begin{array}{l}\text { Average no. of } \\
\text { persons involved } \\
\text { each time }\end{array}$} & \multirow{2}{*}{$\begin{array}{c}\text { Average } \\
\text { no. of } \\
\text { days each } \\
\text { time }\end{array}$} & \multirow{2}{*}{$\begin{array}{c}\text { Average } \\
\text { No. of } \\
\text { hours per } \\
\text { day }\end{array}$} & \multicolumn{2}{|c|}{$\begin{array}{l}\text { How many of those are } \\
\text { usually hired laborers? }\end{array}$} \\
\hline & & Male & Female & & & Male & Female \\
\hline 1. Land preparatio & & & & & & & \\
\hline 2. Planting & & & & & & & \\
\hline 3. Gap filling & & & & & & & \\
\hline 4. Manual weeding & & & & & & & \\
\hline 5. Irrigating & & & & & & & \\
\hline 6. Fertilizer applic & & & & & & & \\
\hline 7. Pesticide applic & & & & & & & \\
\hline 8. Other chemicals & & & & & & & \\
\hline 9. Harvesting & & & & & & & \\
\hline 10. Cleaning and $p$ & & & & & & & \\
\hline 11.Other, specify: & & & & & & & \\
\hline
\end{tabular}

4.8 In general, what method of land preparation (plowing and harrowing) do you use? $(0=$ None, $1=$ Tractor $2=$ Animal traction $3=$ Manual $/$ hand $)$

4.9 If you use tractor or animal traction how much do you pay for this service? (Ksh/acre). (If the farmer owns tractor or animals, what is the local rate for these services?)

4.10 Generally, how many times in a year do you grow the vegetable on the first plot?

\section{SECTION 3: INFORMATION ON MARKETING OF VEGETABLES}

3.1 Are you always able to sell all your vegetable that you wish to sell? QN: 3.3) $(1=$ YES, 0=NO) (IF YES; SKIP TO

3.2 If no, please give reasons why you are unable to sell.

\begin{tabular}{|c|c|c|}
\hline Reasons & $\begin{array}{c}1=Y E S \\
0=N O\end{array}$ & $\begin{array}{l}\text { On a scale from } 1 \\
\text { (very small) to } 5 \\
\text { (very big) how big } \\
\text { is the problem? }\end{array}$ \\
\hline 1. The price is unbearably low & & \\
\hline 2. There is no willing buyer (lack of market) & & \\
\hline
\end{tabular}




\begin{tabular}{|l|l|l|}
\hline 3. I have no means of transporting & & \\
\hline 4. Too much supply on the market (flooded market) & & \\
\hline 5. Some of the produce is rejected by the buyer because of quality & & \\
\hline 6. Others (Specify1) & & \\
\hline 7. Others (specify2) & & \\
\hline
\end{tabular}

3.3 Whenever you want to sell your vegetables, where do you get information on possible market opportunities and market prices? (Rank three most important sources)

(Ranks: $1=$ most important source; $2=2^{\text {nd }}$ most important source; $3=3^{\text {rd }}$ most important source.)

\begin{tabular}{|l|l|}
\hline Source of market information & Rank (1-3) \\
\hline 1. From fellow farmers' group members & \\
\hline 2. Other farmers, who are not members of my group & \\
\hline 3. From cooperative society & \\
\hline 4. From agricultural extension staff & \\
\hline 5. From NGO (Specify) & \\
\hline 6. From public media (radio, television, smart farmer, internet etc.) & \\
\hline 7. From public gatherings (chief's baraza etc.) & \\
\hline 8. Agricultural seminars, workshops, group trainings & \\
\hline 9. From traders & \\
\hline 10. Others (specify) & \\
\hline
\end{tabular}

3.4 When it comes to obtaining new information about marketing opportunities and prices for vegetables, would you say that it is very difficult, difficult, easy or very easy for you to obtain such information?

$(\mathbf{1}=$ Very difficult; $\mathbf{2}=$ Difficult; $\mathbf{3}=$ Easy; $\mathbf{4}=$ Very easy $)$

3.5 What kind of marketing information do you feel you are lacking?

\begin{tabular}{|c|c|c|}
\hline Type of marketing information lacking & $\begin{array}{l}1=Y e s ; \\
0=N o\end{array}$ & $\begin{array}{l}\text { On a scale from } \\
1 \text { (very small) to } \\
5 \text { (very big) how } \\
\text { big is the } \\
\text { problem? }\end{array}$ \\
\hline 1. Market opportunities (where to sell) & & \\
\hline 2. Prices & & \\
\hline 3. Market requirements or standards & & \\
\hline 4. Other (please specify) & & \\
\hline
\end{tabular}


Please tell me details about marketing of vegetables produced during 2014 crop year (February 2014 to January 2015)

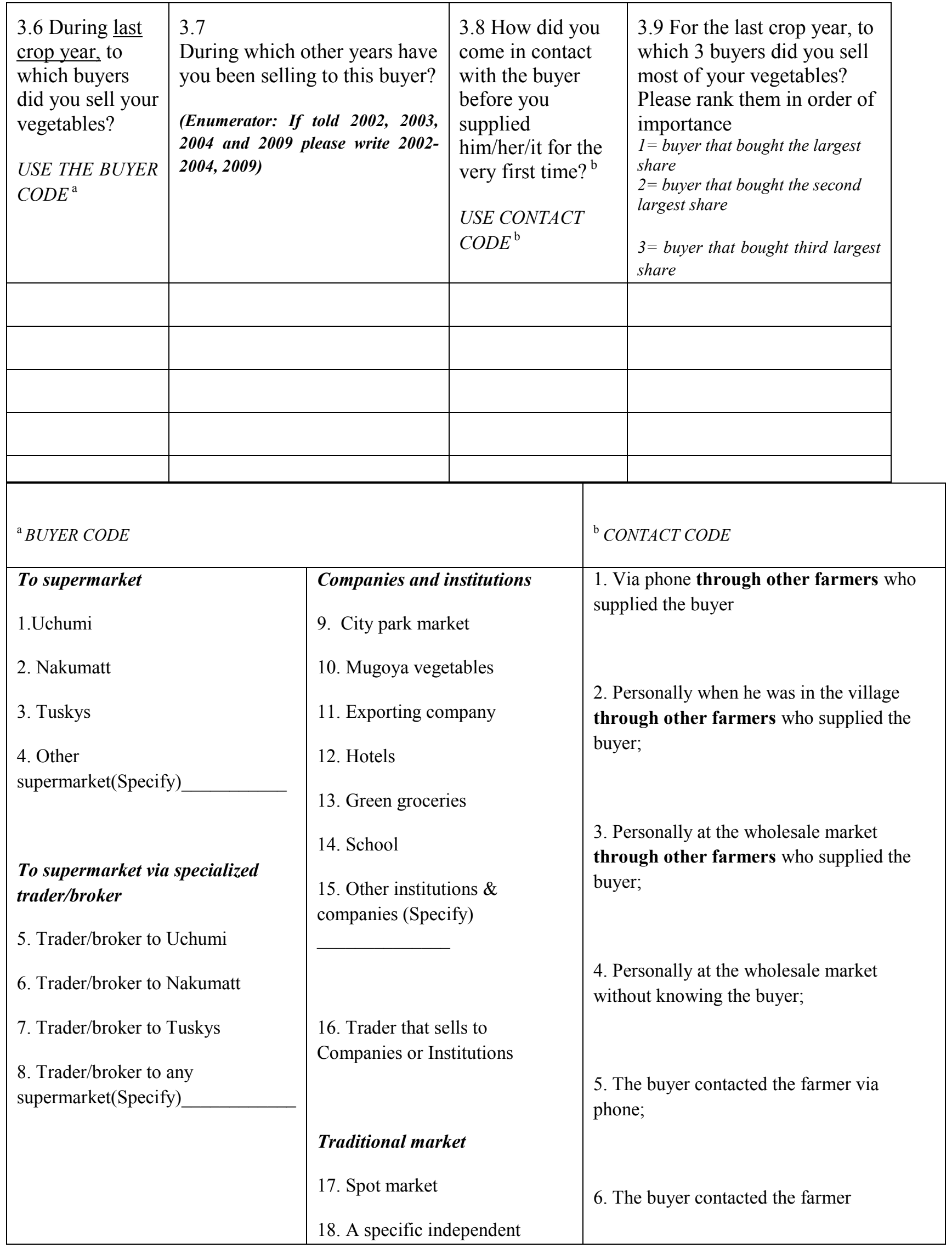




\begin{tabular}{|l|l|l|}
\hline & $\begin{array}{l}\text { middleman or broker } \\
\text { 19. Various independent brokers } \\
\text { or middlemen } \\
20 . \text { Other } \\
\text { (Specify) }\end{array}$ & 7. Other specify \\
& & \\
\hline
\end{tabular}




\section{Questionnaire number (HHID)}

Please tell me more details about your 3 most important buyers (listed in 3.9):

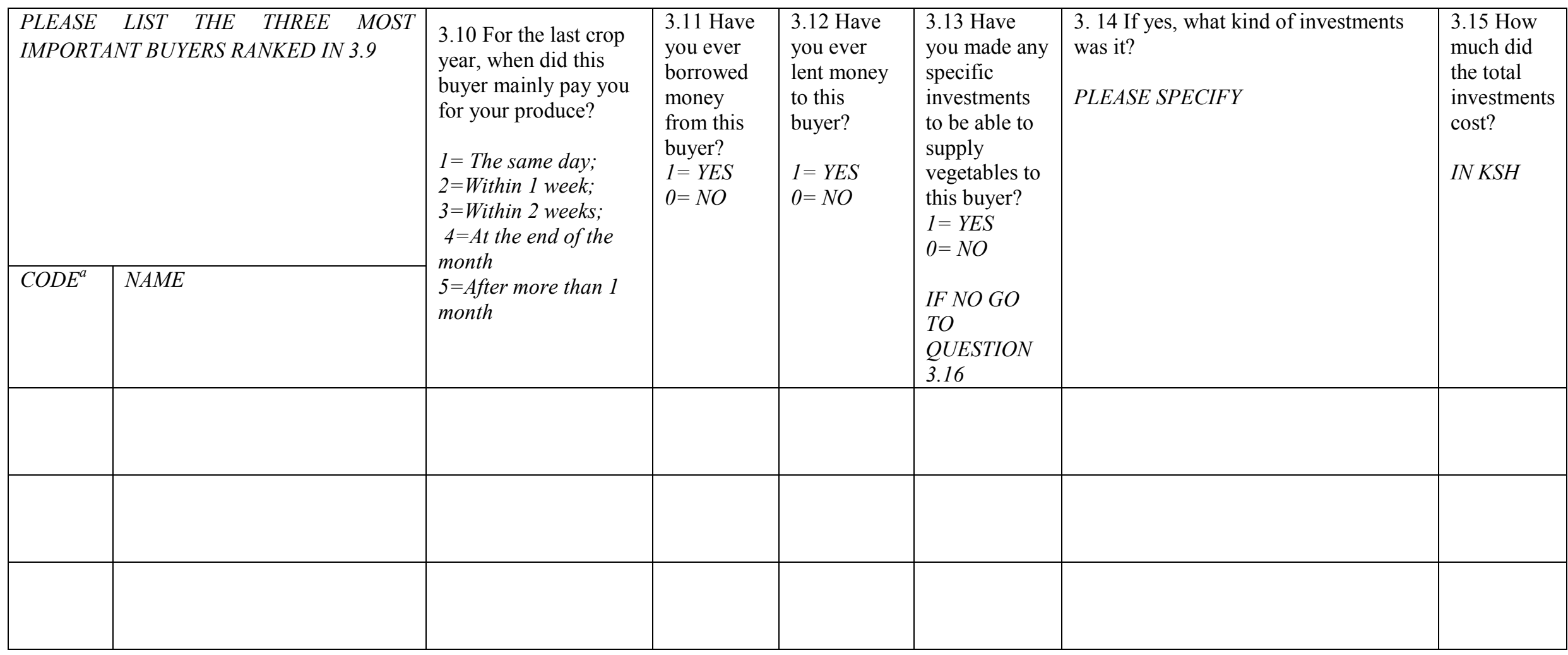


3.16 Now we are interested in your reasons for selling to different buyers

\begin{tabular}{|c|c|c|c|}
\hline $\begin{array}{l}\text { PLEASE FILL IN THE NAME OF THE BUYER } \\
\text { BASED ON OUESTION 3.9-> }\end{array}$ & Name: & Name: & Name: \\
\hline CODES: & $\begin{array}{l}\text { Buyer ranked } \\
\text { No. } 1 \text { in question } \\
3.9\end{array}$ & $\begin{array}{l}\text { Buyer ranked } \\
\text { No. } 2 \text { in question } \\
3.9\end{array}$ & $\begin{array}{l}\text { Buyer ranked } \\
\text { No. } 3 \text { in question } \\
3.9\end{array}$ \\
\hline $\begin{array}{l}0=\text { if reason is not mentioned } \\
\text { If reason is mentioned: } \\
\text { On a scale from 1, very small advantage of } \\
\text { this buyer, to } 5, \text { very big advantage of this } \\
\text { buyer, how important is this }\end{array}$ & $\begin{array}{l}\text { Why did you sell } \\
\text { vegetables to }\end{array}$ & $\begin{array}{l}\text { Why did you sell } \\
\text { vegetables to }\end{array}$ & $\begin{array}{l}\text { Why did you } \\
\text { sell vegetables } \\
\text { to }\end{array}$ \\
\hline 1. The buyer offers a high price & & & \\
\hline 2. The buyer pays a stable price & & & \\
\hline $\begin{array}{l}\text { 3. The buyer does not manipulate price (does not } \\
\text { change price arbitrarily) }\end{array}$ & & & \\
\hline 4. I can negotiate price with the buyer & & & \\
\hline 5. The buyer pays promptly & & & \\
\hline $\begin{array}{l}\text { 6. The buyer will always buy the produce (market } \\
\text { assurance) }\end{array}$ & & & \\
\hline $\begin{array}{l}\text { 7. The buyer is not strict on the quality of products, } \\
\text { so I can sell all my produce }\end{array}$ & & & \\
\hline $\begin{array}{l}\text { 8. I do not have to worry about breakages/spoilage } \\
\text { after selling }\end{array}$ & & & \\
\hline 9. We have a long standing trading relationship & & & \\
\hline 10. The buyer is well known in the village & & & \\
\hline 11. We are friends or relatives & & & \\
\hline 12. Welfare or financial support, e.g. advance & & & \\
\hline $\begin{array}{l}\text { 13. The buyer provide me with knowledge about } \\
\text { production methods }\end{array}$ & & & \\
\hline 14. I have no other alternative market (buyer) & & & \\
\hline $\begin{array}{l}\text { 15. I cannot supply more to other buyers that I would } \\
\text { rather sell to }\end{array}$ & & & \\
\hline $\begin{array}{l}\text { 16. I have no means of transporting vegetables to } \\
\text { other markets }\end{array}$ & & & \\
\hline 17. Other reasons (specify) & & & \\
\hline
\end{tabular}


IF THE RESPONDENT SOLD AT LEAST SOME VEGETABLES TO SUPERMARKETS DURING THE LAST CROP YEAR: PLEASE GO TO QUESTION 3.21

3.17 Do you know that you can sell vegetables to supermarkets?

$$
\text { (1=YES; } \quad 0=\mathrm{NO}->\text { go to question 3.22) }
$$

3.18 Why did you not supply your vegetables to supermarkets?

\begin{tabular}{|c|c|c|}
\hline Reasons: & $\begin{array}{l}\text { PLEASE FILL IN } \\
1=\text { if reason is mentioned } \\
0=\text { if reason is not } \\
\text { mentioned }\end{array}$ & $\begin{array}{l}\text { PLEASE FILL IN } \\
\text { On a scale from } 1 \text { to } 5 \text { how } \\
\text { big is the problem? (Where } \\
1 \text { is very small and } 5 \text { very } \\
\text { big) }\end{array}$ \\
\hline 1. Do not pay prompt & & \\
\hline 2. Cheats on the timir & & \\
\hline 3. Too much variation & & \\
\hline 4. Cheats on price ag, & & \\
\hline 5. Offers low price & & \\
\hline 6. Demand too strict & & \\
\hline 7. Rejects too much o & & \\
\hline 8. Cheats on quality a & & \\
\hline 9. Farmer is unable to & & \\
\hline 10. Buys too small qua & & \\
\hline 11. Too much damage & & \\
\hline 12. Cheating on damag & & \\
\hline 13. Difficult to get the & & \\
\hline 14. Require reliable $\mathrm{m}$ & & \\
\hline 15. Time consuming / & & \\
\hline 16. Capital intensive & & \\
\hline 17. Others (specify 1 ) & & \\
\hline 18. Others (specify 2) & & \\
\hline
\end{tabular}

3.19 Have you ever supplied to supermarkets? $(1=Y E S ; 0=N O)$ IF NO SKIP TO 3.21

3.20 If yes, during which years? $2012 \ldots 2013 \_2014 \ldots 2015$ (Enumerator: Please make sure that all years are included; " 1 " if farmer supplied and " 0 " if not)

3.21 Have you ever been rejected to supply to supermarkets? $(1=Y E S ; 0=N O)$ 
3.22 When selling your vegetables to (buyer ranked one, supermarket or companies and institutions), when do you agree on...?

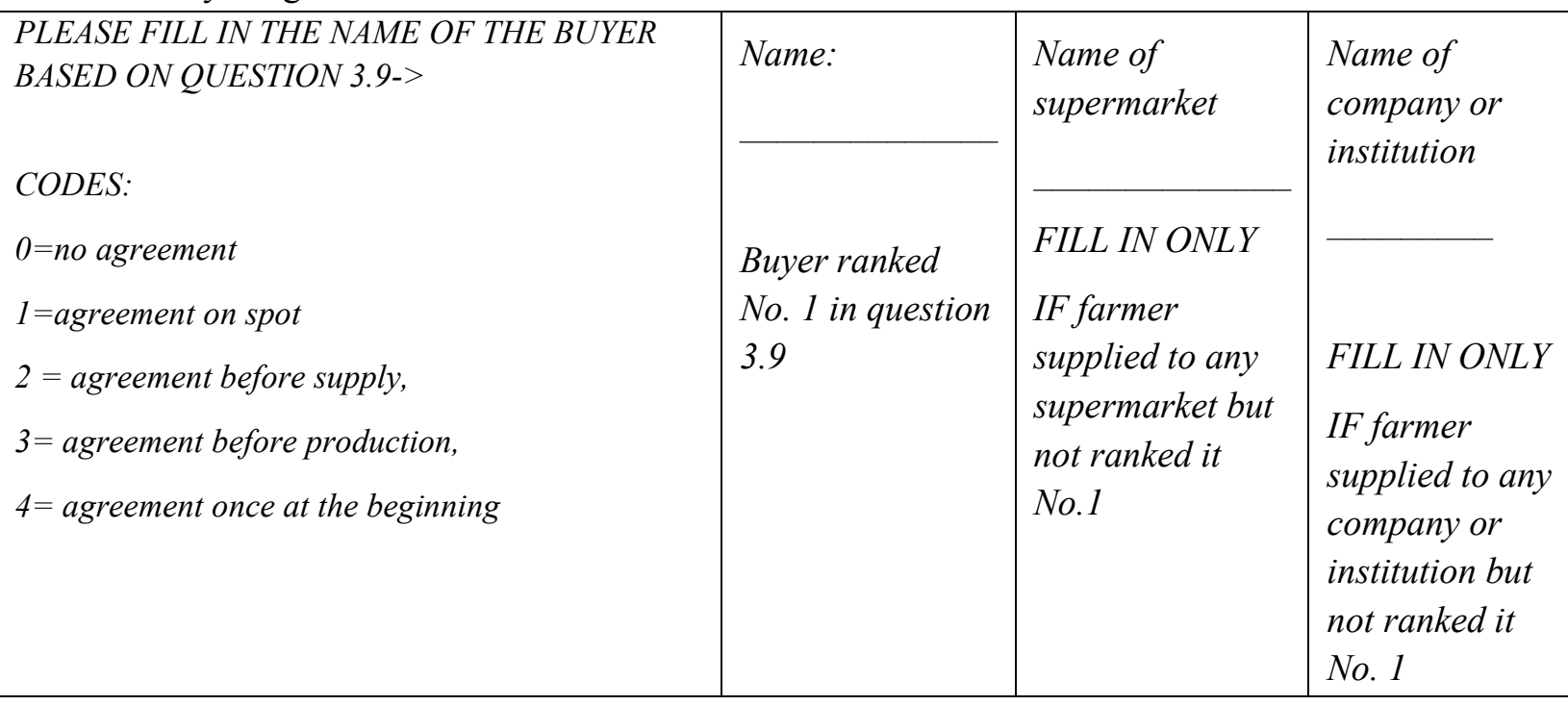

\section{Agreement on transaction (Transaction attributes)}

\begin{tabular}{|l|l|l|l|}
\hline 1. On type of vegetable & & & \\
\hline 2. On price & & & \\
\hline 3. On quantity & & & \\
\hline 4. To supply continuously (all year round) & & & \\
\hline 5. To deliver regularly (twice/week etc.) & & & \\
\hline 6. On production technique & & & \\
\hline 7. Mode of payment (e.g. cash/cheque/m-pesa) & & & \\
\hline 8. Specific plot to be used for production & & & \\
\hline 9. I should have a cell phone for receiving orders & & & \\
\hline 10. No side-selling & & & \\
\hline 11. Time of delivery & & & \\
\hline 12. Time of payment & & & \\
\hline 13. Other ( specify & & & \\
\hline Agreement of product attributes & & & \\
\hline 1. Vegetable should be harvested at certain age & & & \\
\hline 2. Deliver fresh produce (delivered within hours & & & \\
\hline 3. Ve harvesting) & & & \\
\hline 4. Vegetable should be cleaned before delivery & & & \\
\hline 5. Vegetable should be packed in certain quantity & & & \\
\hline 6. Minimum pesticide use & & & \\
\hline 7. Others (specify & & & \\
\hline
\end{tabular}


3.23 Please give more details of the agreement and rejection rates (to be asked for all buyers except Spot market)

\begin{tabular}{|c|c|c|c|}
\hline $\begin{array}{r}\text { PLEASE FILL IN THE NAME OF THE BUYERS } \\
\text { BASED ON QUESTION } 3.9 \text {-> }\end{array}$ & $\begin{array}{l}\text { Buyer ranked } \\
\text { No. } 1 \text { in question } \\
3.9 \\
\text { Not applicable if } \\
\text { spot market. }\end{array}$ & $\begin{array}{l}\text { FILL IN ONLY } \\
\text { IF farmer } \\
\text { supplied to any } \\
\text { supermarket but } \\
\text { not ranked it } \\
\text { No.1 }\end{array}$ & $\begin{array}{l}\text { FILL IN } \\
\text { ONLY } \\
\text { IF farmer } \\
\text { supplied to } \\
\text { any } \\
\text { company } \\
\text { or } \\
\text { institution } \\
\text { but not } \\
\text { ranked it } \\
\text { No. } 1\end{array}$ \\
\hline $\begin{array}{l}\text { 1. If there was an agreement, was it oral or written? } \\
1=\text { Oral, } 2=\text { Written } 3=\text { Partly oral and partly written }\end{array}$ & & & \\
\hline $\begin{array}{l}\text { 2. If there was an agreement, what would have happened } \\
\text { if you were unable to fulfill the agreement? } \\
\text { USE THE CONSEQUENCE CODE a (multiple codes } \\
\text { possible) }\end{array}$ & & & \\
\hline $\begin{array}{l}\text { 3. If there was an agreement, how many times during } \\
\text { last season were you unable to deliver upon request? } \\
\text { IN NUMBER OF TIMES }\end{array}$ & & & \\
\hline In general.... & & & \\
\hline $\begin{array}{l}\text { 4. During last season, how much of your product } \\
\text { was rejected? } \\
\text { IN PERCENT }\end{array}$ & & & \\
\hline $\begin{array}{l}\text { 5. Did you agree on the rejection? } \\
1=Y E S ; 0=N O\end{array}$ & & & \\
\hline $\begin{array}{l}\text { 6. How often has the buyer been to your farm in the } \\
\text { last one year? } \\
(1=\text { Never } ; \quad 2=\text { Once; } \quad 3=\text { More than once) }\end{array}$ & & & \\
\hline
\end{tabular}

\begin{tabular}{|ll|}
\hline${ }^{a}$ CONSEQUENCE CODE \\
\hline 1 = Nothing happens & $5=$ I will have to pay back next season \\
$2=$ I will immediately lose the opportunity to supply to the & $6=$ It will be pressure from the buyer \\
buyer & $7=$ It will be pressure from other farmers \\
\hline
\end{tabular}


$3=$ I will eventually lose the opportunity to supply to the buyer $8=$ Other(specify)

$4=$ I will have to pay a fee

3.24 Did you receive any other services or assistance from the buyers of your vegetables?

\begin{tabular}{|c|c|c|c|}
\hline $\begin{array}{l}\text { PLEASE FILL IN THE NAME OF THE BUYERS } \\
\text { BASED ON QUESTION } 3.9\end{array}$ & Name: & $\begin{array}{l}\text { Name of } \\
\text { supermarket }\end{array}$ & Name of company \\
\hline $\begin{array}{l}0=\text { if service/assistance is not mentioned } \\
\text { If reason is mentioned: } \\
\text { On a scale from 1, very small, to } 5 \text {, very big, } \\
\text { how big was it }\end{array}$ & $\begin{array}{l}- \\
\text { Buyer ranked } \\
\text { No. } 1 \text { in } \\
\text { question } 3.9\end{array}$ & $\begin{array}{l} \\
\text { FILL IN ONLY } \\
\text { IF farmer } \\
\text { supplied to any } \\
\text { supermarket } \\
\text { but not ranked } \\
\text { it No.1 }\end{array}$ & $\begin{array}{l} \\
\text { FILL IN ONLY } \\
\text { IF farmer } \\
\text { supplied to any } \\
\text { company or } \\
\text { institution but not } \\
\text { ranked it No. } 1\end{array}$ \\
\hline I received service or assistance on; & & & \\
\hline 1. Seeds supply & & & \\
\hline 2. Pesticide supply & & & \\
\hline 3. Fertilizer supply & & & \\
\hline 4. Information on production techniques & & & \\
\hline 5. Credit on output (welfare support) & & & \\
\hline 6. Loan guarantee & & & \\
\hline 7. Advances on crop production & & & \\
\hline 8. Market information (output) & & & \\
\hline 9. Market information (input) & & & \\
\hline 10. Harvest & & & \\
\hline 11. Transportation to market & & & \\
\hline 12. Other assistance (specify & & & \\
\hline
\end{tabular}


3.25 Please list any problems or complaints/ dissatisfaction that you have about the top ranked buyers of vegetables in question 3.9? (Please rank your complaints/problems).

\begin{tabular}{|c|c|c|c|}
\hline $\begin{array}{l}\text { PLEASE FILL IN THE NAME OF THE BUYERS } \\
\text { ACCORING TO THE RANKING IN QUESTION } \\
\text { 3.9 } \\
0=\text { if reason is not mentioned } \\
\text { If reason is mentioned: } \\
\text { On a scale from 1, very small, to 5, very big, } \\
\text { how big is this problem? }\end{array}$ & $\begin{array}{l}\text { Name: } \\
\\
\\
\text { Buyer ranked } \\
\text { No. } 1 \text { in question } \\
3.9\end{array}$ & $\begin{array}{l} \\
\text { FILL IN ONLY } \\
\text { IF farmer } \\
\text { supplied to any } \\
\text { supermarket but } \\
\text { not ranked it } \\
\text { No.1 }\end{array}$ & $\begin{array}{l}\text { FILL IN } \\
\text { ONLY } \\
\text { IF farmer } \\
\text { supplied to } \\
\text { any company } \\
\text { or institution } \\
\text { but not } \\
\text { ranked it No. } \\
1\end{array}$ \\
\hline Problem & & & \\
\hline 1. Cheating on price agreement & & & \\
\hline 2. Cheating on quality agreement & & & \\
\hline 3. Cheating on time of buying & & & \\
\hline 4. Cheating on the timing of payment & & & \\
\hline 5. Offers low price & & & \\
\hline 6. Cheating on damage/breakages & & & \\
\hline 7. Others (specify1) & & & \\
\hline 8. Others (specify2) & & & \\
\hline
\end{tabular}




\subsection{SECTION 5: INFORMATION ON CREDIT ACCESS AND SOCIAL NETWORKS}

5.1 Could you obtain credit if you need it for the purpose of operational expenses (e.g. buying fertilizer, paying for labor etc.)? $1=Y E S, 0=N O$

5.2 Could you obtain credit if you needed for the purpose of buying production assets (e.g. irrigation infrastructure)? $1=Y E S, 0=N O$

5.3 During the last $\mathbf{1 2}$ months, have you or any other household member received any credit to buy inputs, or received inputs on credit, for production of vegetables? $1=Y E S, 0=N O$

5.4 If yes, what were the sources and how much did you receive? (Include the value of inputs if inputs are provided on credit)

\begin{tabular}{|r|c|c|c|}
\hline Source & $\begin{array}{c}\text { Number of times } \\
\text { loan received }\end{array}$ & Total amount (Ksh) & $\begin{array}{c}\text { Person that received } \\
\text { loan (MEMID) }\end{array}$ \\
\hline 1. Input dealer & & & \\
\hline 2. NGO. & & & \\
\hline 3. Bank/cooperative society. & & & \\
\hline 4. Friends/relatives & & & \\
\hline $5 . \quad$ Moneylender. & & & \\
\hline $6 . \quad$ Other (specify) & & & \\
\hline
\end{tabular}

5.5 Are you or any other household member currently a member of any group or association?

$$
(1=Y E S ; 0=N O) \quad \text { (If no please go to question 5.8) }
$$

5.6 If yes what type of group do you/ household members belong to?

\begin{tabular}{|c|c|c|c|}
\hline Type of group & $\mathbf{1}=\mathbf{Y e s ;} \mathbf{0}=\mathbf{N o}$ & $\begin{array}{c}\text { Which household } \\
\text { member(s) are } \\
\text { involved? } \\
\text { (MEMID) }\end{array}$ & $\begin{array}{c}\text { How long have you } \\
\text { been a member of } \\
\text { this } \\
\text { group/association? } \\
\text { (in Months) }\end{array}$ \\
\hline 1. Producer group & & & \\
\hline 2. Farmers' cooperative society & & & \\
\hline 3. SACCO & & & \\
\hline 4. Women group & & & \\
\hline 5. Youth group & & & \\
\hline 6. Community welfare group & & & \\
\hline 7. Other (specify) & & & \\
\hline
\end{tabular}


5.7 What type of benefits/services do you receive from your group(s)?

\begin{tabular}{|c|c|c|}
\hline Benefits/Service & $\mathbf{I = Y E S ; ~} \mathbf{0}=\mathbf{N O}$ & $\begin{array}{c}\text { On a scale from 1 to } \\
5 \text { how big is the } \\
\text { help? } \\
\text { (Where 1 is very } \\
\text { small and 5 very } \\
\text { big) }\end{array}$ \\
\hline 1. $\quad$ Credit service & & \\
\hline 2. Input access & & \\
\hline 3. $\quad$ Training on crop production & & \\
\hline 4. Training on marketing & & \\
\hline 5. Marketing of farm produce & & \\
\hline 6. $\quad$ Welfare/social support & & \\
\hline 7. Other (specify): & & \\
\hline
\end{tabular}

5.8 Are you currently participating in AFMA/FC marketing activities? $(1=$ Yes; $0=N o)$

5.8.1 Since 2012, did you ever participate in any organized marketing activities? $(I=Y e s ; 0=N o)$ (If yes, mention

5.9 In the last $\mathbf{5}$ years, have you participated in "crop marketing days" organized by the district agricultural office? $\quad(1=$ Yes; $0=N o)$ 
6 SECTION 6: GENERAL HOUSEHOLD DEMOGRAPHIC INFORMATION

6.1 Household composition and income details: Please list all household members (All those who are under the care of household head in terms of food and shelter provision).

\begin{tabular}{|c|c|c|c|c|c|c|c|c|c|c|c|c|}
\hline $\begin{array}{l}1 . \\
\text { M } \\
\text { E } \\
\text { M } \\
\text { ID }\end{array}$ & $\begin{array}{c}2 \\
\text { Name of the HH member }\end{array}$ & $\begin{array}{c}3 \\
\text { Relationship } \\
\text { to HH head } \\
\text { (Use codes } \\
\text { below) }\end{array}$ & $\begin{array}{c}4 \\
\text { Gender } \\
M=1 ; \\
F=2\end{array}$ & $\begin{array}{c}5 \\
\text { Age in } \\
\text { years }\end{array}$ & $\begin{array}{c}6 \\
\text { Years of } \\
\text { formal } \\
\text { schooling }\end{array}$ & $\begin{array}{c}7 \\
\text { Marital } \\
\text { Status } \\
\text { (Use } \\
\text { codes }^{b} \\
\text { below) }\end{array}$ & $\begin{array}{c}8 \\
\text { How } \\
\text { many days } \\
\text { in the last } \\
7 \text { days } \\
\text { was this } \\
\text { person at } \\
\text { home? }\end{array}$ & $\begin{array}{c}9 \\
\text { Main } \\
\text { Occupation } \\
\text { (Use codes } \\
\text { below) }\end{array}$ & $\begin{array}{c}10 \\
\text { Number } \\
\text { of months } \\
\text { in the last } \\
12 \text { months } \\
\text { you have } \\
\text { been in } \\
\text { this occ? }\end{array}$ & $\begin{array}{c}11 \\
\text { Monthly } \\
\text { net } \\
\text { income } \\
\text { from } \\
\text { occupati } \\
\text { on } \\
\text { (Ksh). }\end{array}$ & $\begin{array}{c}12 \\
\text { Participate } \\
\text { in farm } \\
\text { work } \\
\\
1=Y E S ; \\
0=N O\end{array}$ & $\begin{array}{c}13 . \\
\text { Does this } \\
\text { person own } \\
\text { a } \\
\text { cellphone? } \\
1=Y E S ; \\
0=N O\end{array}$ \\
\hline 1 & & & & & & & & & & & & \\
\hline 2 & & & & & & & & & & & & \\
\hline 3 & & & & & & & & & & & & \\
\hline 4 & & & & & & & & & & & & \\
\hline 5 & & & & & & & & & & & & \\
\hline 6 & & & & & & & & & & & & \\
\hline 7 & & & & & & & & & & & & \\
\hline 8 & & & & & & & & & & & & \\
\hline 9 & & & & & & & & & & & & \\
\hline 10 & & & & & & & & & & & & \\
\hline 11 & & & & & & & & & & & & \\
\hline 12 & & & & & & & & & & & & \\
\hline
\end{tabular}




\begin{tabular}{|c|c|c|c|c|}
\hline \multicolumn{2}{|c|}{${ }^{\mathrm{a}}$ Relationship with household head } & \multicolumn{2}{|l|}{${ }^{{ }^{c} \text { Occupation }}$} & ${ }^{\mathrm{e}}$ Tribe \\
\hline \multirow{14}{*}{$\begin{array}{l}1=\text { Head } \\
2=\text { Spouse } \\
3=\text { Son/daughter } \\
4=\text { Father/mother } \\
5=\text { Sister/brother } \\
6=\text { Grandchildren } \\
7=\text { Grandparents } \\
8=\text { Step children } \\
9=\text { Step parent } \\
10 \\
=\text { Father/mother- } \\
\text { in-law }\end{array}$} & \multirow{6}{*}{$\begin{array}{l}11=\text { Sister/brother-in- } \\
\text { law } \\
12=\text { House girl } \\
13=\text { Farm laborers } \\
14=\text { Other Unrelated } \\
15=\text { Other relative }\end{array}$} & & 1=Kikuyu \\
\hline & & \multirow{2}{*}{\multicolumn{2}{|c|}{$\begin{array}{l}1=\text { Paid employment (civil servant, } \\
\text { working in private company etc) }\end{array}$}} & $2=\mathrm{Embu}$ \\
\hline & & & & $3=$ Meru \\
\hline & & \multicolumn{2}{|c|}{$2=$ Self-employed outside farm } & 4=Kamba \\
\hline & & \multirow{3}{*}{\multicolumn{2}{|c|}{$\begin{array}{l}3=\text { Working on household farm } \\
4=\text { Wage labor (working on other peoples } \\
\text { farms) }\end{array}$}} & $5=$ Kalenjin \\
\hline & & & & $6=$ Kisii \\
\hline & & & & $7=$ Luhya \\
\hline & ${ }^{b}$ Marital status & \multicolumn{2}{|c|}{-farm employment } & $8=$ Luo \\
\hline & $1=$ Married & \multicolumn{2}{|l|}{$6=\mathrm{St}$} & 9=Maasai \\
\hline & $2=$ Single & \multicolumn{2}{|c|}{$7=$ Other $($ Specify) } & $10=$ Other (specify) \\
\hline & $3=$ Divorced $/$ separated & \multicolumn{2}{|c|}{${ }^{\mathrm{d}}$ Religion } & \\
\hline & $4=$ Widow/widower & $1=$ Catholic & $2=$ Protestant & \\
\hline & & $3=$ Muslim_ & $4=$ Traditionalist & \\
\hline & & $5=$ No religion & $6=$ Others (specify) & \\
\hline
\end{tabular}

6.2 Kindly tell us the religion and tribe of the household head, spouse of the household head and the respondent (in case the respondent is not head or spouse to head)

\begin{tabular}{|l|l|l|l|}
\hline $\begin{array}{l}\text { MEMID (from } \\
\text { demog table }\end{array}$ & & $\begin{array}{l}\text { Tribe (Use } \\
\text { codes above) }\end{array}$ & $\begin{array}{l}\text { Religion } \\
\text { (Use codes } \\
\text { above) }\end{array}$ \\
\hline & Household head & & \\
\hline & Spouse to household head & & \\
& $\begin{array}{l}\text { Respondent (Fill only if respondent is not one of the } \\
\text { two above) }\end{array}$ & & \\
\hline
\end{tabular}

6.3 What was your household's income from the following sources during the past 12 months? (include the income of all household members listed in the table on page 29 exclude income already listed in the table on page 29)

\begin{tabular}{|c|c|c|c|}
\hline \multicolumn{2}{|c|}{ Income source } & \multirow{2}{*}{$\begin{array}{l}\text { Total } \\
\text { Income in } \\
\text { past } 12 \\
\text { months } \\
(K s h)\end{array}$} & \multirow{2}{*}{$\begin{array}{c}\text { Total cost } \\
\text { in this } \\
\text { activity } \\
\text { (Ksh) }\end{array}$} \\
\hline 1 & Income from hiring out machinery services to other farmers (ploughing etc.) & & \\
\hline 2 & Income from own non-agricultural businesses & & \\
\hline 3 & Pensions & & \\
\hline 4 & Remittances from family members/friends who do not live in the household & & \\
\hline 5 & Revenues from leasing out land & & \\
\hline 6 & Dividends (from shares, stocks, treasury bills etc.; not from coffee and tea) & & \\
\hline 7 & Other sources (please specify & & \\
\hline
\end{tabular}




\section{SECTION 7: HOUSEHOLD ACCESS TO SOCIOECONOMIC INFRASTRUCTURE}

7.1 Please indicate whether the following facilities are available in the village and answer whether or not you have access to them..

\begin{tabular}{|c|c|c|c|c|c|c|}
\hline Social facilities & $\begin{array}{l}\text { Available } \\
\text { in this } \\
\text { village } \\
1=Y E S \\
0=N O\end{array}$ & $\begin{array}{l}\text { Does your } \\
\text { household } \\
\text { have } \\
\text { access to } \\
\text { it? } \\
1=Y E S ; \\
0=N O\end{array}$ & $\begin{array}{l}\text { Distance } \\
\text { to the } \\
\text { nearest } \\
(\mathrm{km})\end{array}$ & $\begin{array}{l}\text { Most } \\
\text { frequently } \\
\text { used means of } \\
\text { transportation } \\
\text { (Use codes }{ }^{a} \\
\text { below) }\end{array}$ & $\begin{array}{l}\text { Travel time } \\
\text { with most } \\
\text { frequently } \\
\text { used means of } \\
\text { transportation } \\
\text { (in minutes) }\end{array}$ & $\begin{array}{l}\text { One } \\
\text { way } \\
\text { cost } \\
\text { to } \\
\text { travel } \\
\text { there } \\
\text { (Ksh) }\end{array}$ \\
\hline $\begin{array}{ll}1 . & \begin{array}{l}\text { Electricity } \\
\text { (KPLC) }\end{array} \\
\end{array}$ & & & & & & \\
\hline 2. Piped water system & & & & & & \\
\hline 3. Bank & & & & & & \\
\hline 4. Tarmac road & & & & & & \\
\hline 5. Matatu stage & & & & & & \\
\hline $\begin{array}{ll}6 . & \text { Public Transport } \\
\text { system }\end{array}$ & & & & & & \\
\hline $\begin{array}{l}\text { 7. Agric. extension } \\
\text { agent }\end{array}$ & & & & & & \\
\hline $\begin{array}{l}\text { 8. Agricultural input } \\
\text { market }\end{array}$ & & & & & & \\
\hline $\begin{array}{l}\text { 9. Agric. product } \\
\text { market }\end{array}$ & & & & & & \\
\hline 10. Health center & & & & & & \\
\hline $\begin{array}{l}\text { 11. Supermarket retail } \\
\text { outlet }\end{array}$ & & & & & & \\
\hline $\begin{array}{l}\text { 12. Local shopping } \\
\text { center }\end{array}$ & & & & & & \\
\hline $\begin{array}{l}\text { 13. Nearest supermarket } \\
\text { that buys fresh fruits } \\
\text { and vegetables from } \\
\text { farmers? }\end{array}$ & & & & & & \\
\hline $\begin{array}{l}\text { 14. Nearest wet market } \\
\text { (example: } \\
\text { Muthurua) }\end{array}$ & & & & & & \\
\hline $\begin{array}{l}\text { 15. Nearest place where } \\
\text { you can sell } \\
\text { vegetables? }\end{array}$ & & & & & & \\
\hline $\begin{array}{l}\text { 16. Nearest farmer that } \\
\text { owns means of } \\
\text { transportation for } \\
\text { vegetables }\end{array}$ & & & & & & \\
\hline
\end{tabular}

${ }^{a}$ Means of transport Codes

1=Bicycle; $\quad 2=$ =otorbike; 3=Car; 4=Walk; $\quad$ =Others (specify) 
8 SECTION 8: HOUSEHOLD ASSETS (Prompt for each item as listed below)

8.1 At present, how many/much of the following does this household own that are in usable/repairable condition? (Enumerator: For value per unit, ask for current value of items as they are in their current condition)

\begin{tabular}{|c|c|c|c|c|c|c|c|c|}
\hline & Agricultural asset & $\begin{array}{l}\text { Total } \\
\text { Quan- } \\
\text { tity }\end{array}$ & $\begin{array}{l}\text { Value } \\
\text { per Unit } \\
\text { (Ksh) }\end{array}$ & $\begin{array}{l}\text { If } \\
\text { Value/ } \\
\text { Unit not } \\
\text { known } \\
\text { Ask for } \\
\text { Total } \\
\text { Value }\end{array}$ & $\begin{array}{l}\text { Year when } \\
\text { asset was } \\
\text { acquired } \\
\text { If several } \\
\text { assets, write } \\
\text { the year of } \\
\text { the first }\end{array}$ & $\begin{array}{l}\text { Owner } \\
\text { (If more } \\
\text { than one } \\
\text { please } \\
\text { separate } \\
\text { by a } \\
\text { ""”; } \\
\text { name 2 } \\
\end{array}$ & $\begin{array}{l}\text { IF } \\
\text { MORE } \\
\text { THAN } \\
\text { ONE } \\
\text { OWNER: } \\
\text { Quantity } \\
\text { owned by } \\
\text { first/ } \\
\end{array}$ & $\begin{array}{l}\text { Who can } \\
\text { decide to } \\
\text { sell this } \\
\text { asset? (if } \\
\text { necessary } \\
\text { separate } \\
\text { by "y") }\end{array}$ \\
\hline & ASSET & QTY & $\begin{array}{l}\text { UVALU } \\
\text { E }\end{array}$ & $\begin{array}{c}\text { TOTVA } \\
\text { L }\end{array}$ & & MEMID & $\begin{array}{l}\text { MEMID/ } \\
\text { MEMID }\end{array}$ & \\
\hline 1 & Tractor & & & & & & & \\
\hline 2 & Car/Van & & & & & & & \\
\hline 3 & Pickup & & & & & & & \\
\hline 4 & Trailer & & & & & & & \\
\hline 5 & Motorcycle & & & & & & & \\
\hline 6 & Bicycle & & & & & & & \\
\hline 7 & Television & & & & & & & \\
\hline 8 & Radio & & & & & & & \\
\hline 9 & Mobile Phone & & & & & & & \\
\hline $\begin{array}{l}1 \\
0\end{array}$ & Refrigerator & & & & & & & \\
\hline $\begin{array}{l}1 \\
1\end{array}$ & Solar panels & & & & & & & \\
\hline $\begin{array}{l}1 \\
2\end{array}$ & Generator & & & & & & & \\
\hline $\begin{array}{l}1 \\
3\end{array}$ & Oxen & & & & & & & \\
\hline $\begin{array}{l}1 \\
4 \\
\end{array}$ & Chaf cutter & & & & & & & \\
\hline $\begin{array}{l}1 \\
5\end{array}$ & Ploughs for tractor & & & & & & & \\
\hline $\begin{array}{l}1 \\
6\end{array}$ & Animal traction plough & & & & & & & \\
\hline $\begin{array}{l}1 \\
7\end{array}$ & Cart & & & & & & & \\
\hline $\begin{array}{l}1 \\
8\end{array}$ & $\begin{array}{l}\text { Vegetable packing } \\
\text { shed }\end{array}$ & & & & & & & \\
\hline $\begin{array}{l}1 \\
9\end{array}$ & Water pump & & & & & & & \\
\hline $\begin{array}{l}2 \\
0\end{array}$ & Borehole & & & & & & & \\
\hline 2 & Well & & & & & & & \\
\hline $\begin{array}{l}2 \\
2 \\
\end{array}$ & Water tank & & & & & & & \\
\hline
\end{tabular}




\begin{tabular}{|l|l|l|l|l|l|l|l|l|}
\hline $\mathbf{2}$ & Drip irrigation system & & & & & & & \\
$\mathbf{3}$ & & & & & & & & \\
\hline $\mathbf{2}$ & Irrigation pipes & & & & & & \\
$\mathbf{4}$ & & & & & & & & \\
\hline $\mathbf{2}$ & Sprinkler & & & & & & & \\
\hline $\mathbf{2}$ & (Gas) stove & & & & & & \\
$\mathbf{6}$ & & & & & & & \\
\hline $\mathbf{2}$ & Furniturefor & & & & & \\
$\mathbf{7}$ & agriculture & & & & & & \\
$\mathbf{2}$ & Greenhouse & & & & & & & \\
\hline $\mathbf{2}$ & Biogas digesters & & & & & & & \\
$\mathbf{9}$ & & & & & & & & \\
\hline $\mathbf{3}$ & Other ( & & & & & & & \\
$\mathbf{0}$ & & & & & & & & \\
\hline
\end{tabular}


8.2 How is land ownership divided over your household?

\begin{tabular}{|c|c|c|c|c|c|c|}
\hline & $\begin{array}{l}\text { a) } \\
\text { MEMID } \\
\text { of owner }\end{array}$ & $\begin{array}{l}\text { b) } \\
\text { Size }\end{array}$ & $\begin{array}{l}\text { c) } \\
\text { Unit } \\
\left(1=\text { acres, } 2=m^{2},\right. \\
\left.3=H a, 4=\text { feet }^{2}\right)\end{array}$ & $\begin{array}{l}\text { d) } \\
\text { What is the } \\
\text { current } \\
\text { value (Ksh) }\end{array}$ & $\begin{array}{l}\text { e) } \\
\text { Can this person } \\
\text { decide to sell this } \\
\text { land? } \\
(1 \text { if "Yes"; } 0 \text { if "No"; } \\
\text { If "No" go to f }) \text { ) }\end{array}$ & $\begin{array}{l}f) \\
\text { Who can decide to } \\
\text { sell this land? } \\
\text { (MEMID or specify) }\end{array}$ \\
\hline 1) & & & & & & \\
\hline 2) & & & & & & \\
\hline 3) & & & & & & \\
\hline
\end{tabular}

\section{SECTION 9: SHOCKS}

9.1 Over the past three years, was your household negatively affected by any of the following events or developments? Please rank the 3 most severe problems experienced.

\begin{tabular}{|c|c|c|c|c|c|}
\hline & \multirow[t]{3}{*}{$\begin{array}{l}\text { PLEASE ANSWER THE FOLLOWING } \\
\text { QUESTIONS ACCORDINGLY }\end{array}$} & \multicolumn{3}{|c|}{$\begin{array}{l}\text { The household was }[\ldots] \text { affected } \\
\text { by }[\ldots]\end{array}$} & \multirow{3}{*}{$\begin{array}{l}\text { Ranking } \\
\text { of shocks } \\
\text { (From } 1 \\
\text { to } 3 ; \\
\text { Starting } \\
\text { with } 1 \text { for } \\
\text { worst) }\end{array}$} \\
\hline & & Severely & Slightly & Not at all & \\
\hline & & $\begin{array}{l}(1=\text { Yes } \\
0=N o)\end{array}$ & $\begin{array}{l}(1=\text { Yes } \\
0=N o)\end{array}$ & $\begin{array}{l}(1=\text { Yes } \\
0=N o)\end{array}$ & \\
\hline 1 & Drought & & & & \\
\hline 2 & Too much rain or flood & & & & \\
\hline 3 & Erosion and gully formation & & & & \\
\hline 4 & Frosts or hailstorm & & & & \\
\hline 5 & $\begin{array}{l}\text { Pests or diseases that affected crops before they } \\
\text { were harvested }\end{array}$ & & & & \\
\hline 6 & Pests or diseases that led to storage losses & & & & \\
\hline 7 & Theft of crops & & & & \\
\hline 8 & Loss of livestock (death, theft, illness) & & & & \\
\hline 9 & Fire & & & & \\
\hline 10 & Death of male household head & & & & \\
\hline 11 & Death of female household head & & & & \\
\hline 12 & Death of other person & & & & \\
\hline 13 & Illness of male household head & & & & \\
\hline
\end{tabular}




\begin{tabular}{|c|l|l|l|l|l|}
\hline 14 & Illness of female household head & & & & \\
\hline 15 & Illness of other person & & & & \\
\hline 16 & Loss of regular job of a household member & & & & \\
\hline 17 & $\begin{array}{l}\text { Divorce or abandonment of household head by } \\
\text { partner }\end{array}$ & & & & \\
\hline 18 & Family member left for other reasons & & & & \\
\hline 19 & $\begin{array}{l}\text { Other } \\
\text { (specify }\end{array}$ & & & & \\
\hline
\end{tabular}

10 SECTION 10: CHARACTERISTICS OF MAIN HOUSE

(ENUMERATOR: PLEASE OBSERVE AND ASK ABOUT THE FOLLOWING)

10.1 What is the roofing material of the main house?

ROOF

(1=grass /makuti $\quad 2=$ iron sheet $\quad 3=$ tiles $\quad 4=$ other, specify

10.2 What is the wall material of the main house?

WALL

$(1=$ mud $\quad 2=$ bricks/stones $3=$ iron sheet $\quad 4=$ wood $5=$ plastered $\quad 6=$ other, specify

10.3 What is the floor material of the main house?

FLOOR

$$
(1=\text { earth } \quad 2=\text { cement } \quad 3=\text { wood } \quad 4=\text { tiles } \quad 5=\text { other } \text { specify }
$$

10.4 What is the mode of ownership of the main house?

HSEOWN

$$
(1=\text { owned } \quad 2=\text { rented } \quad 3=\text { owned by relative } \quad 4=\text { other }, \text { specify }
$$

10.5 What type of toilet do you use?

TOILET

$$
\text { (1=pit latrine } \quad 2=\text { bush } \quad 3=\text { flush toilet } \quad 4=\text { other }, \text { specify }
$$

10.6What is the main source of water for domestic use during the wet-season?

MAINWET

Distance (minutes walking)

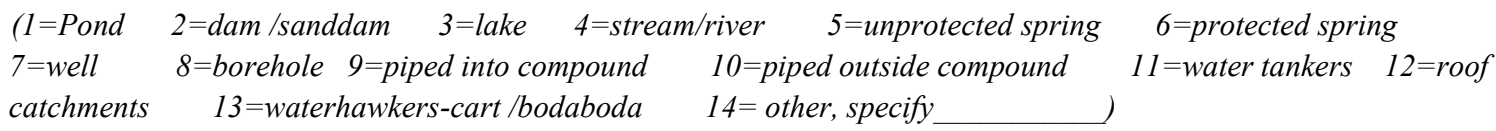

10.7What is the main source of water for domestic use during the dry-season?

MAINDRY

Distance (minutes walking) 


\begin{tabular}{|c|c|c|c|c|}
\hline & $2=d a m /$ sanddam & $4=$ stream/river & $5=$ unprotected spring & $6=$ protected spring \\
\hline & $8=$ borehole $\quad 9=p$ & ed into compound $\quad 10=p$ & iped outside compound & $11=$ water tankers \\
\hline & $13=w$ & kers-cart /bodaboda & $14=$ other, specify & \\
\hline
\end{tabular}

10.8What is your main cooking fuel?

COOKFUEL

$\begin{aligned} & (1=\text { electricity } 2=\text { paraffin } \\ & \text { specify }\end{aligned}$
S=firewood $\quad 4=$ gas $\quad 5=$ charcoal $\quad 6=$ solar power $\quad 7=$ other,

10.9What is your main source of lighting?

$(1=$ electricity $\quad 2=$ pressure lamp $\quad 3=$ tin lamp

$7=$ other, specify
LITFUEL

$4=$ fuel wood $\quad 5=$ lantern

$6=$ solar power 


\section{SECTION 11: HOUSEHOLD NUTRITION KNOWLEDGE AND AWARENESS}

11.1 Has any member of this household ever been trained /received any information on the nutritive benefits of consuming different type foods? $(1=$ Yes; $0=$ No) NTRAIN

11.2 If yes, what were they trained on/ got information on?

TRAIN1

TRAIN2

TRAIN3

TRAIN4

11.3 What was the source of the training/information?

$\begin{array}{llll}\begin{array}{l}\text { 1= From } \text { a radio } \\ \text { program }\end{array} & \begin{array}{c}\text { 4= Local leader } \\ \text { 2= From } \text { a TV program }\end{array} & 7=\text { From a neighbor } & 9=\text { From supermarket representative } \\ 3=\text { Church } & 6=\text { From Hospital } & \text { 10=Others } \text { (specify) } \\ \text { TSOURCE1 } & \text { TSOURCE2 } & \text { TSOURCE3 } & \text { TSOURCE4 }\end{array}$

12. SECTION 12: HOUSEHOLD FOOD CONSUMPTION IN THE LAST 7 DAYS (Enumerators: Please ask the following questions to the person who is mainly responsible for preparing food)

12.1 In the past seven days indicate how much of the following food items your household consumed and the prices in Kshs (This is for all food consumed in the household, including own-produced, bought, gifts and from food aid program, by all the people listed on demographic table on page 29 before. INCLUDE food prepared at home but eaten outside. EXCLUDE meals prepared outside the home) 


\begin{tabular}{|c|c|c|c|c|c|c|c|c|c|}
\hline & $\begin{array}{l}\text { Food Items consumed in the } \\
\text { past } 7 \text { DAYS }\end{array}$ & $\begin{array}{l}\text { How much in } \\
\text { total did your } \\
\text { household } \\
\text { consume } \\
\text { during the } \\
\text { last } 1 \text { week? }\end{array}$ & $\begin{array}{l}\text { Unit of } \\
\text { quantities } \\
\text { consumed } \\
\text { (Use codes } \\
\text { below) }\end{array}$ & $\begin{array}{l}\text { Total value of } \\
\text { consumption } \\
\text { in Kshs }\end{array}$ & & $\begin{array}{l}\text { Food Items consumed in } \\
\text { the past } 7 \text { DAYS }\end{array}$ & $\begin{array}{l}\text { How much in } \\
\text { total did your } \\
\text { household } \\
\text { consume } \\
\text { during the } \\
\text { last } 1 \text { week? }\end{array}$ & $\begin{array}{l}\text { Unit of } \\
\text { quantities } \\
\text { consumed } \\
\text { (Use codes } \\
\text { below) }\end{array}$ & $\begin{array}{l}\text { Total value of } \\
\text { consumption in } \\
\text { Kshs }\end{array}$ \\
\hline & Staple foods & & & & & Vegetables & & & \\
\hline 1 & Cassava Tuber & & & & 30 & Okra & & & \\
\hline 2 & Cassava flour & & & & 31 & \begin{tabular}{|l|} 
Tomato \\
\end{tabular} & & & \\
\hline 3 & Cassava chips & & & & 32 & Pepper & & & \\
\hline 4 & Yam Tuber & & & & 33 & Onion & & & \\
\hline 5 & Yam flour & & & & 34 & Carrot & & & \\
\hline 6 & Yam chips & & & & 35 & Egg plant (biringanya) & & & \\
\hline 7 & Orangefleshed sweet potato & & & & 36 & Cabbage & & & \\
\hline 8 & Other sweetpotato & & & & 37 & Cucumber & & & \\
\hline 9 & Sweet potato chips & & & & 38 & Pumpkin & & & \\
\hline 10 & Irish potato & & & & 39 & Butternut & & & \\
\hline 11 & Irish potato chips & & & & 40 & Spinach & & & \\
\hline 12 & Arrowroots & & & & 41 & Kales (Sukuma wiki) & & & \\
\hline 13 & Maize green & & & & 42 & Amarantha leaves (terere) & & & \\
\hline 14 & Maize grain & & & & 43 & Pumpkin leaves & & & \\
\hline 15 & Maize flour & & & & 44 & Sweet potato leaves & & & \\
\hline 16 & Sorghum grain & & & & 45 & Black night shade & & & \\
\hline 17 & Sorghum Flour & & & & 46 & Cow pea leaves & & & \\
\hline 18 & Millet grain & & & & 47 & Stinging nettle (thabai) & & & \\
\hline 19 & Millet flour & & & & & Other vegetables (specifv) & & & \\
\hline 20 & Brown rice & & & & 48 & & & & \\
\hline 21 & White rice & & & & 49 & & & & \\
\hline 22 & Wheat grain & & & & 50 & & & & \\
\hline 23 & Wheat flour brown & & & & & & & & \\
\hline 24 & Wheat flour white & & & & & Nuts and Pulses & & & \\
\hline \multirow[t]{2}{*}{25} & Cooking banana & & & & 51 & Beans dry & & & \\
\hline & Other staple foods & & & & 52 & Beans fresh & & & \\
\hline 26 & & & & & 53 & Black beans (Niahi) & & & \\
\hline 27 & & & & & 54 & Green grams (Ndengu) & & & \\
\hline 28 & & & & & 55 & Soybean & & & \\
\hline \multirow[t]{4}{*}{29} & & & & & 56 & Peas (incl cowpea, pigeon & & & \\
\hline & & & & & 57 & Lentils & & & \\
\hline & & & & & 58 & Groundnut & & & \\
\hline & & & & & 59 & Cashew nut (korosho) & & & \\
\hline 60 & Soya meat (e.g. Sossi) & & & & 89 & Pork Sausage & & & \\
\hline
\end{tabular}




\begin{tabular}{|c|c|c|c|c|c|c|c|c|c|}
\hline & $\begin{array}{l}\text { Food Items consumed in the } \\
\text { past } 7 \text { DAYS }\end{array}$ & $\begin{array}{l}\text { How much in } \\
\text { total did your } \\
\text { household } \\
\text { consume } \\
\text { during the } \\
\text { last } 1 \text { week? }\end{array}$ & $\begin{array}{l}\text { Unit of } \\
\text { quantities } \\
\text { consumed } \\
\text { (Use codes } \\
\text { below) }\end{array}$ & $\begin{array}{l}\text { Total value of } \\
\text { consumption } \\
\text { in Kshs }\end{array}$ & & $\begin{array}{l}\text { Food Items consumed in } \\
\text { the past } 7 \text { DAYS }\end{array}$ & $\begin{array}{l}\text { How much in } \\
\text { total did your } \\
\text { household } \\
\text { consume } \\
\text { during the } \\
\text { last } 1 \text { week? }\end{array}$ & $\begin{array}{l}\text { Unit of } \\
\text { quantities } \\
\text { consumed } \\
\text { (Use codes } \\
\text { below) }\end{array}$ & $\begin{array}{l}\text { Total value of } \\
\text { consumption in } \\
\text { Kshs }\end{array}$ \\
\hline 61 & Soybean flour & & & & 90 & Eggs (pieces) with yolk & & & \\
\hline & Other pulses and nuts & & & & 91 & Eggs without yolk & & & \\
\hline 62 & & & & & 92 & Liver (from any animal) & & & \\
\hline \multirow[t]{3}{*}{63} & & & & & 93 & Offals (matumbo) & & & \\
\hline & & & & & & Other meats & & & \\
\hline & Fruits & & & & 94 & & & & \\
\hline 64 & Orange & & & & 95 & & & & \\
\hline 65 & Ripe mango & & & & 96 & & & & \\
\hline 66 & Ripe pawpaw & & & & 97 & & & & \\
\hline 67 & Pineapple & & & & & Dairy products & & & \\
\hline 68 & Apple & & & & 98 & Milk (cow/goat milk) & & & \\
\hline 69 & Coconut & & & & 99 & Powdered milk & & & \\
\hline 70 & Guava & & & & 100 & Sour milk (mala) & & & \\
\hline 71 & Ripe bananas & & & & 101 & Cheese & & & \\
\hline 72 & Melon & & & & 102 & Yoghurt & & & \\
\hline 73 & Sugar cane & & & & 103 & Ice cream & & & \\
\hline \multirow[t]{2}{*}{74} & Avocado & & & & & Other dairy product & & & \\
\hline & Other fruits & & & & 104 & & & & \\
\hline 75 & & & & & 105 & & & & \\
\hline 76 & & & & & 106 & & & & \\
\hline \multirow[t]{2}{*}{77} & & & & & & Beverages & & & \\
\hline & Meat and animal Products & & & & 107 & Cocoa powder & & & \\
\hline 78 & Cow meat & & & & 108 & Tea (leaves) & & & \\
\hline 79 & Goat/ Sheep meat & & & & 109 & Coffee (powder) & & & \\
\hline 80 & Pork & & & & 110 & Milo powder & & & \\
\hline 81 & Chicken & & & & 111 & Soya powder & & & \\
\hline 82 & Bush meat (Game meat) & & & & 112 & Drinking chocolate & & & \\
\hline 83 & Turkey (bata mzinga) & & & & & Other beverages & & & \\
\hline 84 & Fish & & & & 113 & & & & \\
\hline 85 & Snail & & & & 114 & & & & \\
\hline 86 & Crabs & & & & 115 & & & & \\
\hline 87 & Chicken sausage & & & & 116 & & & & \\
\hline \multirow[t]{2}{*}{88} & Beef sausage & & & & & & & & \\
\hline & Drinks & & & & 145 & Butter & & & \\
\hline 117 & Soft drinks (coke/fanta/etc) & & & & 146 & Margarine & & & \\
\hline
\end{tabular}




\begin{tabular}{|c|c|c|c|c|c|c|c|c|c|}
\hline 118 & $\begin{array}{l}\text { Food Items consumed in the } \\
\text { past } 7 \text { DAYS }\end{array}$ & $\begin{array}{l}\text { How much in } \\
\text { total did your } \\
\text { household } \\
\text { consume } \\
\text { during the } \\
\text { last } 1 \text { week? }\end{array}$ & $\begin{array}{l}\text { Unit of } \\
\text { quantities } \\
\text { consumed } \\
\text { (Use codes } \\
\text { below) }\end{array}$ & $\begin{array}{l}\text { Total value of } \\
\text { consumption } \\
\text { in Kshs }\end{array}$ & 147 & Sunflower oil & $\begin{array}{l}\text { How much in } \\
\text { total did your } \\
\text { household } \\
\text { consume } \\
\text { during the } \\
\text { last } 1 \text { week? }\end{array}$ & $\begin{array}{l}\text { Unit of } \\
\text { quantities } \\
\text { consumed } \\
\text { (Use codes } \\
\text { below) }\end{array}$ & $\begin{array}{l}\text { Total value of } \\
\text { consumption in } \\
\text { Kshs }\end{array}$ \\
\hline 119 & Apple juice & & & & 148 & Cooking fat & & & \\
\hline 120 & Pineapple juice & & & & 149 & Other oil(specify) & & & \\
\hline 121 & Other juice (concentrates) & & & & 150 & & & & \\
\hline 122 & Local beer & & & & 151 & & & & \\
\hline 123 & Bottled beer & & & & 152 & & & & \\
\hline 124 & Other beer & & & & 153 & & & & \\
\hline \multirow[t]{2}{*}{125} & Wine & & & & & Snacks & & & \\
\hline & Other drinks & & & & 154 & Bread & & & \\
\hline 126 & & & & & 155 & Biscuit/cookies & & & \\
\hline 127 & & & & & 156 & Popcorn & & & \\
\hline \multirow[t]{2}{*}{128} & & & & & 157 & Cakes & & & \\
\hline & Condiments and spices & & & & & Other snacks & & & \\
\hline 129 & Salt & & & & 158 & & & & \\
\hline 130 & Curry & & & & 159 & & & & \\
\hline 131 & Ginger (tangawizi) & & & & 160 & & & & \\
\hline \multirow[t]{2}{*}{132} & Ketchup, Tomato sauce & & & & & & & & \\
\hline & Other spices & & & & & & & & \\
\hline \multicolumn{10}{|c|}{\begin{tabular}{l|l}
133 & \\
\end{tabular}} \\
\hline \multicolumn{10}{|l|}{134} \\
\hline \multicolumn{10}{|l|}{135} \\
\hline \multicolumn{10}{|l|}{136} \\
\hline & Sugar and sweets & & & & & & & & \\
\hline 138 & Sugar & & & & & & & & \\
\hline 139 & \begin{tabular}{|l} 
Chocolate \\
\end{tabular} & & & & & & & & \\
\hline 140 & Other sweet & & & & & & & & \\
\hline & Fat and Oil & & & & & & & & \\
\hline 141 & Red palm oil & & & & & & & & \\
\hline 142 & Groundnut oil & & & & & & & & \\
\hline 143 & Coconut oil & & & & & & & & \\
\hline 144 & Sheer butter oil & & & & & & & & \\
\hline & & & & & & & & & \\
\hline
\end{tabular}




\begin{tabular}{|c|c|c|c|c|c|c|c|}
\hline \multicolumn{8}{|c|}{ UNIT CODES } \\
\hline $1=$ LITER & $3=\mathrm{KGS}$ & $5=5 \mathrm{KG} . \mathrm{BAG}$ & $\begin{array}{l}7=50 \mathrm{KG} . \\
\mathrm{BAG}\end{array}$ & $9=\mathrm{DEBE}$ & $\begin{array}{l}11= \\
\text { PIECE/NUMBER }\end{array}$ & $\begin{array}{l}13=1 / 4 \\
\text { KG TIN }\end{array}$ & $\begin{array}{l}15=1 \mathrm{KG} \text { TIN } \\
16=\text { BUNDLES }\end{array}$ \\
\hline 2= MILILITER & $\begin{array}{l}4= \\
\text { GRAMS }\end{array}$ & $\begin{array}{l}6=25 \mathrm{KG} . \\
\text { BAG }\end{array}$ & $\begin{array}{l}8=90 \mathrm{KG} . \\
\text { BAG }\end{array}$ & $\begin{array}{l}10=\mathrm{BUNCH} \\
\text { (Bananas) }\end{array}$ & $\begin{array}{l}12= \\
\text { GOROGORO }\end{array}$ & $\begin{array}{l}14=1 / 2 \\
\text { KG TIN }\end{array}$ & $\begin{array}{l}17=\text { Cup (15) } \\
18=\text { Others } \\
\text { Specify }\end{array}$ \\
\hline
\end{tabular}

12.2 Food consumed by household members away from home in the last 7 days (eg in schools, in restaurants, during ceremony etc), Household members are the people listed in page 29.

\begin{tabular}{|c|c|c|c|c|c|c|c|}
\hline \multirow{2}{*}{$\begin{array}{l}\text { Mem } \\
\text { ID }\end{array}$} & \multirow{2}{*}{$\begin{array}{l}\text { Type of food } \\
\text { eaten }\end{array}$} & \multirow{2}{*}{$\begin{array}{c}\text { No. } \\
\text { of } \\
\text { times }\end{array}$} & \multicolumn{4}{|c|}{ Components of the food } & \multirow{2}{*}{$\begin{array}{l}\text { Total } \\
\text { value } \\
\text { in } \\
\text { Kshs }\end{array}$} \\
\hline & & & $\begin{array}{l}\text { Component } \\
1\end{array}$ & $\begin{array}{l}\text { Component } \\
2\end{array}$ & $\begin{array}{l}\text { Component } \\
3\end{array}$ & $\begin{array}{l}\text { Component } \\
4\end{array}$ & \\
\hline & & & & & & & \\
\hline & & & & & & & \\
\hline & & & & & & & \\
\hline & & & & & & & \\
\hline & & & & & & & \\
\hline & & & & & & & \\
\hline & & & & & & & \\
\hline & & & & & & & \\
\hline & & & & & & & \\
\hline & & & & & & & \\
\hline & & & & & & & \\
\hline & & & & & & & \\
\hline & & & & & & & \\
\hline & & & & & & & \\
\hline
\end{tabular}




\section{SECTION 13: CHOICE EXPERIMENT-ASSESSING FARMERS' PREFERENCES FOR CONTRACT DESIGN ATTRIBUTES}

We are conducting a choice experiment that focuses on the issue of contracts as one of the factors that influence farmers' participation in markets. We will therefore assess farmers' preference for various contracts (oral or written) and their corresponding features. The responses you give here will be confidential and will not influence your chances to supply any particular buyer.

We will present three different contract options with features that characterize traditional markets and high value markets such as supermarkets, restaurants and institutions. One option will represent features of traditional markets while the other two will represent high value markets.

The traditional market is characterized by sales at farm gate, usually at lower prices, immediate cash payments, with sales always possible at any time, and the produce usually sold as harvested. High value markets on the other hand are characterized by higher prices of produce sold according to pre-specified contractual agreements, written or oral, to supply produce of designated forms (usually cleaned and sorted), at designated times, places, and periods of payment (could be delayed by up to two weeks) for example, contracts with supermarkets, restaurants and schools .

\section{[Explain the pictures/contract features at this point to the farmer]}

Then explain this way:

"I am about to present to you three market options and I request you to choose your most preferred option. If you had an option to supply vegetables to any of the following three markets, which one would you prefer to supply?"

[Read the 3 options in each of the 6 choice cards sequentially at a time and record the response in the table below]

\begin{tabular}{|l|l|l|l|l|}
\hline \multicolumn{1}{|c|}{ Choices/profiles } & \multirow{2}{*}{ Choice card No. } & \multicolumn{3}{c|}{ OPTIONS } \\
\cline { 3 - 5 } & & Option 1 & Option 2 & Option 3 \\
\hline Choice 1 & & & & \\
\hline Choice 2 & & & & \\
\hline Choice 3 & & & & \\
\hline Choice 4 & & & & \\
\hline Choice 5 & & & & \\
\hline Choice 6 & & & & \\
\hline
\end{tabular}

Thank you for your time and patience!

END TIME: : 


\section{Choice Experiment Protocol}

We are conducting a study to better understand farmers' preferences for vegetable marketing contracts with supermarkets. For this purpose, we are carrying out a small experiment, where you are asked to choose between different options to market your vegetables. The options will differ in terms of prices and other contract conditions. Out of three possible options, you should always choose the one that you find most attractive. This is only an experiment, that is, the choices you make here will not affect your vegetable marketing conditions in reality. Regardless of your answers, you will not have any economic gains or losses. Nevertheless, we kindly ask you to consider the options seriously and make your choice as if this were a real marketing situation. This will help us to better understand farmers' preferences and constraints. Results from this research can possibly help to make some general recommendations about how to improve contract conditions in the future.

Before starting the experiment, let me explain the main contract attributes in terms of which marketing options to choose from will differ. We consider five different contract attributes.

The first contract attribute refers to the price the buyer will pay per bundle of leafy vegetables (kale). Prices in the different marketing options will range from 10 shillings per bundle, which is the average price in traditional spot markets (when you sell to buyers without a contract), to 20 shillings in certain contractual arrangements.

The second contract attribute is the place of sale, where we consider three possibilities:

- "Farm gate" means sales to buyers who pick up the produce from your farm, so that you would not incur any transportation costs.

- "Nearby market" means that vegetables would have to be delivered to a specified location in the closest town. You would have to organize the transport and carry the cost.

- "Buyers' premise" means that vegetables would have to be delivered to a specified supermarket store in Nairobi (or any other institution in Nairobi purchasing vegetables under contract). You would have to organize the transport and carry the cost.

The third contract attribute is the form of sale, where we consider two possibilities: 
- "Sold as harvested" means that you could sell the vegetables as harvested from the plot without any cleaning or sorting, as is common in traditional markets without contract.

- "Sold in washed and sorted form" means that you would have to clean and sort the vegetables ready for retail sales, as is common in supermarket contracts.

The fourth contract attribute is the timing of sale, where we consider three possibilities:

- "Sales possible at any time" means that you could sell whenever you have harvested, without any specified time schedule, as is common in traditional markets without contract.

- "Sales at times specified in the contract" means that you would have to sell your vegetables according to a time schedule specified in the contract.

- "Sales based on phone orders by buyer" means that the supermarket (or other contractor) would always call you a few days prior to required delivery. That is, the contract would not specify exact delivery dates, but you would have to wait for phone orders.

The fifth contract attribute is the payment mode, where we consider five possibilities:

- "Payment immediate, based on quantity delivered" means that you would get the payment on the spot, without any delay, for the quantity handed over to the buyer, as is common in traditional markets without contract.

- "Payment delayed, based on quantity delivered" means that you would get the payment up to two weeks after product delivery for the quantity handed over to the buyer.

- "Payment delayed, based on quantity buyer sold to customers, physically verifiable by farmer" means that you would get the payment up to two weeks after product delivery, but possibly not for the total quantity handed over to the buyer. Instead, the buyer would only pay you for the quantity that he/she was able to sell to customers. That is, you would not be paid for the part of your delivery that remains on the supermarket shelve for several days without being purchased by customers. Physical verification means that you could inspect and take back the unsold part of your delivery several days later. 
- "Payment delayed, based on quantity buyer sold to customers, verifiable by farmer through barcoding system" means that you would get the payment up to two weeks after product delivery and would only be paid for the quantity that the supermarket was able to sell to its customers. Verifiable through barcoding system means that you would get a computer-generated slip with sold and unsold quantities recorded by a barcode scanner. This barcoding system would replace the possibility of physical inspection.

- "Payment delayed, based on quantity buyer sold to customers, not verifiable by farmer" means that you would get the payment up to two weeks after product delivery and would only be paid for the quantity that the supermarket was able to sell to its customers. You would have no option to verify how much of your delivery was actually sold to customers but would have to rely on the statements made by the supermarket.

In the following, I will present you with choice cards, where each card shows three marketing options from which you should choose your preferred one. The first two options always reflect contracts with variations in the contract attributes that we just discussed. The third option always reflects the situation in the traditional market without contract. Please consider the options carefully and choose the one that you feel would be the most lucrative for you to sell your vegetables.

I will sequentially present six choice cards to you, so you will be asked to make six choices, one for every card. Please consider each choice card independently from previous cards, that is, for each choice please only consider the three options on the present card and do not feel influenced by possibly better or worse options you saw on a previous card.

Now we start (example from Figure 2 in the main article text):

Option 1: This involves a contract in which you get 20 shillings/bundle of vegetables. The vegetables can be sold to the buyer at the farm gate. You can sell in the form as harvested, no cleaning and sorting is required. But you can only sell upon receiving phone call orders from the buyer. Payment is delayed by up to 2 weeks, and you will only be paid for the quantity that the buyer was actually able to sell to its customers, which you can verify through a bar code system. 
Option 2: This involves a contract in which you get 14 shillings/bundle of vegetables. The vegetables can be sold to the buyer at the farm gate. But you have to wash and sort the vegetables before handing them over to the buyer. The timing of sales is specified in the contract with concrete dates for each transaction. Payment is delayed by up to 2 weeks, and you will only be paid for the quantity that the buyer was actually able to sell to its customers, which you can verify physically by inspecting the unsold quantity.

Option 3: This reflects a typical traditional marketing situation without a contract. You get 10 shillings/bundle of vegetables. The vegetables can be sold to the buyer at the farm gate. You can sell in the form as harvested, no cleaning and sorting is required. You can sell at any time, and will receive immediate payment for the quantity handed over to the buyer.

Out of these three options, please choose your preferred one.

(This continues six times with randomly assigned choice cards for each farmer). 


\section{List of Publications and Presentations}

\section{Referred Conference Papers}

Ochieng, D.O., Veettil, P.C., Qaim, M., 2016. Farmers' Preference for Supermarket Contracts in Kenya. Selected paper accepted for oral presentation at the 2016 Agricultural \& Applied Economics Association Annual Meeting, Boston, Massachusetts, July 31-August 2.

Ochieng, D.O. Supermarket Contracts, Income and Changing Diets of Rural Farmers: Panel Data Evidence from Kenya. Selected paper accepted for oral presentation at the 2017 GlobalFood Symposium. Georg-August University of Goettingen, Germany, April 28- 29.

\section{Refereed publications}

Ochieng, D.O., Veettil, P.C., Qaim, M., 2017. Farmers' preferences for supermarket contracts in Kenya. Food Policy 68, 100-111. 


\section{Curriculum Vitae}

\section{Personal data}

Name: $\quad$ OCHIENG, Dennis Otieno

Date of Birth: May 7, 1985

Place of birth: Migori, Kenya

Nationality: Kenya

\section{Education}

6/2013 - present

$\mathrm{PhD}$ student, Department of Agricultural Economics and Rural Development, Faculty of Agricultural Science, University of Goettingen, Germany; RTG 1666 GlobalFood.

8/2008 - $2010 \quad$ Master of Agricultural and Applied Economics, Egerton University.

01/2005 - 7/2008 Bachelor of Science (Agricultural Economics), Egerton University.

\section{Working experience}

4/2014 - present

Department of Agricultural Economics and Rural Development, Faculty of Agricultural Sciences, University of Goettingen, Germany. RTG 1666 GlobalFood. Research Associate.

$2011-3 / 2014$

United Nations World Food Program /African Economic Research Consortium. Data Analyst. Main duties: Monitor and evaluate the implementation of the Purchase for Progress (P4P) project on linking smallholder farmers to markets in the Africa, Central America and Asian countries.

8/2008-2010 Department of Agricultural Economics and Business Management, Egerton University/CIAT CSO DioBass Project, South Kivu, The Democratic Republic of Congo, Masters student, Research assistant.

2003 - $2004 \quad$ Upendo Women Group, Homa-Bay. Volunteer Community Mobilizer. Main duties: Mobilizing communities for HIV testing and counselling, conduct participatory rural project appraisals for , training community groups on entrepreurship. 